\title{
EFEITO DA POLUIÇÃO DO AR NA \\ CARCINOGENESE DE CAMUNDONGOS
}

Fernanda Alves Cangerana Pereira

São Paulo

2005

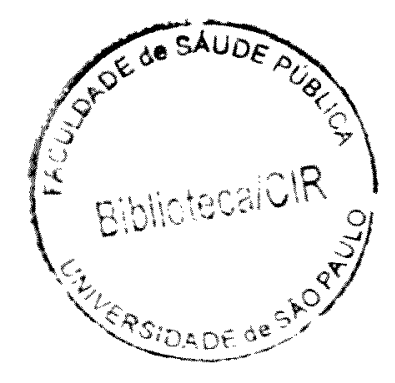




\section{EFEITO DA POLUIÇÃO \\ DO AR NA CARCINOGENESE \\ DE CAMUNDONGOS}

\section{Fernanda Alves Cangerana Pereira}

Tese de Doutorado apresentada ao Departamento de Saúde Ambiental da Faculdade de Saúde Pública da Universidade de São Paulo para obtenção do Grau de Doutor.

Área de Concentração:

Saúde Ambiental.

Orientadores: Prof. Dr. Paulo Hilário Nascimento Saldiva e Prof. Dr. João Vicente de Assunção

São Paulo 


$$
45919 / 2005 \text { doe }
$$

Autorizo, exclusivamente para fins acadêmicos e científicos, a reprodução total ou parcial desta tese, por processos fotocopiadores.

Assinatura:

Data: 
AGRADEÇO À DEUS PELA POSSIBILIDADE DE REALIZAR ESTE ESTUDO DE DOUTORADO. PELA PERSISTÊNCIA QUE FAZ COM QUE EU REALIZE. POR TODAS AS COISAS BOAS DE MINHA VIDA QUE TORNAM AS SEGUNDASFEIRAS TÃo AGRADÁVEIS. POR TODOS OS MOMENTOS DIFÍCEIS QUE ME ENSINARAM A SER COMPREENSIVA COM AS OUTRAS PESSOAS. 


\section{Dedicatória:}

Dedico esta tese:

aos meus pequenos vertebrados, Cecília e Vicente, que ao despertarem em mim a fêmea de mamífero, lapidaram minha alma para enxergar a criança presente em cada ser humano;

ao meu melhor amigo Regis, pelos incontáveis momentos felizes, pelas conversas que não acabam nunca, por estar sempre ao meu lado, por eu ser tão amada e feliz.

Agradeço pela ajuda efetiva nas pesagens dos animais, por nunca reclamarem os feriados perdidos, por saírem de casa para que eu pudesse escrever e por me obrigarem a parar quando retornavam.

Amo vocês. 


\section{Homenagem aos Orientadores:}

Faço uma especial homenagem aos Profs. Drs. Paulo Hilário Nascimento Saldiva e João Vicente de Assunção.

Através dos ensinamentos recebidos pude idealizar este projeto, compreender os mecanismos que envolviam o processo de carcinogênese e a bioquímica ambiental, realizar este experimento, analisar resultados e discuti-los.

Através do exemplo humano pude amadurecer e evoluir tornando-me alguém melhor.

Agradeço sinceramente toda boa vontade e tempo gastos com meu doutorado, agradeço pelo estímulo nos momentos difíceis, agradeço enfim pela oportunidade de convivência e por tudo que aprendi. 


\section{Agradecimentos:}

À Citogeneticista Dra Dértia Villalba Freira-Maia, à Química Dra Célia Regina Pesqueiro, ao Engenheiro Paulo Afonso de André e à Estatística Dra Maria do Rosário de Latorre por toda ajuda recebida na concepção deste projeto.

À Biomédica Sandra Regina Castro Soares pelo estímulo constante, pela alegre forma de cumprimentar as pessoas, pela presença nos momentos necessários (da injeção do carcinógeno ao sacrificio dos animais), pelo auxílio com as referências e conselhos na redação do texto final.

À Bióloga Ana Júlia Faria Coimbra Lichtenfels, pelo total interesse e auxílio prático em meu trabalho, por haver me ensinado a dissecar camundongos.

Ao Biólogo José Rocco Júnior pela ajuda nas injeções de uretana, nas pesagens e cuidados com os animais.

À Bióloga Heloísa Maria Bueno Guimarães por todo interesse demonstrado em ajudar, pela colaboração com a redação da tese, pelas sugestões nas referências bibliográficas. Aos funcionários do Biotério do Lim 05 da Faculdade de Medicina da USP em especial à Carlos, Davi e Sérgio.

À Química Luciana do Laboratório de Investigação Médica 20 da FM/USP pela ajuda com os cálculos dos reagentes.

Ao Prof. Dr. Milton Arruda Martins e aos funcionários e pós graduandos do LIM 20 pelas utilização da bomba no momento de insuflar os pulmões.

À Bióloga Dolores Helena Ferreira Rodrigues Rivero pela gentileza e por emprestar os óculos de proteção. 
À Bióloga Débora Jã pela animada presença, pelos inteligentes comentários.

À Bióloga Eliane Tigre Guimarães pelas fotos das câmaras.

À Ana Luísa Barreiros e Reginaldo Silva do Nascimento, do Museu de Patologia, pelas fotos das lâminas e órgãos. Por estarem sempre dispostas a colaborar. Pela enorme boa vontade para comigo.

Pelo inestimável apoio no dificil momento de sacrificar os animais agradeço sinceramente à Rosa Kristan Pozo, Gabriel Braga e Braga, à Emília, ao Davi, e à Angélica.

À Regiane Carvalho de Oliveira e ao Engenheiro Químico Gustavo Buzon pelas medições dos poluentes nas Câmaras.

À Bióloga Maria Izildinha Ferreira pela ajuda na cansativa contagem dos nódulos, pelo humor inteligente, pela companhia amiga.

À Dra Thaís Mauad pela colaboração com as lâminas.

À Engenheira Química Marilin Mariano dos Santos pelas inúmeras conversas sobre poluentes, fontes e situação atual do Município de São Paulo. Pela gentil correção de meu capítulo sobre poluição.

Ao Dr. Antônio Pedro Mirra pela leitura e comentários que certamente enriqueceram em muito esta tese. Pela colaboração específica no capítulo de carcinogênese.

À Jornalista Estela Alves Cangerana, pela disposição para a leitura e correção. Por ser tão fantástica irmã.

Ao Dr Luís Alberto Amador Pereira por estar sempre perto quando meus trabalhos desabam. Pela paciente forma com que me ajuda a reerguê-los. 
À Estatística Dra Lourdes Conceição Martins pela análise estatística de meus resultados em tempo recorde e com tanta boa vontade e gentileza. Por ser uma amiga tão carinhosa.

Ao Dr. Alfésio Luís Braga pelo estímulo constante. Pela orientação nos momentos dificeis. Por estar sempre disponível e ajudar à todos.

Às técnicas do Laboratório da Patologia da FMUSP, pela confecção das lâminas de forma tão rápida e eficiente.

À Eliane Falconi Monico Gazetto e à Ana Lúcia Lorenti por toda ajuda prática, e por serem pessoas tão ecléticas e agradáveis. Pela compreensão humana que demonstram para com todos. Pela forma gentil com que sempre me trataram.

À Maria Dalva Gomes Santana e à Marcia Sueli da Silva Bento pela agradável presença na entrada do laboratório e por terem ajudado de todas as formas possíveis.

À Renata de Souza Leão Martins, à Adriana Pires, à Paulinha Regina Pereira Silva e Fernando Luís Annes pelas inúmeras conversas, pelas sugestões práticas nos momentos em que precisei.

À Renilda Shimono, à Márcia Garcia e à todos os funcionários do Serviço de Aprimoramento da Faculdade de Saúde Pública da USP, por trabalharem de forma tão eficiente e harmônica, pela agradabilíssima convivência nos últimos anos.

À Angela Maria Pereira Silva e à todos os funcionários da Secretaria de Pós-Graduação da FSP/USP, por estarem sempre dispostos a ajudar.

Aos funcionários das bibliotecas das Faculdades de Medicina e Saúde Pública pela agilidade em conseguir os artigos, pela conduta profissional. 
Ao meu pai João Alves Cangerana por demonstrar que eu era tão querida na infância, pelo exemplo de realização profissional.

À minha mãe Alice Rosa Alves Cangerana pelas primeiras letras aprendidas, pelo excepcional exemplo materno.

Aos meus quatro queridos irmãos Francisco Alves Cangerana Neto, João Alves Cangerana Júnior, Estela Alves Cangerana e Luciana Alves Cangerana Santiago. Cunhados e cunhadas, sobrinhos e sobrinhas. Meu agradecimento pelo interesse e estímulo em todos os momentos.

Às amigas Angela Pilon Vivarelli e Claudia Pereira por todas as conversas e pela compreensão para comigo. $\mathrm{E}$ às outras amigas que mesmo não estando tão perto contribuíram com seu afeto.

À toda família Grecco, e em especial às titias Yolanda, Marlene e Ercília. E ao meu querido tio João Grecco, graduado em História Natural, exemplo profissional para mim.

À minha avó Edwirges Francisca das Neves Cangerana e à todo "Clã" Cangerana das "Terras Vermelhas do Morro Agudo".

Ao Cnpq e à FAPESP pelo inestimável auxílio financeiro. 


\section{Resumo:}

Cangerana-Pereira, F.A. Efeito da Poluição do Ar na Carcinogênese de

Camundongos. São Paulo; 2004. [Tese de Doutorado- Faculdade de Saúde Pública da Universidade de São Paulo]

Este estudo buscou avaliar o potencial da poluição na promoção de neoplasias utilizando camundongos como modelo experimental. Os camundongos foram colocados em câmaras de topo aberto, nas seguintes condições de exposição: Ar Limpo, com filtro para partículas e gases; Intermediário, com filtro para gases e Ar Sujo, sem filtragem. Em cada câmara os camundongos foram divididos em dois grupos, um recebeu n-nitroso-metil-uretana ( $2 \mathrm{~g}$ por quilo de peso) e o outro serviu de controle recebendo solução salina . Os camundongos foram acompanhados por 2 meses. Os pulmões foram pesados e instilados com formol tamponado, foram observados macroscopicamente quanto à presença de tumores. A contagem macroscópica de nódulos demonstrou que existem diferenças entre os grupos. Os animais que receberam solução salina não apresentaram nódulos não importando as condições de exposição, o grupo que ficou exposto na câmara limpa apresentou uma média de 2,2 nódulos, o grupo da câmara intermediária teve como média o valor de 3,3 nódulos e o grupo da câmara suja 4,6 nódulos. A análise estatística demonstrou haver diferenças entre a câmara limpa uretana e a câmara suja uretana. Este estudo demonstrou que os poluentes do ar podem promover neoplasias pulmonares.

Descritores: Carcinogênese Ambiental, Poluição do Ar, Câncer, Uretana. 


\section{Abstract:}

Cangerana-Pereira, F.A . Effect of Air Pollution on mouse carcinogenesis São Paulo;

2004. [Tese de Doutorado- Faculdade de Saúde Pública da Universidade de São Paulo]

This study aims to evaluate the potential of air pollution on neoplasms promotion using mouse as a experimental model. Mice were placed in open top chamber, on the following conditions: Clean air, with filtration of gases and particles; Intermediary, with filtration of gases only and Dirty air, without filter. In each chamber mouse were divided in two groups, one of then received urethane $(2 \mathrm{~g} / \mathrm{k}$ of weigh) and the other was control group receiving salina solution. Mice were maintained in the chambers for two months. After this period animals were death and lungs were weigh and instilled with formol, nodules were counted. Nodules count showed differences between the groups. Control animals did not present any nodule no matter the chamber they were placed. In the urethane group, the animals placed in the clean chamber presented an average of 2,2 nodules per animal, in the intermediary chamber the average was 3,3 per animal and in the dirty chamber the average was 4,6 nodules. Statistic showed that dirty chamber urethane group was different from clean chamber urethane group. This study showed that air pollutant can promote lung neoplasms.

Descriptors: Environmental Carcinogenesis, Air Pollution, Cancer, Urethane. 


\section{Lista de Tabelas:}

Tabela 1: Emissões veiculares anuais em toneladas de poluente por combustível utilizado.........13

Tabela 2: Frota de veículos no Município de São Paulo por tipo de veículo, janeiro de 2005......14

Tabela 3: Padrões nacionais de qualidade do ar para alguns poluentes, segundo a resolução CONAMA n ${ }^{\circ} 03 / 90$

Tabela 4: Número de dias em que houve ultrapassagens do padrão de qualidade do ar e do nível de atenção na Região Metropolitana de São Paulo, 1999 à 2003 .19

Tabela 5: Classificação dos cancerígenos pelo efeito iniciador ou promotor de neoplasias. .28

Tabela 6: Análise descritiva das variáveis do experimento no Grupo Câmara Limpa Salina........70

Tabela 7: Análise descritiva das variáveis do experimento no Grupo Câmara Limpa Uretana.....70

Tabela 8: Análise descritiva das variáveis do experimento no Grupo Câmara Intermediária Salina .70

Tabela 9: Análise descritiva das variáveis do experimento no Grupo Câmara Intermediária Uretana. . .71

Tabela 10: Análise descritiva das variáveis do experimento no Grupo Câmara Suja Salina.........71

Tabela 11: Análise descritiva das variáveis do experimento no Grupo Câmara Suja Uretana......71

Tabela 12: Número de nódulos por animal que recebeu uretana por grupo de exposição. (1 $1^{\circ}$ PARTE)

Tabela 12: Número de nódulos por animal que recebeu uretana por grupo de exposição. ( $2^{\circ}$ PARTE)

Tabela 13: Média do consumo de água (mls) e ração (gramas) por grupo de camundongo por semana. 


\section{Lista de Gráficos:}

Gráficol: Número de nódulos nos pulmões dos camundongos segundo a câmara de exposição..74 Gráfico 2: Peso dos animais ao longo do experimento, por semana, por grupo que recebeu salina. 77

Gráfico 3: Peso dos animais ao longo do experimento, por semana, por grupo que recebeu uretana. .78

\section{Lista de Fotografias:}

Fotografia 1: Câmaras de Topo Aberto. .64

Fotografia 2: Caixa com filtros para partículas e gases .65

Fotografia 3: Local de colocação das Câmaras. .66

Fotografia 4: Pulmão de camundongo com nódulo .75

Fotografia 5: Adenoma Atípico (Coloração Hematoxilina Eosina). .75

Fotografia 6: Esplenomegalia encontrada na câmara suja. .82 


\section{ÍNDICE:}

1.Introdução-_-_-_-_on

1.1.Poluição do Ar- 03

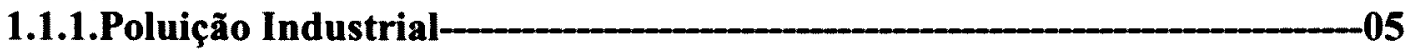

1.1.2.Poluição Veicular-_- 10

1.1.3. Monitoramento do Ar-_-16

1.1.4.Qualidade do ar no Município de São Paulo-____-_-_19

1.2.Câncer-_-_-20

1.2.1.Genes do Câncer-_____- 22

1.2.2. Carcinogênese Ambiental-__ 25

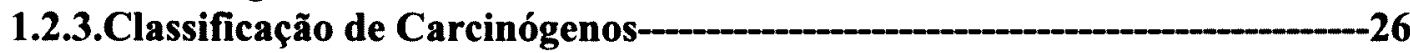

1.3.Classificação e Características dos Principais Poluentes-____-_-29

1.3.1.Ozônio-__-30

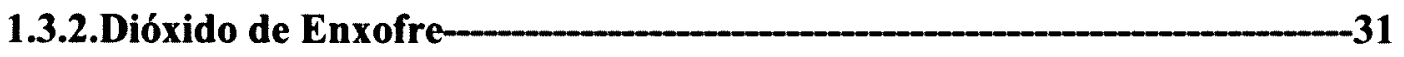

1.3.3.Monóxido de Carbono-_-__-_-_-_-32

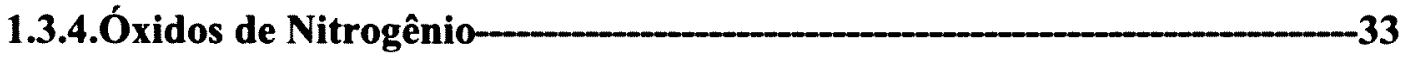

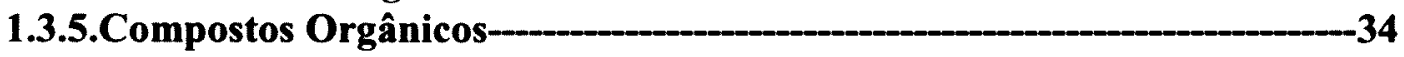

1.3.6.Material Particulado___________ 39

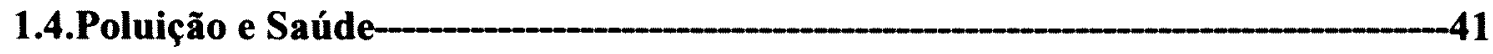

1.4.1.Poluị̧ão do Ar e Câncer-_________ 53

1.5.Objetivos-_-_- 59

2.Material e Métodos-_-

2.1.Tamanho da Amostra--_- -60

2.2.Metodologia-_-_- 61

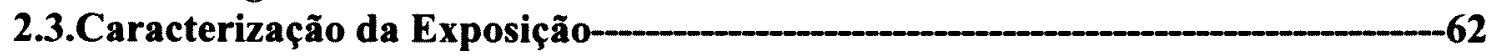

2.4.Análise Estatística-_-_- 62

2.5.Questões Éticas-___- 63

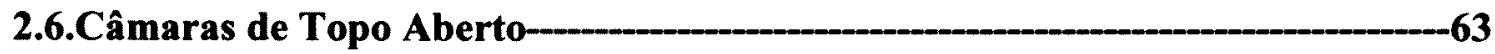

2.7.Local de Exposição-_-_-_- 66

2.8.Uretana-_-_ 67

3.Resultados-_-_- 69

3.1.Medidas de Poluição-_____ 69

3.2.Análise Descritiva das Variáveis do Experimento-_-__-_-70

3.3.Número de Nódulos-_-__- 72

3.4.Peso dos Animais-_-

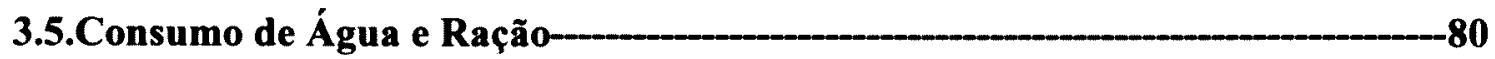

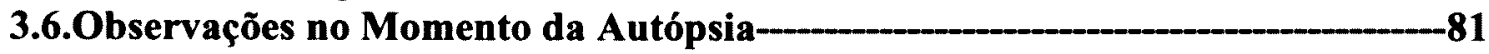

4.Discussão-_____ 83

5.Conclusões-______-

6.Referências-_._- 93 


\section{Introdução:}

O homem sempre transformou a natureza no intuito de adequá-la às suas necessidades. É possível que esta capacidade do ser humano tenha sido o diferencial que

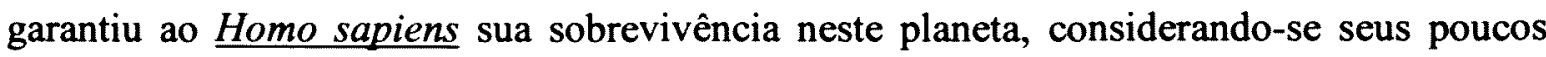
atributos físicos na competição pela vida. Com sua pele que não protege do frio nem tampouco da desidratação pelo calor excessivo, sua prole que é dependente por longo período dos progenitores, sua fragilidade em geral, somente com uma inteligência privilegiada e grande capacidade de adaptação esta espécie pode sobreviver.

Esta sobrevivência foi marcante na história do planeta, suas criações por séculos alteraram a superficie e garantiram não apenas a sobrevivência da espécie como também a qualidade desta existência. Criamos vestimentas e abrigos adequados ao frio, aprendemos a produzir e utilizar o fogo e inventamos a roda, organizamos sociedades e criamos as regras para regê-las, desenvolvemos escrita e possibilitamos a passagem do conhecimento de geração para geração. Fomos muito além e desenvolvemos sensibilidade artística, aprendendo a admirar o belo. A revolução industrial foi um marco no desenvolvimento humano e acelerou em muito o processo de alteração do meio. Esta profunda transformação da natureza teve seus efeito colaterais. A extinção acelerada de algumas espécies animais e vegetais, o desvio dos cursos de rios, a transformação de florestas em pastos, a impermeabilização do solo, a sobrecarga do meio ambiente com resíduos sólidos em quantidades alarmantes, a poluição da água, do ar, e do solo. A qualidade do ambiente em que vive determina o status de saúde e bem-estar humanos. Desta forma, se por um lado as 
alterações do ambiente garantiram a sobrevivência da espécie, por outro estas mesmas alteracões causaram danos ao meio ambiente trazendo inúmeros prejuizos. 


\subsection{Poluição do ar:}

Considera-se poluente atmosférico qualquer substância presente no ar e que, pela sua concentração, possa torná-lo impróprio, nocivo ou ofensivo à saúde, causando inconveniente ao bem estar público, danos aos materiais, à fauna e à flora ou seja prejudicial à segurança, ao uso e gozo da propriedade $\mathrm{e}$ às atividades normais da comunidade. $\mathrm{O}$ nível de poluição atmosférica é medido pela quantidade de substâncias poluentes presentes no ar. A variedade das substâncias que podem ser encontradas na atmosfera é muito grande, o que torna dificil a tarefa de estabelecer uma classificação. Para facilitar esta classificação, os poluentes atmosféricos são divididos em duas categorias:

Poluentes Primários: aqueles emitidos diretamente pelas fontes de emissão.

Poluentes Secundários: aqueles formados na atmosfera através da reação química entre as diversas substâncias presentes na atmosfera, poluentes ou não, e determinadas condições fisicas.

As substâncias poluentes podem ser classificadas, ainda, da seguinte forma:

Compostos de Enxofre $\left(\mathrm{SO}_{2}, \mathrm{SO}_{3}, \mathrm{H}_{2} \mathrm{~S}\right.$, Sulfatos,), Compostos de Nitrogênio (NO, $\mathrm{NO}_{2} \mathrm{O}, \mathrm{N}_{2} \mathrm{O}, \mathrm{NH}_{3}, \mathrm{HNO}_{3}$, Nitratos), Compostos Orgânicos voláteis (hidrocarbonetos, álcoois, aldeídos, cetonas, ácidos orgânicos), Compostos Halogenados (HCI, HF, cloretos, fluoretos), Monóxido de Carbono, Material Particulado, e Oxidantes Fotoquímicos (Ozônio).

A interação entre as fontes de poluição e a atmosfera vai definir o nível de qualidade do ar. A qualidade do ar por sua vez, determina o surgimento de efeitos adversos da poluição sobre os receptores (o homem, os animais, as plantas e os materiais). $O$ monitoramento sistemático da qualidade do ar, é restrito a um número de poluentes, 
definidos em função de sua importância e dos recursos disponíveis para seu monitoramento. $\mathrm{O}$ grupo de poluentes que servem como indicadores de qualidade do ar, adotados universalmente e que foram escolhidos em razão da freqüência de ocorrência e de seus efeitos adversos, são:

Material Particulado (MP), Dióxido de Enxofre (SO2), Monóxido de Carbono (CO), Oxidantes Fotoquímicos- como o Ozônio (O3), Hidrocarbonetos, Óxidos de Nitrogênio.

Em zonas urbanas, como o Município de São Paulo, a poluição do ar é derivada de duas fontes: as fontes industriais ou fixas e as fontes veiculares ou móveis. No Município de São Paulo existem atualmente cerca de 2000 indústrias com alto potencial poluidor e uma frota de aproximadamente 6 milhões de veículos, o que corresponde a 1/5 do número de veículos total do País (DETRAN, 2005). Essas fontes liberam, entre outras substâncias não monitoradas, 1,8 milhão de tonelada por ano de Monóxido de Carbono, 415 mil toneladas por ano de Hidrocarbonetos, 409 mil toneladas por ano de Óxidos de Nitrogênio, 67 mil toneladas por ano de Material Particulado, e 37 mil toneladas por ano de Óxidos de Enxofre. (ABGNV, 2004)

Através das medições de poluentes podemos afirmar que, atualmente as fontes que causam maiores danos ao ar atmosférico deste Município são as veiculares. Uma melhor análise das fontes emissoras de poluentes está apresentada à seguir: 


\subsubsection{Poluição Industrial:}

As emissões atmosféricas provenientes dos processos industriais são grandemente variáveis e freqüentemente misturas complexas. Indústrias, como as de base que geram produtos a partir de materiais em estado bruto, são as que provocam maior impacto ambiental, principalmente devido ao seu porte. Indústrias como: refinarias de petróleo, siderurgias, termoelétricas e fábricas de cimento lançam para a atmosfera grandes quantidades de gases e material particulado os quais podem causar sérios danos à saúde pública e ao meio ambiente. As indústrias siderúrgicas contribuem de forma significativa para a poluição atmosférica e os poluentes por elas gerados ainda não estão completamente estudados.

Na década de 1970 houve um grande aquecimento da economia no país graças ao milagre econômico. Em São Paulo, classicamente um pólo industrial brasileiro, o número de indústrias cresceu significativamente e a produção aumentou em grande escala. Esta produção desenfreada aumentou a concentração dos poluentes na atmosfera atingindo níveis alarmantes, principalmente no Município de Cubatão, na Baixada Santista. Em 1972 a Cetesb (Companhia de Tecnologia de Saneamento Ambiental) iniciou a avaliação da qualidade do ar, através de uma rede de monitoramento manual, composta de 14 estações, medindo os teores de dióxido de enxofre e fumaça. Objetivando controlar das emissões de poluentes industriais foram desenvolvidas ações exigindo a instalação de equipamentos que reduzissem a emissão dos poluentes emitidos pelas indústrias já instaladas. Ao mesmo tempo foram criadas licenças ambientais para instalação e para funcionamento de novos empreendimentos que caracterizassem uma fonte potencialmente poluidora. O programa de controle sobre as fontes estacionárias abrange o controle de material particulado e o 
controle do dióxido de enxofre. O controle do material particulado, iniciado em dezembro de 1979 , é baseado na aplicação de tecnologias visando a redução da emissão deste poluente. As maiores fontes emissoras, que eram responsáveis por $90 \%$ do particulado industrial, receberam prazo de cinco anos para se adequarem aos requisitos necessários. $\mathrm{O}$ consumo de óleos combustíveis com altos teores de enxofre originaram o problema de poluição do ar por $\mathrm{SO}_{2} . \mathrm{O}$ programa de controle de $\mathrm{SO}_{2}$ iniciado em 1982 concentrou-se nos processos de combustão, e tinha como meta não somente a redução das emissões de $\mathrm{SO}_{2}$ por meio de exigências junto ao gerador (indústrias) mas também a redução do teor de enxofre nos combustiveis utilizados. O padrão de emissão foi estabelecido em $20 \mathrm{~kg}$ de $\mathrm{SO}_{2}$ por tonelada de óleo queimado para novas fontes e $40 \mathrm{~kg}$ para fontes já existentes. As indústrias receberam prazo de cinco anos para a adequação (Cetesb, 1994).

As medidas legais tomadas na década de 1980 para controle da poluição do ar pelas indústrias levou à uma diminuição significativa dos poluentes gerados por este tipo de fonte. Atualmente no Município de São Paulo a fonte fixa não é mais o principal problema, os níveis de poluição provenientes das indústrias foram reduzidos e hoje essas fontes são responsáveis pela emissão de apenas $10 \%$ dos poluentes presentes na atmosfera (Cetesb, 2004).

Nos últimos anos muitas indústrias receberam a certificação ISO 14000 que garante o cumprimento da legislação vigente. Esta certificação proporciona melhor controle ambiental, beneficios financeiros resultantes da redução de gastos com energia e redução dos desperdícios, aumento das oportunidades no mercado. Procurando atender a preocupação mundial quanto ao meio ambiente, a ISO 14000 normatizou o Gerenciamento Ambiental de forma eficaz e eficiente, estabelecendo e mantendo procedimentos que 
auxiliam na identificação, exame e avaliação de efeitos ambientais quanto a poluição. A certificação segundo a ISO 14.00 é voluntária. Esta certificação auxilia as empresas a demonstrar o seu comprometimento com o desenvolvimento sustentável. Para tanto, é preciso ter uma Política Ambiental que vise minimizar os rejeitos gerados no processo produtivo, reaproveitando através de desenvolvimento de novos produtos, reciclando ou tratando-os e transformando-os em material inerte. (Iso14000 Foundation, on line 20,21/Abril/2004)

Além da certificação ISO1400 e selos ambientais, muitas indústrias tem protocolos próprios de controle da emissão e resíduos. Grandes empresas trabalham em conformidade com o "Responsable Care", um acordo que visa estabelecer comportamentos produtivos voltados para a preservação do meio ambiente. Em São Paulo pequenas e grandes empresas trabalham com a filosofia de produção mais limpas cujo objetivo é minimizar os desperdícios, o uso de recursos naturais e de substâncias tóxicas. O principal impacto do uso de produção mais limpa, pode-se dizer que seja a minimização de danos ambientais. Com essas medidas é esperado que a emissão de efluentes e matérias primas poluidoras sejam diminuídos.

O controle das emissões industriais é feito medindo-se as concentrações dos poluentes diretamente na chaminé. $O$ conhecimento das substâncias que estão saindo do processo produtivo possibilita saber se está havendo perda de matéria-prima, energia ou água. Desta forma é também de interesse financeiro por parte da indústria o controle de seus rejeitos. 
No estado de São Paulo, a CETESB (on line, 24/novembro/2003) definiu novas políticas e estratégias criando uma Divisão para tratar de assuntos relativos a Produção mais Limpa (P+L), Prevenção à Poluição (P2) e Sistemas de Gestão Ambiental (SGA).

A Conferência das Américas para Produção mais Limpa, ocorrida em 1998 foi organizada pela CETESB em conjunto com a USEPA (United States Environmental Protection Agency), UNEP (United Nations Environment Programme), o Banco Mundial, a Agência Ambiental do Canadá, dentre outros. Esta Conferência foi a principal etapa na consolidação da Produção mais Limpa e da Prevenção à Poluição no continente americano, nela ocorreu o lançamento da mesa redonda das Américas para Produção mais Limpa.

Outros programas de prevenção são adotados, principalmente, durante os meses de inverno. Neste periodo os níveis de poluição atmosférica tendem a aumentar devido às péssimas condições para a dispersão dos poluentes. No Município de São Paulo, por exemplo, é desenvolvido um programa junto às indústrias para que estas adotem uma série de medidas visando a diminuição dos poluentes gerados como o uso de óleo combustível com baixo teor de enxofre e a interrupção ou substituição de alguns processos produtivos a partir de determinados níveis de concentração de poluentes, conforme determina a legislação.

A estratégia de redução ou eliminação de resíduos ou poluentes na fonte geradora consiste no desenvolvimento de ações que promovam a redução de desperdícios, a conservação de recursos naturais, a redução ou eliminação de substâncias tóxicas presentes em matérias-primas ou produtos auxiliares, a redução da quantidade de resíduos gerados por processos e produtos, e consequentemente, a redução de poluentes lançados para o ar, solo e águas. Diversos termos, tais como: Produção mais Limpa (Cleaner Production), 
Prevenção à Poluição (Pollution Prevention), Tecnologias Limpas (Clean Technologies), Redução na Fonte (Source Reduction) e Minimização de resíduos (Waste Minimization) têm sido utilizados, mundialmente, para definir este conceito.

Os termos Prevenção à Poluição $(\mathrm{P} 2)$ e Produção mais Limpa $(\mathrm{P}+\mathrm{L})$ são utilizados pela CETESB. O primeiro já é consagrado nos EUA (Estados Unidos da América) e foi disseminado pela EPA (Environmental Protection Agency), através de um Decreto Lei promulgado pelo Governo Federal Americano, em 1990. O segundo foi definido pelo UNEP (United Nations Environmental Programme) durante o lançamento do Programa de Produção mais Limpa, em 1989.

Como descrito acima muito tem sido feito por parte das indústrias e dos Organismos Governamentais no sentido de garantir que a poluição industrial fique dentro dos limites exigidos pela legislação, causando o menor impacto ambiental possível. 


\subsubsection{Poluição Veicular:}

Enquanto medidas de prevenção e controle da fonte industrial estavam sendo tomadas em São Paulo, a frota de veículos crescia neste Município. Na medida em que a poluição industrial foi sendo controlada a emissão veicular foi aumentando mantendo a região poluída por esta nova fonte. O Brasil apresenta um crescimento explosivo de suas regiões metropolitanas. O Estado de São Paulo enfrenta uma situação particularmente preocupante por deter aproximadamente $40 \%$ da frota automotiva do país. A frota motorizada no Estado de São Paulo, em dezembro de 2001, era de aproximadamente 13,2 milhões de veículos. Destes, quase 6 milhões de veículos pertencem a frota da Região Metropolitana de São Paulo (RMSP). (DETRAN, 2005)

Para controlar a poluição emitida por fontes móveis foi estabelecido o Programa de Controle da Poluição do Ar por Veículos Automotores (PROCONVE) através da Resolução $n^{\circ}$ 18/86 do CONAMA (Conselho Nacional do Meio Ambiente), definindo os limites máximos de emissão para todos os veículos novos, leves e pesados, nacionais e importados. Assim, todos os novos modelos de veículos e motores. nacionais e importados são submetidos obrigatoriamente à homologação quanto à emissão de poluentes. São analisados os parâmetros relevantes à emissão de poluentes, sendo também submetidos a ensaios de laboratório, onde as emissões de escapamento são comparadas aos limites máximos de emissão em vigor. Desde que foi implantado, o Programa reduziu a emissão de poluentes de veículos novos em cerca de $97 \%$, por meio da limitação progressiva da emissão de poluentes, da introdução de tecnologias (como catalisador, injeção eletrônica de combustivel e melhorias na qualidade dos combustíveis automotivos). Os limites de emissão para veículos leves e pesados foram definidos pela Lei Federal n 8723 de 1993. 
Os fabricantes de veículos vêm cumprindo as exigências legais, o que resultou na redução média da ordem de $93 \%$ na emissão de poluentes dos veículos leves novos de 2001 . Os veículos leves são o maior problema a ser enfrentado devido a sua grande quantidade e intensa utilização. As ações do PROCONVE sobre a frota de veículos de quatro rodas tem propiciado ganhos ambientais pois, segundo a CETESB (on line), embora a frota de automóveis, ônibus e caminhões tenha crescido de forma surpreendente nos últimos anos, a qualidade do ar não tem sido prejudicada e os períodos de inverno mais recentes passaram sem a ocorrência de episódios críticos de poluição do ar causados por fontes veiculares.

A frota de motocicletas vem crescendo nos últimos anos e seu perfil de utilização é predominante prestação de serviços de entregas em regiões urbanas. Vale citar que as motocicletas, na Região Metropolitana de São Paulo, emitem anualmente 238,9 mil toneladas de monóxido de carbono ( Associação Brasileira de Gás Natural Veicular, 2004).

Tendo em vista o crescimento deste setor tornou-se necessário o estabelecimento de um programa específico para o controle das emissões desses veículos. Foram criados parâmetros para o controle da poluição pelos veículos de duas rodas, o Programa de Controle da Poluição do Ar por Motociclos e Veículos Similares (PROMOT). Este programa foi baseado nas legislações vigentes na Europa sendo os primeiros limites de emissão propostos para vigorar a partir de 01 de janeiro de 2003 , considerando que o atual estágio tecnológico da indústria nacional possibilita o atendimento desta meta de controle (CETESB, on line).

Dos 13,2 milhões de veículos do estado de São Paulo, a frota de veículos movida à Diesel (caminhões, ônibus, microônibus, caminhonetes e vans) é de 988,5 mil veículos. 419,4 mil veículos que utilizam óleo diesel como combustível pertencem a RMSP. Estes 
veículos pesados formam uma importante fonte de poluição. Quando estão desregulados emitem fumaça preta, que são minúsculas partículas de carbono embebidas por substâncias oleosas. Durante os meses de inverno (maio à setembro), devido à dificuldade de dispersão de poluentes na atmosfera, a fiscalização é intensificada numa operação denominada CaçaFumaça. No ano de 2001, a média anual de fumaça no município de São Paulo foi $40 \mu \mathrm{g} / \mathrm{m} 3$, a mais baixa observada nos 28 anos de amostragem. Tal fato é justificado pela intensificação da Operação Caça-Fumaça, o que levou uma redução total de $84 \%$ dos veículos a diesel desregulados nos últimos 7 anos (Cetesb, 2004).

Somado às ações de controle citadas acima, os combustíveis utilizados têm um papel muito importante no controle da poluição ambiental. A partir de 1979, com o início do Programa Nacional do Álcool (PRÓALCOOL), ocorreram modificações na composição dos combustiveis utilizados pelos veículos automotores. Foi iniciado o fornecimento da mistura da gasolina com o álcool anidro e a produção de veículos movidos a etanol. A porcentagem de $22 \%$ de etanol em volume de gasolina foi adotada pelo CONAMA em 1990, por recomendação do setor energético. A Medida Provisória n 1662-3/98 elevou o teor de álcool etílico anidro na gasolina para $24 \%$ em volume, tal alteração não teve impacto significativo sobre as emissões dos veículos graças às novas tecnologias adotadas pelos fabricantes (CETESB, on line).

Recentemente surgiu uma nova opção de combustivel para veículos, o gás natural veicular (GNV), que, teoricamente, reduz as emissões a dióxido de carbono e vapor d'água. Desta forma, os veículos movido a GVN não emitem óxidos de enxofre devido ao fato de que o GNV não possui enxofre em sua composição, chumbo por não haver necessidade de utilizar aditivos a base de chumbo, tetraetila e particulados devido a combustão completa 
do GNV ser mais facilmente atingida quando comparada com gasolina e diesel. Quanto ao monóxido de carbono, os veículos a GNV podem gera-lo também, porém em menor quantidade quando comparado com os demais combustíveis veiculares. Assim, o uso do GNV tem papel importante na redução dos níveis de concentração de poluentes atmosféricos emitidos pelas fontes móveis e consequentemente nos índices de qualidade do ar, principalmente nos grandes centros urbanos onde o número de veículos circulando diariamente é muito grande. Acrescente-se a isto o fato de que por ser um combustível gasoso, possui um sistema de armazenamento e abastecimento do motor isolado da atmosfera, reduzindo bastante as emissões fugitivas (perdas) por manipulação para abastecimento e estocagem e as devidas a evaporação dos combustíveis líquidos que ocorrem respiros dos tanques de. No ambiente urbano, o uso adequado do GNV, se comparado com os combustíveis tradicionais, podem reduzir as emissões de monóxido de carbono (CO) em $76 \%$, de óxidos de nitrogênio (NOx) em $84 \%$, e de hidrocarbonetos pesados $(\mathrm{CnHm})$ em $88 \%$, praticamente eliminando as emissões de benzeno e formaldeídos (ABGNV, 2004).

A tabela 1 apresenta as emissões anuais veiculares em toneladas de poluentes por combustivel utilizado.

Tabela 1: Emissões veiculares anuais em toneladas de poluente por combustível utilizado,2004. COMBUSTÍVEL/

\begin{tabular}{ccccccc} 
POLUENTE & CO & NOX & $\begin{array}{c}\text { HIDROCARBO } \\
\text { NETOS }\end{array}$ & SOX & $\begin{array}{c}\text { MATERIAL } \\
\text { PARTICU } \\
\text { LADO }\end{array}$ \\
\hline Gasolina & 790.200 & 51.800 & 84.200 & - & \\
Álcool & 211.500 & 12.600 & 22.900 & & \\
Diesel & 444.400 & 324.500 & 72.400 & 11.200 & 20.200 \\
\hline
\end{tabular}


Todos os combustíveis líquidos através de seu manuseio e mesmo acondicionados em tanques, produzem ainda cerca de 168 mil toneladas anuais de emissões fugitivas de hidrocarbonetos devido a processos evaporativos. (ABGNV,2004)

A tabela 2 mostra a distribuição da frota do Município de São Paulo por tipo de veículo.

Tabela 2: Frota de veículos no Município de São Paulo por tipo de veículo, janeiro de 2005.

\begin{tabular}{cc} 
Tipo de Veículo & Número \\
\hline Ciclomotores, Motonetas, Motociclos, Tríciclos e Quadricíclos. & 503.937 \\
Microonibus, Caminhoneta, Caminhonete, Utilitários & 502.071 \\
Automóveis & 4.494 .626 \\
Ônibus & 44.672 \\
Caminhões e Carga & 172.513 \\
Reboques e Semi-reboques & 76.919 \\
Outros & 6.456 \\
Total & 5.801 .194 \\
\hline
\end{tabular}

Embora tenham sido implantadas várias medidas (políticas públicas) no sentido de garantir que os padrões de qualidade do ar sejam obedecidos, a fonte móvel ainda é responsável pela maior parte dos poluentes lançados para a atmosfera. A frota veicular está sendo renovada muito lentamente. Contudo, os veículos novos, que saem de fábrica com equipamentos que minimizam a emissão de poluentes, precisam de adequada manutenção para assegurar a eficácia destes dispositivos visto que a substituição dos veículos antigos por veículos novos por si só não garante a redução dos níveis de emissão dos veículos novos. É necessário garantir também que os veículos sejam mantidos conforme as recomendações do fabricante.

Objetivando a manutenção e controle da emissão de poluentes pelos veículos foi criado o Programa de Inspeção Veicular (PIV) no Estado de São Paulo, espera-se que o 
Programa de PIV, quando implantado, reduza as emissões totais médias da frota circulante em até $30 \%$, dependendo do poluente em questão e das características técnicas de implementação a serem adotadas (Cetesb, on line). 


\subsubsection{Monitoramento do Ar:}

As concentrações máximas de um poluente atmosférico para garantir a saúde e o bem estar das pessoas são definidas legalmente em um padrão de qualidade do ar. Estudos científicos dos efeitos dos poluentes estabelecem os níveis máximo aceitáveis.

No Brasil, os padrões nacionais de qualidade do ar foram estabelecidos pelo IBAMA através da Portaria Normativa $n^{\circ} 348 / 90$ e Resolução CONAMA $n^{\circ}$ 03/90. São estabelecidos dois tipos de padrões - primários e secundários.

Os padrões primários são as concentrações de poluentes que, se ultrapassadas, poderão afetar a saúde da população. Por padrão secundário compreende-se a concentração máxima abaixo da qual ocorra o mínimo efeito adverso sobre o bem estar da população, bem como o mínimo dano à flora ou à fauna.

A resolução do CONAMA prevê ainda que o país seja dividido em áreas para que a aplicação dos padrões seja diferenciada. Os padrões nacionais de qualidade do ar são apresentados na tabela abaixo.

Tabela 3: Padrões nacionais de qualidade do ar para alguns poluentes, segundo a resolução CONAMA n⿳0 03/90.

\begin{tabular}{|c|c|c|c|}
\hline POLUENTE & $\begin{array}{l}\text { PERÍODO DE } \\
\text { EXPOSIÇÃO }\end{array}$ & $\begin{array}{c}\text { PADRÃO } \\
\text { PRIMÁRIO } \\
(\boldsymbol{\mu g} / \mathbf{m} 3) \\
\end{array}$ & $\begin{array}{c}\text { PADRÃO } \\
\text { SECUNDÁRIO } \\
(\mu \mathrm{g} / \mathrm{m} 3) \\
\end{array}$ \\
\hline $\begin{array}{l}\text { PARTÍCULAS TOTAIS EM } \\
\text { SUSPENSÃO }\end{array}$ & 24 horas/Anual & $240 / 80$ & $150 / 60$ \\
\hline $\begin{array}{l}\text { PARTÍCULAS INALÁVEIS } \\
\text { FUMAÇA }\end{array}$ & $\begin{array}{l}24 \text { horas/Anual } \\
24 \text { horas/Anual }\end{array}$ & $\begin{array}{l}150 / 50 \\
150 / 60\end{array}$ & $\begin{array}{l}150 / 50 \\
100 / 40\end{array}$ \\
\hline $\begin{array}{l}\text { DIÓXIDO DE ENXOFRE } \\
\text { (SO2) }\end{array}$ & 24 horas/Anual & $365 / 80$ & $100 / 40$ \\
\hline $\begin{array}{c}\text { MONÓXIDO DE CARBONO } \\
\text { (CO) } \\
\text { OZÔNIO (O3) }\end{array}$ & $\begin{array}{c}1 \text { hora } / 8 \text { horas } \\
1 \text { hora }\end{array}$ & $\begin{array}{c}40.000(35 \mathrm{ppm}) / \\
10.000(9 \mathrm{ppm}) \\
160\end{array}$ & $\begin{array}{c}40.000(35 \mathrm{ppm}) / \\
10.000(9 \mathrm{ppm}) \\
160\end{array}$ \\
\hline $\begin{array}{l}\text { DIÓXIDO DE NITROGÊNIO } \\
\text { (NO2) }\end{array}$ & 1 hora/Anual & $320 / 100$ & $190 / 100$ \\
\hline
\end{tabular}


O controle da qualidade do ar é feito por meio de redes de monitoramento que podem ser do tipo manual ou automática.

No estado de São Paulo a rede automática entrou em operação em 1981 com estações medidoras distribuídas pela Região Metropolitana de São Paulo - RMSP e Cubatão. Essa rede foi renovada em 1996. Em 2000 o monitoramento automático foi ampliado para as cidades de Campinas, São José dos Campos, Sorocaba e Paulínia, totalizando 29 estações. Parte das estações do Estado de São Paulo estão ligadas a uma central via telemetria, que recebe os dados de concentrações de cada poluente monitorados. Cada poluente tem um analisador, que aspira o ar atmosférico. As informações são enviadas de hora em hora por telemetria. A cada 24 horas é emitido um Boletim de Qualidade do ar informando os valores médios dos poluentes medidos e os índices de qualidade do ar das últimas 24 horas.

A legislação ambiental estadual, regulamentada pelo Decreto $8468 / 76$, instituiu o Plano de Emergência para Episódios Críticos de Poluição do Ar, visando coordenar as medidas necessárias a serem adotadas pelo Estado, Municípios, entidades privadas e comunidade para evitar riscos à saúde da população. O conjunto de medidas é estabelecido conforme a Qualidade do ar (Atenção, Alerta e Emergência), a qual é definido em função do índice de qualidade do ar que por sua vez é estabelecido em função do poluente que apresentar o pior índice de qualidade do ar. Considera-se episódio crítico de poluição do ar a presença de altas concentrações de poluentes na atmosfera em curto período de tempo, resultante da ocorrência de condições meteorológicas desfavoráveis à sua dispersão. Cabe ao Secretário de Estado do Meio Ambiente declarar os níveis de Atenção e de Alerta e ao 
Governador o de Emergência. Durante os episódios críticos, as fontes de poluição do ar estão sujeitas às seguintes restrições:

Estado de Atenção: Quando o Estado de Atenção é declarado, devido a monóxido de carbono ou oxidantes fotoquímicos, é solicitada a restrição voluntária do uso de veículos automotores particulares. No caso do material particulado ou dióxido de enxofre, as atividades industriais como limpeza de caldeiras ou a operação de incineradores só podem ser realizadas em um período determinado do dia, assim como devem ser adiados o início de novas operações de processamentos industriais. Devem ser eliminadas imediatamente as emissões de fumaça preta por fontes estacionárias que estiverem fora dos padrões legais, bem como a queima de qualquer material ao ar livre.

Estado de Alerta: No caso do Estado de Alerta ser declarado por monóxido de carbono ou oxidantes fotoquímicos, fica impedida a circulação de veículos na área atingida, no período das 6 às 21 horas. Se os poluentes responsáveis pelo estado de Alerta forem o material particulado ou o dióxido de enxofre ficam proibidas as operações industriais de limpeza de caldeira, operação de incineradores e circulação de veículos a óleo diesel fora dos padrões legais.

Estado de Emergência: Declarado o Estado de Emergência, no caso de $\mathrm{CO}, \mathrm{O} 3$ e SO2, são totalmente proibidas a circulação e o estacionamento de veículos na área atingida, assim como são totalmente paralisadas as operações industriais, quando os poluentes forem o MP ou o SO2. (Cetesb, on line) 


\subsubsection{Qualidade do ar no Município de São Paulo:}

Como visto nos capítulos anteriores, no que concerne a poluição do ar a Região Metropolitana de São Paulo é uma área prioritária uma vez que, como todo grande centro urbano, apresenta forte degradação da qualidade do ar.

Na tabela abaixo podemos observar o número de dias em que ocorreu ultrapassagens do padrão de qualidade do ar e do nível de atenção nos anos de 1999 à 2003 .

Tabela 4: Número de dias em que houve ultrapassagens do padrão de qualidade do ar e do nível de atenção na Região Metropolitana de São Paulo, 1999 à 2003.

\begin{tabular}{|c|c|c|c|c|c|c|c|c|c|c|}
\hline \multirow[t]{2}{*}{ POLUENTE } & \multicolumn{2}{|c|}{1999} & \multicolumn{2}{|c|}{2000} & \multicolumn{2}{|c|}{2001} & \multicolumn{2}{|c|}{2002} & \multicolumn{2}{|c|}{2003} \\
\hline & PQAR & At. & PQAR & At & PQAR & At & PQAR & At & PQAR & At \\
\hline $\begin{array}{l}\text { PARTÍCULAS } \\
\text { INALÁVEIS }\end{array}$ & 61 & 1 & 38 & 0 & 42 & 0 & 23 & 0 & 28 & 0 \\
\hline $\begin{array}{l}\text { DIÓXIDO DE } \\
\text { ENXOFRE (SO2) }\end{array}$ & 0 & 0 & 0 & 0 & 0 & 0 & 0 & 0 & 0 & 0 \\
\hline $\begin{array}{l}\text { MONÓXIDO DE } \\
\text { CARBONO (CO) }\end{array}$ & 18 & 0 & 12 & 0 & 13 & 0 & 16 & 0 & 22 & 0 \\
\hline $\begin{array}{l}\text { OZÔNIO (O3) } \\
\text { DIÓXIDO DE }\end{array}$ & 294 & 98 & 253 & 79 & 285 & 95 & 335 & 133 & 284 & 84 \\
\hline $\begin{array}{c}\text { NITROGÊNIO } \\
\text { (NO2) }\end{array}$ & 11 & 0 & 2 & 0 & 6 & 0 & 2 & 0 & 3 & 0 \\
\hline
\end{tabular}

Como é possivel observar na tabela, existe uma tendência de queda dos níveis dos poluentes na Região Metropolitana de São Paulo. O padrão de qualidade do ar tem sido observado para quase todos os parâmetros com exceção do poluente ozônio, que apresenta uma tendência ascendente. 


\subsection{Câncer:}

O Câncer é um dos problemas mais comuns e intensos da saúde pública. Não é uma doença única, mas sim um nome empregado para uma grande variedades de tumores malignos que se formam pelo mesmo processo básico de crescimento descontrolado. Para entender este processo, precisamos entender o processo de desenvolvimento celular que se inicia no momento da fecundação do óvulo pelo espermatozóide, dando origem ao ovo. Esta célula contém, em seu núcleo, toda a informação genética necessária para o desenvolvimento e funcionamento do novo ser. A informação genética está armazenada no DNA genômico, sob forma de cromossomas, e é determinada pela combinação de quatro bases nitrogenadas que constituem o DNA e são conhecidas pelas letras $A, T, C$ e G (adenina, timina, citosina e guanina). Essas bases ordenadas ao longo do DNA vão determinar a seqüência dos genes. A seqüência dessas bases nos milhares de genes serão transcritas; A, C, G e U ( adenina, citosina, guanina e uracila). As seqüências dessas bases no RNA serão decodificadas, dando origem às proteinas que são responsáveis pelas atividades metabólicas e estruturais das células. Para a sintese das proteínas, cada combinação de 3 bases nitrogenadas no RNA representam um aminoácido específico. Assim, pelo fluxo da informação genética, a seqüência de bases no DNA é quem determina a seqüência de aminoácidos na proteína. A célula-ovo, por divisões sucessivas, vai dar origem a todas as células que compõem o indivíduo, passando por complexos processos de diferenciação, para formar os diferentes órgãos, e exercer as mais variadas funções metabólicas do organismo. O aparecimento de células diferentes, capazes de executarem diferentes atividades metabólicas é um reflexo direto da ativação/expressão de diferentes genes. Desta forma podemos entender que, apesar de no indivíduo, diferentes células 
exercerem atividade metabólica diferentes, elas ainda permanecem idênticas no que se refere ao conteúdo genético do seu DNA. Sendo diferentes apenas nas porções ativas do seu genoma. No decorrer da vida, o DNA sofre alterações denominadas de mutações, causadas por erros que ocorrem durante a duplicação do DNA, necessária para a divisão celular. O aparecimento de mutações no DNA ocorre em todos os seres vivos, um processo que é fundamental para a evolução e diversidade das espécies. Muitas destas mutações não implicam em mudanças detectáveis na atividade metabólica, e passam desapercebidas. Outras mutações podem determinar a apoptose celular, e por conseqüência, também não são detectáveis. Apenas um pequeno número de mutações que ocorrem em genes especificos podem determinar vantagens e um crescimento desordenado das células. Os chamados agentes mutagênicos que vão alterar a seqüência das bases no DNA, aceleram o aparecimento de mutações e, por uma questão de estatística, podem aumentar a freqüência do aparecimento de mutações que estão associadas ao desenvolvimento dos tumores. Com o passar das divisões, uma célula poderá acumular mutações que, se em número elevado, poderá determinar a perda do controle de sua divisão, determinando assim o aparecimento do câncer ou tumor (Fundação Antônio Prudente on line). Este tumor é, então, uma massa que invade os tecidos vizinhos e também pode enviar metástases para locais mais distantes. O crescimento é autônomo e, se não tratado, invariavelmente é fatal (Thompson et al, 1993).

Um tumor é composto de um parênquima de células em proliferação, com um estroma de tecido conjuntivo e vasos sanguíneos. Podem ser divididos em três tipos: Sarcomas- a origem é o tecido mesenquimal; Carcinomas- originou-se do tecido epitelial; Neoplasias Hematopoiéticas e Linfóides (Thompson et al, 1993). 


\subsubsection{Genes do Câncer:}

Existem dois tipos de genes relacionadas às neoplasias, os oncogenes e os genes de supressão de tumor. Os primeiros facilitam a transformação enquanto os outros bloqueiam o desenvolvimento do tumor. (Miller, 1990)

Os oncogenes são genes que afetam o crescimento e desenvolvimento de células normais. Uma mutação do gene ou uma alteração do controle pode ocasionar uma expressão excessiva deste gene, a célula onde ocorreu este alteração pode sofrer um crescimento descontrolado. A maioria de oncogenes é a forma ativada de um gene normal, denominado de proto-oncogene. (Miller et al, 1990) Muitos dos oncogenes identificados em tumores humanos relacionam-se com oncogenes isolados de vírus tumorais de RNA. Foi através da demonstração de que a informação genética de um vírus pode transformar uma célula normal em tumor que ficou estabelecido que o gene teria um papel central nesta transformação (Thompson, 1993).

Os oncogenes possuem um efeito dominante a nível celular, isto ficou demonstrado a partir da observação de um oncogene ras de uma linhagem celular de carcinoma de bexiga. O oncogene e seu proto-oncogene diferiam em um par de bases, a alteração em uma célula somática levou à formação do tumor, ou seja, um único alelo mutante foi capaz de levar ao fenótipo tumoral. Através da observação de mutações puntiformes do gene ras em muitos tumores mostrou-se que o ras é o alvo de diferentes carcinógenos (Marx, 1987; Weinberg, 1990).

A mutação estrutural é apenas um dos mecanismos que induzem a ativação de um proto-oncogene. Translocações cromossômicas são um outro meio. A translocação do proto-oncogene $a b l$ de sua posição no cromossoma 9 ao ponto de quebra no cromossoma 
22 em uma célula hematopoiética primordial leva à Leucemia Mielóide Crônica (LMC). As alterações citogenéticas são mais freqüentes nos estágios mais avançados do tumor (Mitelman, 1988).

A amplificação do gene é outro modo de ativar o proto-oncogene. Dois tipos de alterações citogenéticas são indicativas da amplificação gênica; minúsculos duplos, que são pequenos cromossomas acessórios e regiões de coloração homogênea que contém inúmeras cópias de um segmento de DNA. As cópias extras dos proto-oncogenes provocam efeitos sobre a multiplicação celular. Um único oncogene não é suficiente para desencadear o processo de carcinogênese, mais de um proto-oncogene precisa ser ativado, a carcinogênese é um processo de múltiplas etapas (Thompson, 1993).

O outro tipo de gene relacionado com a formação de um tumor é o gene de supressão tumoral, enquanto os produtos dos oncogenes favorecem a proliferação celular, o gene de supressão tumoral bloqueia o crescimento anormal. Sua contribuição para o processo de carcinogenese ocorre quando os dois alelos são perdidos, portanto age de forma recessiva (Sager, 1990).

Desta forma o mecanismo normal de divisão celular ocorre quando um protooncogene inicia o processo e é regulado por um gene de supressão tumoral. Se o protooncogene estiver ativado em oncogene ele irá propiciar uma proliferação celular tão grande que o gene de supressão tumoral não inibirá o processo. $O$ outro meio para a formação do tumor seria quando um proto-oncogene induz uma divisão celular normal, porém o gene de supressão tumoral não atua inibindo esta proliferação celular (Sager, 1990).

O gene da tríade da histidina frágil (FHIT) é um gene supressor de tumores envolvido em diferentes tipos de tumor entre eles o "tumor de pulmão de células não 
pequenas" (NSCLCs). Leel et al (2004) examinaram a deleção do alelo no locus do FHIT em 58 tumores primários do tipo NSCLCs. Foi encontrada uma perda de 87,7\%.

O gene P53 atua quando a célula sofre a ação de uma substância mutagênica. Células normais quanto ao P53 sofrem uma interrupção do processo de carcinogenese pois quando os níveis de P53 estão altos a célula alterada sofre reparação ou apoptose. Células com deficiência deste gene não interrompem o processo, o dano celular leva à células mutantes e posteriormente à células tumorais (Thompson,1993). Mutações e deleções de p53 são a lesão genética mais comum no câncer humano, uma incidência grandemente aumentada de câncer de pulmão ocorre em fumantes que sofrem da Síndrome de LiFraumeni, que é caracterizada pela inativação de um alelo p53. (De Flora et al., 2003) 


\title{
1.2.2. Carcinogênese ambiental:
}

O processo de formação de tumores é ativado pela exposição de uma célula normal à um agente químico, físico ou biológico capaz de provocar neoplasias. Quando um agente químico mutagênico entre em contato com a célula pode ocorrer sua excreção, inativação ou ativação. A ativação da célula normal leva à alterações genéticas. A célula iniciada tem uma lesão do DNA. Ocorre então uma expansão clonal seletiva, é a promoção que origina uma lesão pré-neoplásica. Neste momento a proliferação celular aumenta e a apoptose diminui. Novas alterações genéticas levam à ativação de proto-oncogenes ou à inativação de genes supressores de tumor. Ocorre a progressão originando um tumor maligno caracterizado por aneuploidia, e a manifestação do câncer clínico com sinais e sintomas.(Sociedade Brasileira de Mutagênese, Carcinogênese e Teratogênese Ambiental, on line)

\section{ATIVAÇÃo}

\author{
INICIAÇÃO
}

\author{
PROMOÇÃO
}

\section{PROGRESSÃO}

\section{MANIFESTAÇÃO}




\subsubsection{Classificações de Carcinógenos:}

Os cancerígenos são classificados de acordo com as evidências científicas de sua potencialidade em causar neoplasias em humanos. O IARC (on line) classifica estas substâncias em 5 grupos:

1. O agente é carcinógeno, existem evidências científicas suficientes em humanos. Alguns exemplos são o arsênico, o benzeno, aflatoxina e o estrógeno.

2. A- O agente é provável carcinógeno, existem evidências limitadas em humanos porém suficientes em animais. Exemplos do grupo 2 A são o benzo[a]antraceno e a sacarina sódica.

B- O agente é um possível carcinógeno, existem evidências limitadas em humanos ou inadequadas em humanos porém suficientes em animais, neste grupo estão incluídos o TCDD e a uretana.

3. O agente não é classificável como carcinógeno, existem evidências inadequadas em humanos, um exemplo é o diazepam.

4. O agente é provavelmente não carcinogênico, as evidências são inadequadas para animais.

A ACGIH (1999) classifica os carcinógenos em:

- A 1- Carcinogênico Humano Confirmado, o agente é carcinogênico para humanos confirmado em estudos epidemiológicos.

- A 2- Carcinogênico Humano Suspeito, dados obtidos com seres humanos indicam que o agente é carcinogênico, porém estes dados são conflitantes ou são insuficientes para confirmar o agente como carcinogênico para o homem; ou o agente é carcinogênico em experimentos animais, à níveis de dose, por via de administração e tipo histológico, ou 
por mecanismos que possam ser considerados relevantes quanto a exposição de trabalhadores. Os estudos epidemiológicos existentes são conflitantes ou insuficientes para confirmar o aumento de risco de câncer em seres humanos.

- A 3- Carcinogênico Animal, com desconhecida relevância para humanos o agente é carcinogênico em experimentos em animais, em doses altas por vias não consideradas relevantes para exposição humana. Os estudos epidemiológicos disponíveis não confirmam o aumento de risco para câncer em humanos expostos. As evidências disponíveis não sugerem que este agente seja um causador provável de câncer em seres humanos, exceto sob condições excepcionais de via de ingressono organismo ou de nível de exposição.

- A 4- Não Classificável como Carcinogênico Humano, agentes sob suspeita de serem carcinogênicos humanos ,porém os dados existentes são insuficientes para se chegar à esta conclusão. Experiências de laboratório ou estudos com animais não dão indicações de carcinogenicidade suficiente para classificar o agente em uma das outras categorias.

- A 5- Não Suspeito como Carcinogênico Humano, com base em pesquisas epidemiológicas bem conduzidas o agente não é suspeito de ser carcinogênico. O estudo deve conter histórias suficientes de de seguimento da exposição por longo período, doses suficientes, e controle estatístico adequado para concluir que a exposição ao agente não conduz à um risco significativo de câncer para humanos.

As substâncias para as quais não se dispõe de dados são consideradas não carcinogênicas.

A tabela 5 apresenta a classificação dos cancerígenos químicos baseados nos efeitos de iniciação e promoção da carcinogenicidade. 
Tabela 5: Classificação dos cancerígenos pelo efeito iniciador ou promotor de neoplasias.

\begin{tabular}{|c|c|c|c|}
\hline $\begin{array}{c}\text { EFEITO } \\
\text { INICIADOR }\end{array}$ & $\begin{array}{c}\text { EFEITO } \\
\text { PROMOTOR }\end{array}$ & CLASSIFICAÇÃO & $\begin{array}{c}\text { CARCINOGENICI } \\
\text { DADE }\end{array}$ \\
\hline Forte & Forte & $\begin{array}{l}\text { Cancerigeno } \\
\text { Primário }\end{array}$ & +++ \\
\hline Forte & Fraco & $\begin{array}{l}\text { Cancerígeno } \\
\text { Primário }\end{array}$ & ++ \\
\hline Forte & Nulo & $\begin{array}{l}\text { Iniciador } \\
\text { Puro }\end{array}$ & +1 \\
\hline Fraco & Forte & $\begin{array}{l}\text { Cancerígeno } \\
\text { Primário }\end{array}$ & ++ \\
\hline Fraco & Fraco & $\begin{array}{l}\text { Cancerígeno } \\
\text { Primário }\end{array}$ & + \\
\hline Fraco & Nulo & $\begin{array}{l}\text { Iniciador } \\
\text { Puro }\end{array}$ & +1 \\
\hline Nulo & Forte & $\begin{array}{l}\text { Cancerigeno } \\
\text { Secundário }\end{array}$ & + \\
\hline Nulo & Fraco & $\begin{array}{l}\text { Cancerígeno } \\
\text { Secundário }\end{array}$ & + \\
\hline Nulo & Nulo & $\begin{array}{c}\text { Não } \\
\text { Cancerígeno }\end{array}$ & 1 \\
\hline
\end{tabular}

Fonte: Curso de Carcinogénese e Mutagênese Ambiental (SBMCTA), 2003. 


\subsection{Classificação e Características dos Principais Poluentes:}

Como explanado acima algumas substâncias podem interagir no organismo levando à formação do tumor. Estudos indicam que a poluição do ar seja um fator de risco para neoplasias, em especial aquelas do trato respiratório (Pope et al, 2002, Cangerana-Pereira, 2000).

Pela característica de mistura da poluição do ar seu potencial formador de tumores estará ligado à composição da poluição de uma determinada região e às concentrações dos poluentes ali encontrados. Uma questão relevante é determinar se existe predominância de uma das frações de poluição no processo de mutagênese e carcinogênese ou se ambas, gases e partículas, atuam de forma sinérgica. Abaixo estão listados alguns dos poluentes conhecidos e/ou monitorados, suas características, concentrações encontradas atualmente na atmosfera paulistana e o estágio de conhecimento de seu potencial carcinogênico pelo IARC e pela ACGIH. É importante ressaltar que muitas substâncias presentes no ar atmosférico não foram estudadas e não são conhecidas. 


\subsubsection{Ozônio:}

O ozônio troposférico é formado a partir de uma série de reações químicas catalisadas pelo sol, envolvendo os hidrocarbonetos e os óxidos de nitrogênio. Seus níveis podem ser mais altos nas regiões periféricas dos grandes centros urbanos, acompanhando os ventos.(Tuomi et al, 2000). No Município de São Paulo seu padrão é ultrapassado com freqüência. Os meses de maio à julho são os que apresentam menor número de ultrapassagens, o mês de outubro apresentou as maiores concentrações deste poluente (CETESB , 2004)

O ozônio é absorvido praticamente em todo trato respiratório, mas os danos pulmonares são de grande preocupação devido a suscetibilidade desta região em desenvolver doenças crônicas e por que uma fração significante do ozônio atinge região alveolar. O trato respiratório é uma estrutura complexa e o $\mathrm{O} 3$ pode causar danos celulares. Os alvos do ozônio no pulmão são os ácidos graxos e as proteínas das membranas celulares, estes danos causam disfunções e até mesmo a morte celular. (Kley et al. 1999) Em um estudo de coorte, envolvendo 6.338 adultos da Califórnia - EUA foi encontrado um aumento do risco relativo para câncer de pulmão nos expostos ao ozônio. (Beeson et al, 1998) O ozônio não se encontra classificado como carcinogênico humano tanto pela ACGIH (2001) como pela WHO/IARC (2002). 


\subsubsection{Dióxido de Enxofre}

As principais fontes emissoras de dióxido de enxofre são os processos de queima de combustíveis fósseis, especialmente carvão e óleo derivado do petróleo, em fontes fixas (termelétricas e indústrias) e nas fontes móveis. $\mathrm{Na}$ atmosfera $\mathrm{o} \mathrm{SO}_{2}$ pode ser oxidado a ácido sulfúrico, aumentando a acidez da chuva.

Com o aumento do controle da emissão industrial na década de 1980, os níveis deste poluente tiveram um sensível diminuição e passaram a atender o padrão de qualidade do ar primário na região metropolitana de São Paulo e no ano 2000 esteve próximo de alcançar o padrão secundário (CETESB,2001). Em 2003 o padrão secundário não foi ultrapassado em nenhuma estação de monitoramento (CETESB, 2004).

Boa parte do $\mathrm{SO}_{2}$ inalado por uma pessoa em repouso é absorvida nas vias aéreas superiores, a atividade fisica potencializa esta absorção fazendo com que ela ocorra também em regiões mais profundas do pulmão. Sua eliminação é feita pela expiração e pela urina. $\mathrm{O} \mathrm{SO}_{2}$ não se encontra classificado como carcinogênico humano tanto pela ACGIH (2001) como pela WHO/IARC (2002). 


\subsubsection{Monóxido de Carbono}

As principais fontes emissoras são os processos de combustão, em especial os veículos automotores. Em São Paulo, na década de 1970, 1980 e início da década de 1990 a concentração de monóxido de carbono excedia freqüentemente os padrões estabelecidos, bem como o nível de atenção (CETESB,2001). No ano de 2003 o padrão de 8 horas de CO foi excedido em 4 estações de monitoramento, a estação que apresentou concentrações acima do padrão com mais freqüência foi a estação de São Caetano do Sul (10 dias). O padrão de 1 hora não foi ultrapassado e o nível de atenção não foi excedido nenhuma vez (CETESB, 2004).

Uma vez inalado, o monóxido de carbono produz uma ligação estável com a hemoglobina, formando a carboxiemoglobina e o acúmulo desta diminui o transporte de oxigênio para os tecidos. $\mathrm{O} C \mathrm{CO}$ não está classificado como carcinogênico tanto pela ACGIH (2001) como pela WHO/IARC (2002) 


\subsubsection{Oxidos de Nitrogênio}

Os principais representantes da família dos óxidos de nitrogênio (NOx ) são o óxido nítrico (NO) e o dióxido de nitrogênio ( $\mathrm{NO} 2$ ). As fontes emissoras desses poluentes, mais importantes nos centros urbanos, são os veículos automotores pois eles são oriundos principalmente da combustão. Estes compostos, na presença de oxigênio, hidrocarbonetos e luz solar possibilitam a formação de ozônio, e outros oxidantes fotoquímicos na atmosfera.

Dentre os óxidos de nitrogênio, o dióxido de nitrogênio foi escolhido como parâmetro indicador de qualidade do ar. Em São Paulo os níveis do $\mathrm{NO}_{2}$ atmosférico ultrapassavam freqüentemente o padrão de qualidade do ar, sendo considerado um marcador específico de emissão veicular (CETESB,2001). No ano de 2003 não houveram ultrapassagens do padrão anual (CETESB, 2004).

Devido a sua baixa solubilidade, quando inalado, $\mathrm{o} \mathrm{NO}_{2}$ atinge porções periféricas do pulmão. É um agente oxidante, ou seja, é capaz de promover a oxidação de substratos orgânicos pela captura de um elétron da molécula. (EVANS et al ,1973). O NO e o $\mathrm{NO}_{2}$ não estão classificados como carcinogênicos humanos pela ACGIH (2001) e pela WHO/IARC (2002). 


\subsubsection{Compostos Orgânicos:}

\section{Hidrocarbonetos}

Nos centros urbanos são originários principalmente da combustão incompleta, em especial de veículos leves (automóveis, camionetas, etc.), da volatilização de solventes orgânicos e do processamento e do armazenamento do petróleo e de seus derivados. A toxicidade destes poluentes dependerá de cada tipo de composto, sendo que alguns são cancerígenos.

De forma indireta os hidrocarbonetos são também importantes, pois participam da reação fotoquímica, produzindo outros compostos agressivos a saúde como os aldeídos e o peroxiacetilnitrato (PAN) e o ozônio troposférico na reação com os óxidos de nitrogênio, sob ação da luz solar. (ASSUNÇÃO, 1998)

Colón et al. (2001) realizaram medições de compostos orgânicos no Município de São Paulo em 1998 em seis pontos. Os níveis de hexano, heptano, benzeno, tolueno, etilbenzeno, m,p-xileno, o-xileno e 1,3,5-TMB foram comparados com dados coletados em Caracas, Quito, Santiago, Bangkok, e Manila; e com dados coletados em São Paulo em 1995. Os resultados obtidos no túnel Daher E. Cutait ( 9 de julho), situado na região central de São Paulo, levaram à conclusão de que o controle desses compostos deve ser feito primariamente nos veículos.

Segundo a ACGIH (2001), e a WHO/IARC (2002) o benzeno é carcinogênico humano confirmado. O tolueno e o xileno estão classificados como A4 (não-classificável como carcinogênico humano) pela ACGIH (2001) e como Grupo 3 (não-classificável como 
carcinogênico humano) pela WHO/IARC (2002). O etilbenzeno está no Grupo 2B (possível carcinogênico humano) da WHO/IARC (2002)

\section{Dioxinas e Furanos}

As dibenzo-p-dioxinas policloradas e os dibenzo-furanos policlorados, apresentam um grande número de congêneres: 75 para dioxinas e 135 para furanos. São formados como subprodutos de processos industriais que envolvam cloro. Não ocorrem naturalmente. As fontes de PCDD ( dioxinas ) e PCDF ( furanos ) podem ser divididas em dois grandes grupos: produtos químicos e processos de combustão (incineradores de lixo municipais, incineradores de resíduos industriais, de serviços de saúde etc.) (Assunção \& Pesquero, 1999).

Assunção et al. (2005) mediram dioxinas e furanos nos anos de 2000 e 2001 . Foram encontradas concentrações relativamente altas destes poluentes na atmosfera da cidade de São Paulo, a maior média de concentração deu-se no ponto de coleta onde existe influência de fontes industriais e grande volume de veículos leves e pesados circulando (Lapa).

Dezessete compostos destacam-se quanto à toxicidade, sendo as que apresentam substituições nas posições de número $2,3,7$ e 8; a 2,3,7,8-tetraclorodibenzo-p-dioxina é de maior interesse do ponto de vista toxicológico. As TCDDs estão classificadas pela USEPA no grupo B1, provável carcinogênico humano. (USEPA/SAB, 1995 in Ribeiro \& Assunção, 2002) e como Grupo 1 pela WHO/IARC (2002) (carcinogênico humano confirmado). Várias outras dioxinas estão listadas pela WHO/IARC (2002) como potenciais carcinogênicos, sendo que os furanos estão listados no Grupo 2B (possível carcinogênico humano). 


\section{Hidrocarbonetos Policíclicos Aromáticos}

Os HPAs compreendem uma série de compostos, 17 deles são considerados prioritários. São eles: naftaleno, acenaftileno, acenafteno, fluoreno, fenantreno, antraceno, fluoranteno, pireno, benzo[a]antraceno, criseno, benzo[b]fluoranteno, benzo[k]fluoranteno, benzo[a]pireno, benzo[e]pireno indeno[1,2,3 cd] pireno, dibenzo[ah]antraceno e benzo[ghi]perileno.

As principais fontes são as emissões industriais, queimadas e os veículos (Pesquero, 2001). São compostos que oferecem riscos para a saúde humana e muitos deles são reconhecidos como agentes carcinogênicos (IARC, 2002). HPAs representam o maior grupo de poluentes genotóxicos orgânicos gerado pela combustão e processamento de combustíveis fósseis (Hemminki et al, 1999).

Os hidroarbonetos policíclicos aromáticos foram medidos por Fernandes et al (2002) na Cidade do Rio de Janeiro. Os níveis dos HPAs diminuem significativamente com a distância das vias de tráfego mais intenso demonstrando que as fontes móveis são importantes na emissão deste tipo de poluente no Município em estudo. Pereira et al (2002) mediram HPAs em Salvador (BA), as concentrações foram semelhantes às encontradas em Kurashiki no Japão e Berkeley nos EUA.

Medeiros et al (2004/2004) mediram HPAs no sedimento marinho nas cidades de Santos e São Sebastião (SP). As concentrações encontradas foram associadas a atividade antropogênica relacionada ao terminal marítimo da Petrobrás (São Sebastião) e ao complexo industrial de Cubatão (com influência em Santos). 
Classificações de alguns HPAs segundo a ACGIH (2001): A2, carcinogênico humano suspeito: Benzo[a]antraceno, Benzo[a]pireno e dibenzo[ah]antraceno; A3,carcinogênico animal: criseno; A4, não-classificável como carcinogênico humano: naftaleno. Os demais HPAs não foram classificados pela ACGIH (2001). Segundo a WHO/IARC (2002), estão classificados como Grupo 2A (provável carcinogênico humano) o Benzo[a]antraceno, Benzo[a]pireno e o dibenzo[ah]antraceno; Grupo 2B (possível carcinogênico humano): dibenzo[ah]antraceno, indeno[1,2,3 cd] pireno e no Grupo 3 (não classificável como carcinogênico humano: fluoreno, antraceno, pireno, criseno e benzo[ghi]perileno.

Historicamente os níveis de HPAs foram estimados através dos niveis de outros poluentes como poeira e material particulado em suspensão (Hemminki et al, 1999).

Resultados de efeitos mutagênicos e carcinogênicos dos HPAs foram obtidos através de modelos experimentais com bactérias, animais de laboratório e testes in vitro com tecidos humanos, contudo os resultados ainda são incompletos. Devido a inexistência e estudos sistemáticos sobre efeitos de HPAs na saúde humana ainda não foram estabelecidos padrões de qualidade para estes poluentes (Pesquero, 2001).

Entre os compostos pertencentes à classe dos HPAs, aqueles que apresentam maior peso molecular (302) são considerados relevantes indutores de neoplasias (Sauvin, 2004)

\section{Outros Compostos Orgânicos}

Entre os outros compostos destacam-se os aldeídos. O formaldeído recebe classificação A2 (carcinogênico humano suspeito) pela ACGIH (2001) e Grupo 2A pela 
WHO/LARC (2002) e o Acetaldeído recebe classificação A3 (carcinogênico animal) da ACGIH (2001) e 2B pela WHO/IARC (2002).

Colón et al (2001) realizou estudo na Região Metropolitana de São Paulo objetivando identificar e quantificar compostos orgânicos associados com as emissões dos combustíveis utilizados neste Município, e verificar o potencial de exposição humana. Este estudo demonstrou que entre os compostos orgânicos presentes na atmosfera paulistana existe um predomínio do metanol e 1- e 2-etanol, em níveis acima dos encontrados nas cidades norte americanas. As concentrações médias de substâncias aromáticas são entre 2 e 3 vezes maiores, aldeídos voláteis são entre 5 e 10 vezes maiores e álcoois são 10 a 100 vezes maiores que os níveis encontrados em Los Angeles em um estudo da Environmental Protection Agency (EPA), este fato possivelmente é devido à adição de etanol na gasolina no Brasil. Para realização deste trabalho foram estudadas 6 regiões de São Paulo: Cerqueira César, Parque do Ibirapuera, Lapa, Congonhas, Parque D. Pedro, e Túnel 9 de Julho. O Túnel foi o ponto de coleta que apresentou maiores níveis de substâncias, neste ponto nalcanos, n-aldeídos, benzeno, tolueno, e m,p xileno excederam a média de concentração do estudo. A região do Parque D. Pedro apresentou as médias mais baixas. Os demais pontos de coleta demonstraram níveis semelhantes de concentração entre si (Colón, 2001). Na região de Cerqueira César as maiores concentrações foram de metanol e pentanol. 


\subsubsection{Material Particulado}

É composto de uma série de partículas sólidas e líquidas suspensas no ar. As principais fontes são os processos de combustão (indústrias e veículos automotores) e aerossol secundário formado na atmosfera. Sua origem entre outras, é a combustão, a dispersão de partículas do solo e materiais biológicos como pólens e esporos; partículas com diâmetro menor que $2,5 \mu \mathrm{m}$ são denominadas finas, derivam, entre outras fontes, da combustão em veículos automotores, incineradores e termelétricas.

Partículas com diâmetro aerodinâmico equivalente menor ou igual a $10 \mu \mathrm{m}$ são capazes de atingir, com maior probabilidade, as vias respiratórias inferiores, sendo importante o seu controle. A Environmental Protection Agency (EPA) dos Estados Unidos da América dedica especial atenção ao controle do material particulado fino. Foram relatados efeitos mutagênicos deste poluente na atmosfera paulistana por Batalha e colaboradores em 1999.

A exposição prolongada ao material particulado é um importante risco ambiental para mortalidade por doenças cardiovasculares e por câncer de pulmão (Pope et.al., 2002).

Embora muitos poluentes tenham sido associados com efeitos adversos, provavelmente o componente com maior impacto em saúde pública seja o material particulado. Esta mistura complexa de poluentes sólidos e liquidos inclui materiais orgânicos, sulfatos, nitratos, outros sais, metais e materiais biológicos. Muitos carcinógenos, incluindo HPAs, adsorvem nas partículas e podem ser depositados no trato respiratório. Com propósitos de pesquisa o material particulado é dividido em PM10 (partículas inaláveis), PM 2,5 (partículas finas) e PM 0,1 (partículas ultrafinas). Estes tipos 
de cortes geralmente representam diferenças nas fontes e estão associados a diferentes propriedades físico-químicas. As características físico-químicas responsáveis pela toxicidade associada ao PM não estão completamente compreendidas. Por exemplo, a contribuição relativa do tipo de partícula, número, massa, superficie e composição química não foram determinadas. Para uma dada concentração de massa, o corte vai determinar ambos, número e superficie; por exemplo podemos tomar uma concentração de massa de $10 \mu \mathrm{g} / \mathrm{m} 3$, uma partícula de diâmetro de $2 \mu$ corresponde a 1,2 partícula/ml de ar com uma superfície de $24 \mu 2$, enquanto uma partícula de diâmetro de $0,02 \mu$ corresponde a 2,4 milhões partículas $/ \mathrm{ml}$ com uma superficie de $3.000 \mu 2$. Uma grande superficie significa grandes exposições a agentes carcinogênicos, como os HPAs adsorvidos nas partículas (Vineis et al, 2004)

No Município de São Paulo, a média diária do padrão de qualidade do ar para partículas inaláveis é ultrapassada e durante o inverno também o nível de atenção. A média aritmética anual foi ultrapassada em 9 estações, entre elas a estação de Cerqueira César (Cetesb, 2004). 


\subsection{Poluição e saúde}

Efeitos adversos da poluição do ar têm sido vastamente documentados nas últimas décadas. Os primeiros sintomas de que o ar poluído teria conseqüências sobre a saúde da população foram os episódios de aumento de mortalidade em regiões de grande concentração de poluentes, em períodos desfavoráveis para sua dispersão.

No Município de São Paulo foram documentados efeitos agudos da poluição do ar, como o aumento dos casos de doenças respiratórias em idosos e crianças e a mortalidade intrauterina em dias de altos níveis poluição do ar e de condições atmosféricas desfavoráveis à sua dispersão. (Saldiva et al, 1994; Saldiva et al, 1995 e Pereira et al, 1998)

No inverno, freqüentemente ocorrerem dias com baixa umidade do ar e alta concentração de poluentes. Nessas condições, é comum ocorrerem complicações respiratórias devido ao ressecamento das mucosas, provocando sangramento pelo nariz, ressecamento da pele e irritação dos olhos (CETESB, 2003).Outro fator a ser considerado é que as emissões causam grande incômodo aos pedestres próximos às vias de tráfego. No caso da fuligem (fumaça preta), a coloração intensa e o profundo mau cheiro desta emissão causa de imediato uma atitude de repulsa e pode ainda ocasionar diminuição da segurança e aumento de acidentes de trânsito pela redução da visibilidade.

O Vale Utah, nos Estados Unidos, apresenta condições únicas para a realização de estudos com material particulado. Os moradores são, em sua maioria, mórmons e portanto não fumantes. A região apresenta altas concentrações de PM10 devido à condições climáticas e geográficas. Os níveis dos demais poluentes são relativamente baixos. Pope (1996) realizou estudo epidemiológico nesta região e observou que altas concentrações de PM10 estão associadas à aumento de doenças respiratórias, das ausências escolares, das 
admissões hospitalares e da mortalidade, em especial por doenças respiratórias e cardiovasculares. Em estudo de revisão comentada realizada com dados da mesma região Ghio (2004) cita mudanças nos padrões de morbi mortalidade associadas aos níveis de material particulado.

Nafstad et al (2004-1) também encontrou aumento da mortalidade por doenças respiratórias. Em seu estudo foi investigada a associação entre as causas de mortalidade e medidas individuais de exposição aos poluentes do ar em uma coorte de homens noruegueses seguidos de 1972 à 1998. Os resultados indicam que a exposição à poluição do ar aumenta a mortalidade geral, a associação é mais forte com as doenças respiratórias. Foram encontrados também efeitos cardiovasculares. Em outro estudo Nafstad (20042)considera que de maneira geral a fração particulada da poluição do ar parece ser a responsável pelos efeitos adversos à saúde. $\mathrm{O}$ autor cita ainda o fato de que existem poucos estudos noruegueses e que em seu país são considerados os resultados de estudos de outros locais com diferentes composições e concentrações de poluentes do ar.

A associação entre material particulado fino e pressão sangüínea foi estudada em 631 visitas de pacientes cardiopatas em reabilitação em Boston, EUA. Zanobetti et al (2004) concluiram que pacientes com doença cardíaca pré existente têm o risco de morbimortalidade aumentados pela fração particulada da poluição. Este risco é manifestado pelo aumento da pressão sangüínea periférica.

Peters et al (2004) afirmam que uma associação entre exposição ao tráfego de veículos e aumento na incidência de doenças cardiovasculares foi sugerida em diversos estudos. Com base neste fato o grupo buscou averiguar se a exposição ao tráfego de veículos poderia alavancar infartos do miocárdio. Casos de infarto do miocárdio foram 
identificados entre fevereiro de 1999 e julho de 2001. O tempo que os pacientes passaram em carros, transporte público, bicicletas e motocicletas está fortemente associado com o aumento dos casos de infarto.

Kappos et al (2004) em estudo de revisão da Comissão Alemã de Prevenção à Poluição do ar demonstraram que a exposição ao material particulado está associada ao aumento da mortalidade total, cardiovascular e infantil. Com respeito à morbidade, sintomas respiratórios e o sistema imune são afetados. Pacientes com asma, pneumonia e outras doenças respiratórias pré existentes estão mais sujeitos ao efeitos deletérios da poluição na saúde, assim como aqueles portadores de doenças cardiovasculares.

Petroeschevsky et al (2001) estudaram as admissões hospitalares na Austrália e sua correlação com os poluentes. O ozônio foi consistentemente associado com internações por asma e doenças respiratórias. A fração particulada tem boa associação com internações pelas mesmas causas contudo tem associação negativa com doenças cardiovasculares.

Baseados em diversos episódios de severa poluição do ar foi estabelecida uma correlação temporal entre altas concentrações de $\mathrm{PM} 10$ e $\mathrm{SO}_{2}$ aumento da mortalidade por causas agudas respiratórias e cardiovasculares em Viena na Áustria nos anos 1970. Com as reduções dos níveis dos poluentes nos anos 1980 a associação deixou de ser documentada com o material particulado e $\mathrm{SO}_{2}$, porém os poluentes relacionados ao tráfego de veículos (particulado fino e Nox) permaneceram um problema de saúde pública nas cidades austríacas. Diversos estudos visando analisar efeitos crônicos da poluição atmosférica tem sido realizados, incluindo uma coorte de nascimentos na cidade de Linz. Muitos efeitos agudos foram estabelecidos entre eles dispnéia e tosse noturna em crianças com asma. 
Entretanto pouco foi demonstrado quanto aos efeitos crônicos como câncer (Neuberger \& Moshammer, 2004).

Utilizando dados de uma coorte para riscos de arteriosclerose foram avaliados marcadores hemostáticos e inflamatórios e sua associação com os poluentes de critério. Os fatores analisados foram fibrinogênio, fator VIII-C, fator von Willebrand, albumina e contagem de glóbulos brancos. Foi utilizada regressão linear para ajustar para fatores de risco para doença cardiovascular, variáveis sócio-econômicas e demográficas, e variáveis meteorológicas relevantes. Este estudo sugere que os marcadores hemostáticos e inflamatórios analisados estão adversamente associados com os poluentes (Liao et al, 2004).

Exercícios aeróbicos regulares estão entre as práticas recomendadas pelos médicos para melhorar a saúde e aumentar a expectativa de vida. Em grandes cidades os exercícios são praticados em locais poluídos com gases e partículas associados a efeitos agudos e crônicos. Uma vez que os exercícios amplificam a tomada de ar, pessoas que os praticam em locais poluídos aumentam seu risco (Sharman, 2004).

Visando analisar os efeitos da poluição na morbidade infantil Bakonyi et al (2004) utilizaram dados de atendimento por causas respiratórias em crianças na cidade de Curitiba, Paraná, Brasil. Foram estudados $\mathrm{PM} 10$, fumaça, $\mathrm{NO}_{2}$ e $\mathrm{O}_{3}$. Todos os poluentes estudados apresentaram um efeito nas doenças respiratórias infantis. Os resultados sugerem que a poluição promove efeitos adversos na saúde respiratória de crianças mesmo quando os níveis dos poluentes estão abaixo do padrão de qualidade do ar.

O efeito da poluição nas ausências escolares foi estudado também na Califórnia, EUA. Rondeau et al (2004) propõe um modelo estatístico binário em três níveis para 
examinar simultaneamente a exposição diária aos poluentes, o fator de risco individual e um terceiro fator ou o tempo. Foi levado em consideração que o evento de um dia está associado aos dias que o precederam.

Pacientes com doenças alérgicas das vias respiratórias podem ter seus sintomas agravados tanto pela fração gasosa quanto pela fração particulada da poluição do ar (Bernstein et al, 2004).

A produção de citocinas pelo baço e nódulos linfáticos em camundongos expostos à material poluente em suspensão foi utilizada na investigação conduzida por Drela et al (2002). A produção de citocinas foi determinada pela porcentagem de células positivas para citocina intracelular e pela concentração de citocina na cultura. Foram utilizados dois modelos experimentais, um grupo recebeu o poluente vis injeção peritonial e outro grupo recebeu a suspensão oral. A expressão de citocina intracelular e os níveis secretados parecem ser bons métodos para avaliar a função do sistema imune com relação à exposição à poluição atmosférica. Dois tipos de citocina foram avaliados IL2 e IL4. A exposição prolongada aumentou a produção de IL2 em machos e fêmeas e de IL4 em machos.

O potencial imunotóxico sistêmico da exposição respiratória ao material particulado emitido pela combustão de óleo diesel foi estudado por Yang et al (2003). Camundongos fêmeas com 8 semanas foram expostas à concentrações de partículas de diesel intratraqueal 3 vezes a cada 2 semanas, as concentrações foram aumentadas ao longo do tempo. Os camundongos foram sacrificados com 2 ou 4 semanas de exposição. Camundongos expostos ao particulado da emissão de diesel ( 1 à $15 \mathrm{mg} / \mathrm{kg}$ de peso) não apresentaram aumento de peso do baço ou fígado. Os pulmões apresentaram aumento de peso. Os parâmentros hematológicos não apresentaram alterações significantes, exceto uma 
diminuição na contagem de plaquetas. Quanto à ação no sistema imune foi possível detectar uma diminuição na produção de $\operatorname{IgM}$ e uma diminuição do número total de células do baço em relaçõa ao número total de células $\mathrm{T}$ enquanto o número de células $\mathrm{B}$ não foi alterado. Os autores concluíram que a exposição ao particulado originado de diesel resultou em uma imunossupressão sistêmica.

Material particulado presente no meio ambiente pode aumentar a resposta alérgica nas vias respiratórias aumentando a resposta imune a células Th2 com conseqüente redução da resposta Th1. A infecção respiratória bacteriana está relacionada com as células Th1. Desta forma animais infectados responderiam de formas diferentes à infecção se expostos à poluição. Para verificar esta hipótese Steerenberg et al (2004) examinaram o efeito da exposição ao material particulado urbano e diesel em ratos infectados com Listeria monocytogenes. Os resultados não apresentaram diferanças entre o número de bactérias nos ratos expostos e nos animais controle. Em conclusão, este estudo não encontrou evidências de que a exposição ao material particulado possa afetar a resistência a infecções bacterianas.

Motores à diesel emitem partículas que podem ser inaladas e depositadas na superficie pulmonar. A preocupação com a carcinogenicidade das partículas é devida aos compostos orgânicos que podem ser extraídos das mesmas e apresentam grande atividade mutagênica. Contudo o potencial carcinogênico das emissões dos motores movidos à óleo diesel gera controvérsias. Valberg \& Watson (1999) compararam a atividade mutagênica pulmonar do condensado de fumaça de cigarro com extrato de partículas emitidas por motores à diesel. A magnitude da atividade mutagênica foi similar para ambos. Tanto para fumaça de cigarro quanto para partículas da queima do diesel mutações em tecidos alvo são 
possíveis. Os autores assumem que o risco provocado por fumar 1 cigarro seja equivalente a exposição em níveis ambientais por 1 ano ao material particulado originado da queima do óleo diesel.

O potencial mutagênico do extrato orgânico das partículas da combustão do óleo diesel também foi estudado por Rivedal et al (2003). Foi extraído material orgânico das partículas por diclorometil. Depois de extraído este material foi fracionado em 5 alícotas: hidrocarbonetos alifáticos, hidrocarbonetos policíclicos aromáticos, nitro-HPAs, dinitroHPAs e compostos polares. Para avaliar o potencial mutagênico foi utilizado o teste de Ames em Salmonella typhimurium e o teste de inibição de "gap junction intercellular communication" (GJIC), este teste está associado com efeito de promoção de tumores e carcinógenos não genotóxicos enquanto o teste de Ames é aceito como screening para substâncias com atividades genotóxicas. O maior potencial mutagênico encontrado foi da fração nitro-hidrocarbonetos policíclicos aromáticos, seguido pelo dinitro-hidrocarbonetos policíclicos aromáticos. O efeito no GJIC foi à fração contendo compostos polares, seguida pelas dinitro-HPAs.

Jadczyk (2001) coletou amostras de partículas em Wroclaw na Polônia durante os meses de inverno e verão. Compostos orgânicos adsorvidos nas partículas foram extraídos por 8 horas. As concentrações de HPAs e benzo[a]pireno foram determinadas. A concentração de material particulado ficou entre 17 e $144 \mathrm{mg} / \mathrm{m} 3$, os compostos orgânicos adsorvidos nas partículas apresentaram concentrações entre 1,1 e $28,6 \mathrm{mg} / \mathrm{m} 3$. A concentração dos HPAs (lista EPA) ficou entre 8,3 e $1211,6 \mathrm{ng} / \mathrm{m} 3$, a de benzo[a]pireno entre 4,5 e $709 \mathrm{ng} / \mathrm{m} 3$. Mutagenicidade das partículas foi avaliada pelo teste de Ames. O material coletado em diferentes localidades de Wroclaw apresentou atividade mutagênica. 
Danos oxidativos do DNA podem estar envolvidos no risco aumentado de câncer associado com exposição à poluição do ar, que contém inúmeras substâncias oxidantes.CYP1A2 é induzida e metabolizada por HPAs e aminas aromáticas e pode modificar o efeito de exposição à poluição ambiental. Da mesma forma o reparo do DNA pode ser influenciado pela exposição ocupacional, ou outra, assim como modifica o efeito do agente causador do dano. 57 motoristas de ônibus não fumantes foram investigados quanto à exposição genotóxica ao diesel na região metropolitana de Copenhagen. Os motoristas foram estudados em um dia de trabalho e um dia de folga. Comparações foram feitas entre os que dirigiram na área urbana e na área rural. A taxa de dano oxidativo do DNA foi estimada para a excreção de 24 horas de 8-oxo-2'-deoxiguanosina (8-oxodG), um produto de reparo. A atividade de CYP1A2 foi estimada através da excreção dos metabólitos de cafeína. O reparo de DNA foi estimado pelo desarranjo na síntese de DNA em células isoladas em um dia de trabalho. Em um dia de trabalho a excreção de 8-oxodG foi maior para os motoristas da região central que para aqueles que dirigiram no campo, para este parâmetro não houve diferença entre dia de folga e dia de trabalho. CYP1A2 não foi afetada pela região de trabalho, porém correlaciona-se com 8-oxodG quanto ao status (folga ou não). O reparo de DNA não correlacionou-se nem com a região de trabalho nem com o status. O aumento na excreção de 8-oxodG na região central indica que a exposição ao ar poluido causa dano oxidativo no DNA (Loft et al, 1999).

Em um estudo experimental utilizando ratos Wistar, Pinho et al (2004) descreveram os efeitos agudos e crônicos da exposição aguda à cinza de carvão no parenquima pulmonar e o envolvimento de oxigênios reativos nos efeitos da cinza de carvão. Os ratos foram divididos em 4 grupos $48 \mathrm{~h}, 7$ dias, 30 dias, e 60 dias após a instilação. A cinza de carvão 
foi administrada diretamente nos pulmões por instilação intratraqueal, os animais controle receberam salina. A peroxidação de lipídeos foi analisada pela quantidade de espécies de ácido reativo tiobarbitur (TBARS), o dano oxidativo à proteína foi obtido pela determinação de grupos carbonil, o total do parâmetro antioxidante (TRAP) foi estimado pela emissão de quimioluminescência luminol. Atividade catalítica foi medida pela taxa de diminuição do peróxido de hidrogênio; a atividade da dismutase superoxido foi medida pela inibição da adrenalina autooxidação. Os resultados indicaram infiltração de inflamação após 48 h. de exposição. Inicialmente houve uma infiltração celular sugestiva de infiltração de linfócitos após 7 dias da exposição. Esta resposta inicial foi seguida por uma resposta inflamatória crônica caracterizada por agregados de macrófagos 30 dias após a exposição. Após 60 dias a resposta foi resolvida sendo similar à dos animais controles. Durante ambas as fases de inflamação, aguda e crônica< houve uma diminuição da TRAP em comparação aos animais controles. Houve ativação da dismutase superoxido 60 dias após a exposição. TBARS aumentou 60 dias após a exposição e os grupos carconil estiveram aumentados todo o período após a exposição. Este estudo sugere uma resposta inflamatória bifásica com envolvimento do dano oxidativo.

Jiang et al (2004) utilizou camundongos em estudo experimental para averiguar o papel do PM 2,5 na reação imune e no dano oxidativo. O estudo conclui que o PM2,5 tem efeitos tóxicos agudos nos tecidos e células pulmonares em camundongos através da imunotoxicidade e do stress oxidativo.

O risco genotóxico associado a exposição aos HPAs foi longamente avaliado nos últimos anos. Menos compreendidos é o potencial genotóxico do produto das reações atmosféricas desta classe de poluente. Grosovsky et al (1999) utilizando ensaios em células 
humanas avaliaram a genotoxicidade de naftaleno,fenatreno,e do produto de suas reações atmosféricas 1-nitronaftaleno, 2-nitronaftaleno (2-NN), 1-hidroxi-2NN, 2-hidroxi-1nitronaftaleno,1,4-naftoquinona, e 2 nitrodibenzopirano (2NDBP). Frações individuais foram testadas para efeito genotóxico, primariamente usando a linhagem de células humanas B linfoblastóides, MCL-5, e pelo teste de micronúcleos modificado CREST. Os resultados indicaram que $2 \mathrm{NN}$ e $2 \mathrm{NDBP}$ possuem o maior potencial mutagênico. $\mathrm{A}$ genotoxicidade destes compostos associada à suas altas concentrações atmosféricas demonstra a importância de considerar os produtos das reações atmosféricas dos HPAs quando tratamos de genotoxicidade ambiental.

A alta freqüência de micronúcleos em mucosa bucal de pacientes com tumores de laringe expostos a diferentes concentrações ambientais de poluentes indica que o estudo das células da mucosa bucal possa ser usado como indicador do risco de carcinogênese (Belowska et al, 2004).

Danos ao DNA foram estudados por Soares et al (2003). A exposição crônica à poluição do ar foi avaliada em roedores através do teste de micronúcleo. Camundongos foram expostos à atmosfera urbana de São Paulo (Brasil) por 120 dias e comparados com animais mantidos no campo por igual período (Atibaia). Os níveis dos poluentes (PM10, $\mathrm{Co}, \mathrm{NO}_{2}$ e So2) foram acompanhados diariamente em São Paulo. Em Atibaia foram feitas medições esporádicas de $\mathrm{CO}$ e $\mathrm{O} 3$, confirmando os resultados baixos. A exposição ao ar urbano poluído apresentou aumento na freqüência de micronúcleos. Houve associação entre os níveis dos poluentes na semana que precedia a coleta de sangue e a contagem de micronúcleos. A correlação entre poluentes e micronúcleos foi particularmente forte com os 
poluentes emitidos por fontes móveis. Os autores concluem que os níveis urbanos de poluição do ar podem causar mutações de células somáticas.

Com o objetivo de determinar o potencial genotóxico das emissões de um incinerador na região metropolitana de São Paulo, Ferreira et al (2000) o bio ensaio de pelo estaminal em tradescantia sp. Foi encontrada uma correlação positiva entre a distribuição espacial das emissões do incinerador localizado em região urbana e eventos mutagênicos medidos pelo ensaio de pelo estaminal.

Guimarães et al (2004) avaliaram a toxicidade das partículas menores que $10 \mu \mathrm{m}$ na região metropolitana de São Paulo, Brasil. Foram utilizados 4 grupos de Tradescantia sp : plantas cultivadas em Caucaia do Alto, plantas cultivadas em São Paulo, inflorescências coletadas em plantas cultivadas em Caucaia, trazidas para São Paulo e mantidas em câmara recebendo ar ambiente, e inflorescências coletadas em plantas cultivadas em Caucaia, trazidas para São Paulo e mantidas em câmara com filtro para material particulado. Foi realizado um estudo de mutações no pelo estaminal. A freqüência de mutações em Caucaia foi significantemente menor que nos demais grupos. Flores coletadas em Caucaia e trazidas para São Paulo, que receberam ar ambiente mostraram taxas de mutação semelhantes às de São Paulo. A filtragem das partículas reduziu as taxas de mutação. Estes resultados indicam que as partículas tem papel relevante no desenvolvimento de mutações dependentes da poluição.

A poluição ambiental por agentes genotóxicos implica em um aumento da taxa de mutações. Existem duas possibilidades quanto ao tipo de célula que sofre a mutação. Em células germinativas as mutações podem elevar as incidências de doenças genéticas nas 
próximas gerações. Em células somáticas o efeito adverso será o aumento do número de casos de câncer ( Hemmink et al, 1999). 


\subsubsection{Poluição do Ar e Câncer:}

A poluição do ar é fator de risco também para doenças crônicas, como tem sido constatado. Muitas substâncias são investigadas quanto ao potencial carcinogênico, entre elas ingredientes da dieta, produtos industriais e residuos tóxicos. $\mathrm{O}$ ar poluído é composto por uma série de substâncias que, segundo uma estimativa de Lewtas (1993), chega a 2800 compostos. Destas, apenas $10 \%$ foram estudadas quanto ao potencial efeito genético ou carcinogênico.

A alta incidência de Câncer de escroto em limpadores de Chaminé no século XVIII levou à percepção de que substâncias químicas poderiam atuar na formação dos tumores. Atualmente estima-se que $90 \%$ dos casos de câncer estejam relacionados de foram direta ou indireta ao meio ambiente. (Pupo Nogueira, 1983)

Estudo realizado por Reymão et. al. (1997) em camundongos tratados com uretana e expostos à poluição do ar do Município de São Paulo, demonstrou uma maior incidência de transformação neoplásica em tecido pulmonar, comparada à dos controles mantidos em local não poluído. A poluição causou um aumento dose-dependente significativo na indução de câncer pela uretana. Cury et al. (2000), em um estudo semelhante, observaram um aumento da poliploidia nos tumores após seis meses de exposição.

Diversos autores tem encontrado relação entre poluição do ar e câncer, em especial com a neoplasia pulmonar(Harvard Report on Cancer, 1996; Katsouyanni \& Pershagen, 1997; Mulloli et al, 1998, Beeson et al, 1998, Pope et al, 2002; Hoek et al, 2002). Em estudo de revisão Vineis et al, (2004) analisaram diversos estudos de coorte nos Estados Unidos e na Europa. Baseados nos resultados destas coortes os autores concluem que a 
poluição do ar pode aumentar o risco de câncer de pulmão, especialmente quando combinada a outros fatores como tabagismo e exposição ocupacional.

Uma série de estudos foram conduzidos em ratos e camundongos expostos à níveis ambientais de emissões diesel. Animais foram expostos ao ar limpo ou 4 diluições de toda emissão baseados na concentração de material particulado $(30,100,300$ ou 1000 microg/m(3)). Machos e fêmeas de ratos F344 e camundongos $\mathrm{A} / \mathrm{J}$ foram expostos à inalação $6 \mathrm{~h} /$ dia, 7dias/semana, por 1 semana ou 6 meses. $O$ potencial carcinogênico foi avaliado pela contagem de micronúcleos e pela proliferação de adenomas nos camundongos $\mathrm{A} / \mathrm{J}$ com exposição de 6 meses. Os outros estudos paralelos demonstraram efeitos na função cardíaca e na resistência a infecção viral. Neste estudo, porém, os resultados apresentaram poucas e fracas associações com a exposição subcrônica. Não foram encontrados efeitos carcinogênicos (Reed et al, 2004).

Camundongos $\mathrm{A} / \mathrm{J}$ foram expostos em câmaras a 3 diferentes concentrações de fumaça de cigarro $(99,120,176 \mathrm{mg} / \mathrm{m} 3$ do total de material particulado em suspensão). Após um período de 4 meses em ar puro os animais foram sacrificados e as incidências de câncer de pulmão avaliadas. Os grupos expostos apresentaram incidências significativamente superiores às dos controles. Os dois grupos expostos às maiores concentrações apresentaram as maiores incidências, embora o grupo de maior concentração tenha apresentado incidência um pouco menor que o grupo intermediário (Witsch et al, 2004).

Recentemente o "stress" oxidativo tem sido o foco de investigações quanto à ser um dos mecanismos por trás do efeito genotóxico das partículas. Entretanto o papel do sistema de defesa antioxidante ainda precisa ser clareado, especialmente em relação as exposições a 
baixos níveis do poluente. Risom et al (2004) em seu estudo buscaram caracterizar os efeitos da exposição de curta duração em termos de dano ao DNA e da expressão de genes relativos ao "stress" oxidativo nos pulmões de camundongos. Camundongos foram expostos a inalação de $20 \mathrm{ou} 80 \mathrm{mg} / \mathrm{m} 3 \mathrm{em}$ dose única ou quatro doses menores (5 ou 20 $\mathrm{mg} / \mathrm{m} 3$ ) em 4 dias consecutivos. Os resultados mostraram que a expressão de HO-1 mRNA no tecido pulmonar estava elevada após os dois tipos de exposição. O nível de dano oxidativo do DNA em termos de 8-oxodG estava aumentado no tecido pulmonar após a exposição de dose única. O lavado bronqueoalveolar apresentou células com níveis aumentados de quebras do DNA. Os autores concluem que uma única dose alta gera 8oxodG nos tecidos, enquanto a mesma dose dividida em 4 exposições vai elevar o sistema de defesa antioxidante e proteger contra a geração de 8-oxodG.

Floret et al (2004) analisaram populações francesas vivendo próximo à incineradores. Em 1998 o Ministério Francês de Ambiente revelou que 15 dos 71 incineradores de resíduos sólidos municipais emitiam dioxinas em níveis próximos a $10 \mathrm{ng} / \mathrm{m} 3$, entre eles Besacon emitindo aproximadamente 16,3 fator de equivalência tóxica internacional/m3. Estes valores estavam muito acima do estipulado na Europa em $1994(0,1$ fator de equivalência tóxica internacional $/ \mathrm{m} 3$ ). Visando esclarecer a possível associação com as emissões aumentadas de dioxinas os autores dividiram a região em 4 zonas dependendo do nível de exposição de cada uma; casos e controles foram designados segundo o local de residência. Para cada caso de sarcoma foram escolhidos 10 controles. 27 casos de sarcoma foram encontrados entre 1980 e 1995, correspondendo a uma incidência de 2,44 por 100.000 habitantes. Comparados aos controles, o risco de desenvolver sarcoma não foi significantemente aumentado pelo local de exposição às dioxinas. 
Nos países industrializados o câncer de pulmão é a forma mais comum de neoplasia entre os homens e vem aumentando entre as mulheres. Para ambos os sexos as taxas refletem um comportamento de tabagismo. Contudo na Ásia, em especial na China os casos de neoplasia pulmonar em homens estão associados ao tabagismo, mas as taxas altas entre as mulheres não fumantes indicam haver outro fator de risco. Na África as taxas de câncer de pulmão são baixas, porém apresentam crescimento constante. Além do cigarro outras causas para câncer de pulmão tem sido questionadas, entre elas estão exposição ambiental ao tabaco, poluição interior pelo cozimento com óleo de cozinha, exposição ocupacional e poluição ambiental do ar. A predisposição genética associada a fatores carcinogênicos ambientais tem sido analisada. È esperada uma epidemia de câncer de pulmão na África e Ásia nos próximos anos (Lam et al, 2004).

Garshick et al (2004) fizeram um estudo de coorte retrospectiva. 54.973 trabalhadores expostos a emissão de diesel que morreram de câncer de pulmão entre 1959 e 1996 foram estudados. A mortalidade por câncer de pulmão em trabalhadore sexpostos foi elevada neste estudo. É pouco provável que a diferença possa ser explicada por fatores de confusão.

Objetivando examinar a associação entre incidência de câncer em Amsterdam e a intensidade do tráfego no local de residência, Visser et al (2004) cruzaram as informações da intensidade diária de tráfego no local de residência com dados do registro de câncer. Durante o período compreendido entre os anos 1989 e 1997 foram diagnosticados 27.157 casos de câncer na população de Amsterdam. Os resultados não permitem inferir uma associação entre residir em local de tráfego intenso e desenvolver neoplasias em adultos, 
uma exceção deve ser feita às doenças neoplásicas hematológicas em crianças, que demonstraram associação com residência próxima à vias de grande circulação.

O extrato de material orgânico de partículas em Shangai induziu transformação morfológica em células e apresentou um papel de iniciador na carcinogênese em camundongos. A análise dos extratos de diferentes distritos de Shangai mostrou não haver diferenças entre a atividade mutagênica relacionada ao local de coleta, com exceção da amostra proveniente da região central que apresentou atividade carcinogênica aumentada. A fração HPA foi a que esteve mais fortemente associada com a carcinogenicidade. Zhao et al (2003) concluíram que o material particulado urbano de Shangai, o qual demonstrou atividades genotóxicas e carcinogênicas no bio ensaio conduzido, pode ser o responsável, pelo aumento do número de casos de câncer de pulmão nos últimos anos.

Evidências experimentais sugerem que a exposição dos pais a HPAs pode aumentar o risco de câncer durante a infância. Foram comparados 1.218 casos de tumores cerebrais em crianças e comparados a 2.223 controles no período de 1976 à 1994 . A exposição ocupacional dos pais a HPAs foi estimada. O risco foi ajustado para a idade e o sexo das crianças. A exposição paterna à HPAs anterior à concepção tem forte associação com os tumores cerebrais em crianças. A exposição materna anterior à gestação ou durante o período gestacional não teve associação com tumores infantis (Cordier et al, 2004). Em seu estudo Perera et al (2004) encontraram suscetibilidade aumentada para danos ao DNA em fetos com exposição a HPAs.

A exposição às emissões de diesel são classificadas como provavelmente carcinogênica e as emissões de motores à gasolina são classificadas como possivelmente carcinogênicas. Guo et al (2004) seguiu uma coorte de nascidos na Finlândia entre 1906 e 
1945 durante o periodo de 1971 a 1995. As incidências dos casos de câncer de esôfago $(n=2.198)$, ovário $(n=5.082)$, testículo $(n=3.807)$, rim $(n=7.366)$, bexiga $(n=8.110)$ e leucemias $(n=4.562)$ foram identificados através do Registro de Câncer Finlandês. As ocupações foram utilizadas para estimar a exposição ao diesel ou gasolina. Os resultados indicam haver associação entre exposição ao diesel e câncer de ovário.

Ueng et al (2004) em seu estudo objetivou determinar a atividade endócrina das partículas emitidas por motocicletas usando células humanas de tumores mamários (MCF7) e fêmeas de rato tratados com o extrato orgânico de material particulado. O tratamento das camundongas com $10 \mathrm{mg} / \mathrm{kg}$ de peso de extrato orgânico de partículas através de injeção intraperitoneal não apresentou efeitos sobre o peso dos úteros das camundongas. Os resultados indicam que o extrato orgânico de material particulado é antiestrogênico in vitro $\mathrm{e}$ in vivo.

As incidências de neoplasias são diferentes nas regiões do Municipio de São Paulo e não existe uma correlação entre a renda média do distrito e os níveis de neoplasias o que levaria a uma explicação sócio-econômica para estas diferenças; contudo distritos historicamente mais industrializados apresentam taxas de câncer até quatro vezes maiores que de outras regiões do Município, a densidade industrial dos distritos correlaciona-se com as taxas de câncer. Foi encontrada boa correlação estatística entre poluição do ar e incidência de canceres, com destaque para o poluente ozônio e as neoplasias de laringe (Coeficiente $=0,9929 ; \mathrm{p}=0,007)$ e pele $($ Coeficiente $=0,9851 ; \mathrm{p}=0,015)$ no Município de São Paulo. (Cangerana-Pereira, 2000) 


\subsection{Objetivos:}

Os objetivos deste estudo podem ser apresentados como se segue:

- Testar a reprodutibilidade do efeito promotor de neoplasias pulmonares da poluição urbana em camundongos tratados com n-nitroso-metil uretana por via intraperitonial.

- Verificar se a poluição tem papel iniciador nas neoplasias.

- Verificar o possível papel promotor de carcinogênese pulmonar da poluição urbana.

- Determinar se o papel promotor acima referido é dependente da fração gasosa ou particulada da poluição atmosférica de São Paulo. 


\section{Material e Métodos:}

Este é um estudo experimental que utilizou 6 grupos de camundongos expostos a diferentes condições atmosféricas em câmaras de topo aberto, colocadas na Faculdade de Medicina da USP. Este local foi escolhido por apresentar níveis altos de poluentes, tornando-se adequado para a realização deste experimento. A existência de uma estação de monitoramento do ar da CETESB próximo ao local, possibilita o acompanhamento dos níveis dos poluentes.

150 Camundongos Suíços fềmeas com 4 semanas de idade foram divididos em 6 grupos: Grupo 1: camundongos em câmara com ar puro (câmara Limpa), sem carcinógeno. Grupo 2: camundongos em câmara com ar puro (câmara Limpa), com carcinógeno. Grupo 3: camundongos em câmara com filtro para gases (câmara Intermediária), sem carcinógeno. Grupo 4: camundongos em câmara com filtro para gases (câmara Intermediária), com carcinógeno. Grupo 5: camundongos em câmara sem filtros (câmara Suja), sem carcinógeno. Grupo 6: camundongos em câmara sem filtros (câmara Suja), com carcinógeno.

\subsection{Tamanho da amostra:}

Foram utilizados 150 camundongos suíços fêmeas com idade de 4 semanas. Foram escolhidos animais do sexo feminino por apresentarem maior sensibilidade. Foram utilizados camundongos suíços devido a maior variabilidade genética deste grupo de animais. 


\subsection{Metodologia:}

Em uma das câmaras acima descritas, denominada de AR LIMPO, o ar foi filtrado para partículas e para gases; a segunda câmara teve filtro para gases e foi denominada de AR INTERMEDIÁRIO ; na última câmara, denominada de AR SUJO, o ar não foi filtrado. $\mathrm{O}$ ar foi monitorado através das medições da CETESB. A eficiência dos filtros foi testada durante o experimento através de medições dos poluentes dentro e fora das câmaras.

Em cada câmara os camundongos foram divididos em dois grupos, um deles recebeu solução salina, e foi utilizado como controle, e o outro foi tratado com n-nitrosometil-uretana $(2 \mathrm{~g} / \mathrm{kg}$ de peso) em duas doses, que serviu para induzir a formação das neoplasias. Os camundongos foram acompanhados por 2 meses, tendo como base o experimento de Reymão et al. (1997). Ao final do experimento os camundongos foram sacrificados e foi feita autópsia. Os camundongos foram anestesiados via peritonial com $0,3 \mathrm{~g}$ de Thiopentax, tiopental sódico. Após o efeito da anestesia ser comprovado por pressão nas patas traseiras, os camundongos foram presos em cortiça e tiveram a aorta abdominal seccionada, morrendo por choque. Os órgãos foram tirados e pesados em separado.

Foram feitas pesagens do pulmão em conjunto com a traquéia. Os pulmões foram instilados com formol tamponado durante 24 horas. Este material foi submetido à verificação quanto a presença de tumores (lesões de cor castanho-claro) e sua contagem macroscópica. Foram feitos cortes dos pulmões e as lâminas foram coradas por Hematoxilina-Eosina. Foram feitas também lâminas de baços que apresentaram tamanhos alterados e de um ovário que estava aumentado. 


\subsection{Caracterização da exposição:}

Foram utilizadas as medições feitas pela unidade de monitoramento da CETESB e medições feitas pelo grupo através de medidas da massa de aerossol coletada em filtros de nitro-celulose (impactador Harvard para PM10) e dos gases oxidantes e dióxido de nitrogênio usando a tecnologia de amostragem manual preconizada no aparelho Trigás produzido pela empresa Energética (Rio de Janeiro).

Foram realizadas medidas de poluentes pela equipe do Laboratório de Poluição Atmosférica Experimental da Faculdade de Medicina da USP objetivando verificar e eficácia dos filtros. Os parâmetros medidos foram Black Carbon, PM2,5 $\mu$, e Dióxido de Nitrogênio (NO2).

Para a medição do Black Carbon foi utilizado um Amostrador de Pequenos Volumes- Energética, o material coletado em filtro foi analisado por Refletância da Luz (ABNT, 1989 ).

O Dióxido de Nitrogênio foi medido pela técnica do Arsenito de Sódio (Intersociet Commity, 1989) e coletado em Amostrador de pequenos volumes da Marca Energética.

O PM 2,5 $\mu$ foi coletado em Impactador Harvard e medido por refletância da luz.

\subsection{Análise estatística:}

Foi feita a análise descritiva de todas as variáveis do estudo. As variáveis foram apresentadas em termos de seus valores de tendência central e de dispersão. Para se comparar cada uma das variáveis entre os grupos foi utilizado o teste de Kruskal-Wallis. E a seguir o teste de comparações múltiplas de HSD-Tukey (Honest significant differences), para se saber em que grupos estavam as diferenças. Foi utilizado um teste não paramétrico 
(teste de Kruskal-Wallis), pois a amostra não apresentava homogeneidade das variâncias (Teste de Levene), e algumas não tinham distribuição normal (Teste de Kolmogorovsmirnov).

Para se comparar os pesos semana a semana foi utilizado o teste de análise de variância de medidas repetidas, uma vez que esta variável apresentava distribuição normal e homogeneidade das variâncias. Para comparar os grupos foi utilizado o teste HSD-Tukey, e para comparar os tempos foi utilizado o teste de comparações múltiplas de NewmanKeuls.

O nível de significância foi de 5\%. O pacote estatístico utilizado foi o SPSS 8.0 para windows.

\subsection{Questões éticas:}

Os camundongos foram mantidos em condições de higiene e espaço adequadas. Foram alimentados com 60 gr. de ração Nuvital- Nuvilab Cr1 e $140 \mathrm{ml}$ de água autoclavada por camundongo, por semana. Os procedimentos adotados não provocaram dor ou sofrimento aos animais. Existiu a necessidade da utilização de animais na realização deste experimento para comprovar ou não uma relação entre neoplasias e poluição do ar. A manipulação dos animais, de seus dejetos ou de outros materiais não representou risco para a saúde dos pesquisadores ou de terceiros, ou risco ambiental.

\subsection{Câmaras de Topo Aberto}

Foram utilizadas três câmaras de topo aberto, pertencentes ao Instituto de Botânica, nas quais é injetado ar pela parte inferior, durante a trajetória o ar entra em contato com os 
camundongos expostos colocados em gaiolas, a saída do ar se dá pela parte superior da câmara.

As câmaras são recobertas por um polietileno de baixa densidade aditivado contra a passagem de raios ultra -violeta. Na parte inferior este plástico possui dupla camada sendo a parte externa inteiriça e a parte interna perfurada possibilitando a passagem de ar para dentro da câmara. A entrada de ar proveniente do ambiente externo localiza-se entre estas duas camadas de polietileno.

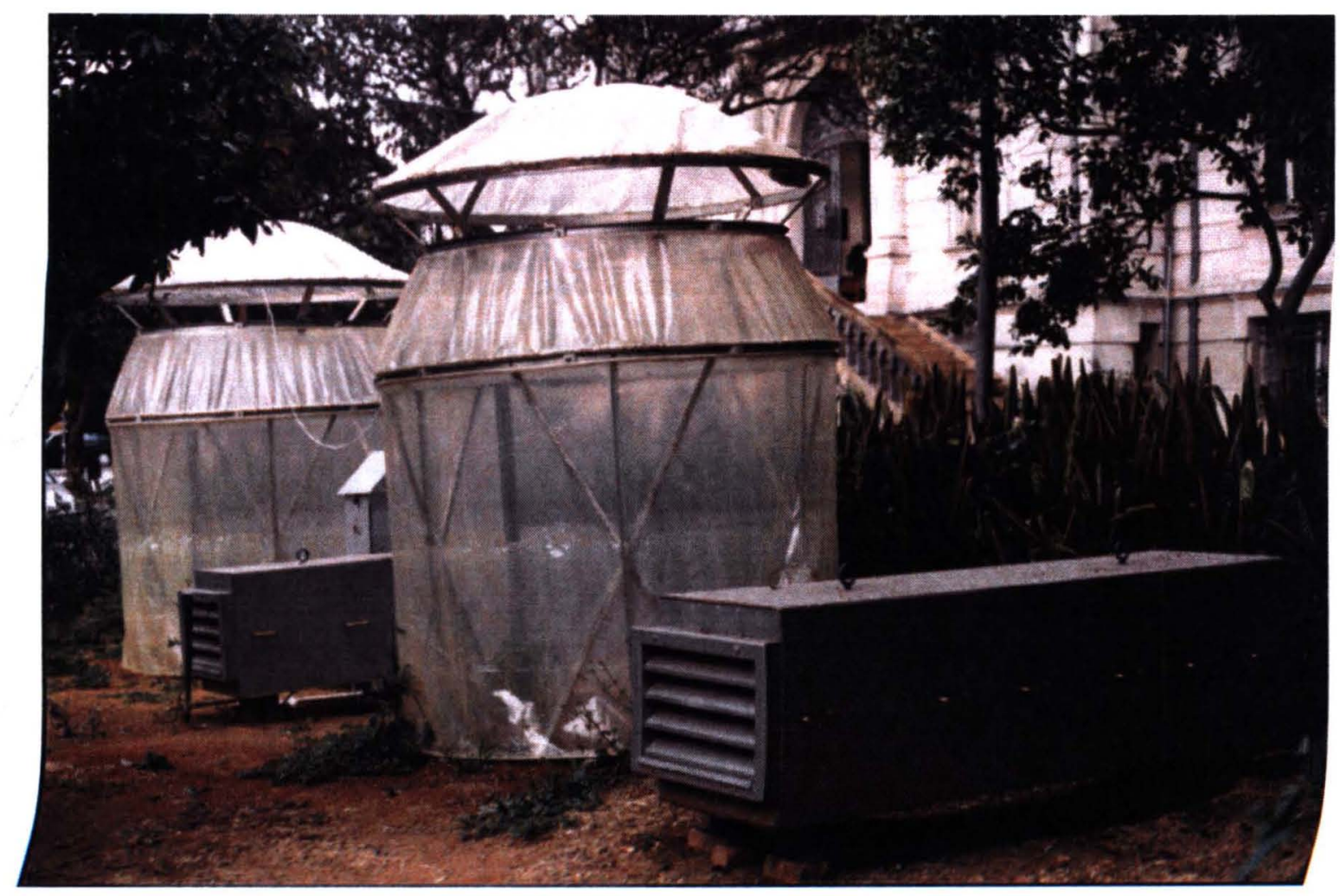

Fotografia 1: Câmaras de Topo Aberto.

A câmara denominada de "Limpa" neste estudo possui uma caixa na qual estão ondicionados os filtros. Para uma eficiente filtragem do ar exterior foi utilizado um njunto de filtros conforme a descrição à seguir:

-Filtro externo para material grosseiro; 
-Filtro tipo bolsa para partículas grandes;

-Filtros purafil e purakol de carvão ativado e permanganato de potássio para gases;

-Filtro para partículas;

-Filtro EPA para partículas menores que $2 \mu$.

A câmara intermediária possui caixa de filtros semelhante a da câmara limpa com os filtros descritos à seguir:

-Filtro para materiais grosseiros;

-Fitros de carvão ativado e permanganato de potássio para gases.

A câmara suja não teve nenhum tipo de filtragem.

$\mathrm{O}$ ar é levado para dentro das câmaras através de ventiladores colocados na entrada.

A fotografia 1 apresenta as câmaras de topo aberto. A fotografia 2 mostra a caixa de filtros.

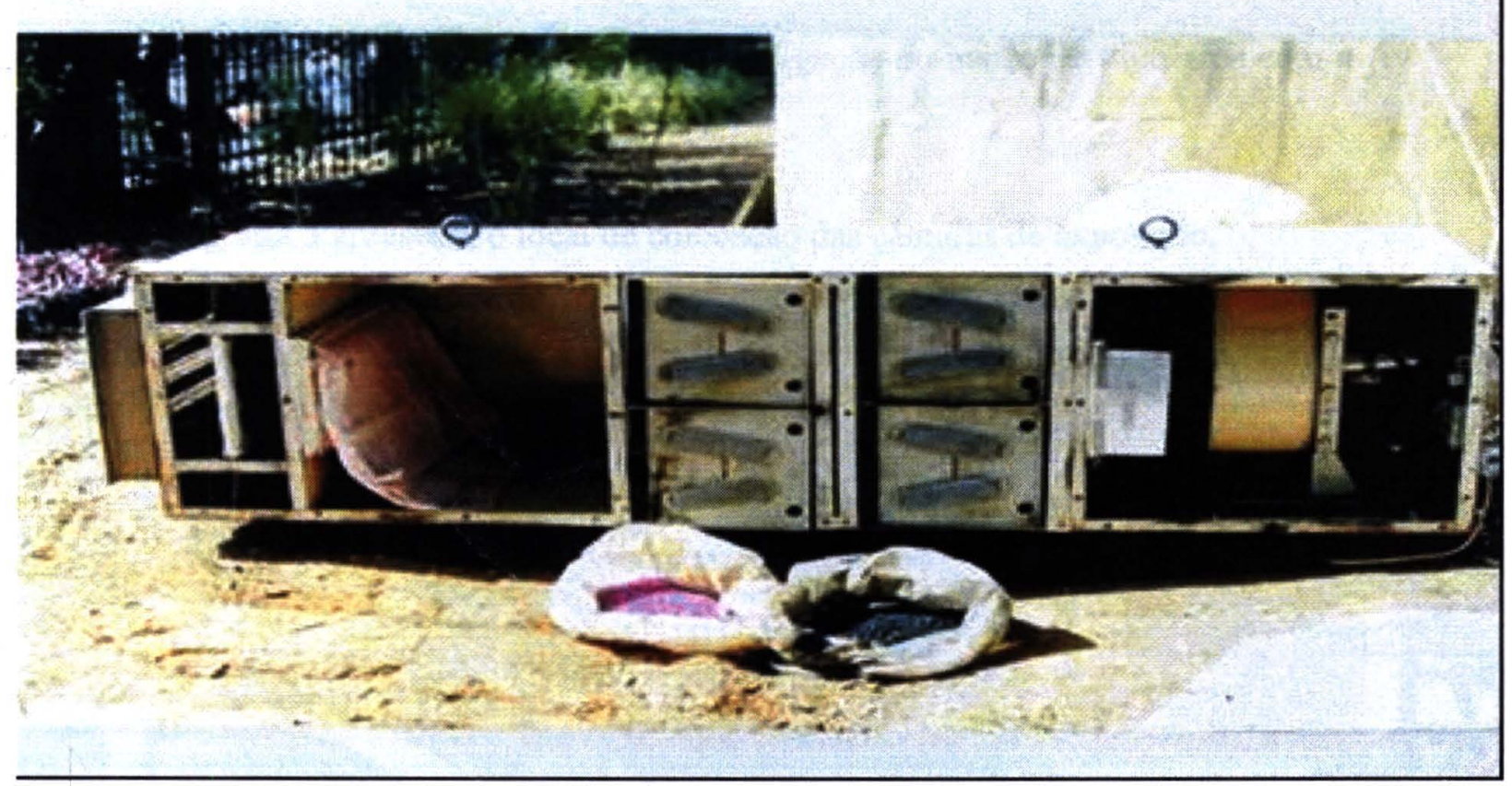

Fotografia2: Caixa com filtros para partículas e gases. 


\subsection{Local de Exposição:}

O Distrito de Pinheiros, onde se situa o bairro de Cerqueira César, é uma região poluída do Município de São Paulo. Existe neste local uma estação amostradora da CETESB que mede rotineiramente material particulado, Dióxido de Enxofre, Dióxido de Nitrogênio e Monósido de Carbono.

O Local da estação da CETESB e o local de colocação das câmaras de topo aberto estão distantes aproximadamente 100 metros. Na Av Dr. Arnaldo e na R. Teodoro Sampaio circulam uma grande quantidade de veículos, as câmaras foram colocadas próximo a esquina destas ruas dentro do jardim da Faculdade de Medicina da Universidade de São Paulo. A Av Dr. Arnaldo faz a ligação da zona oeste da cidade com a região central da Av Paulista, por esta razão, nos horários da manhã e final da tarde o trânsito se intensifica. A R. Teodoro Sampaio é uma rua comercial e faz a ligação do bairro de Pinheiros com a Av Dr. Arnaldo.

A fotografia 3 apresenta o local de colocação das câmaras de exposição.

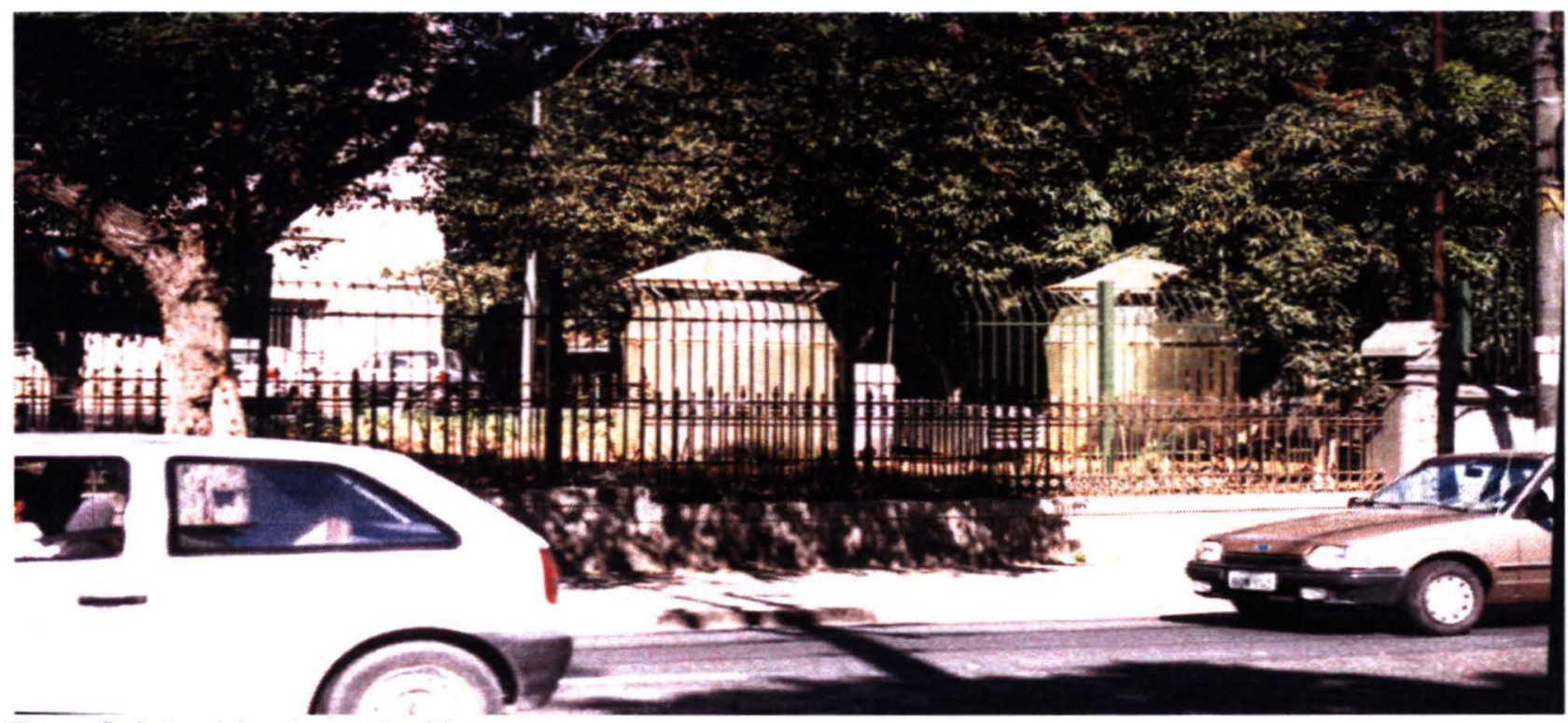

Fotografia 3: Local de colocação das Câmaras. 


\subsection{Uretana:}

Uretana é o éster etílico do ácido carbâmico, comumente chamado etiluretana ou, simplesmente uretana (Hoffman, 1968; Weintranb,1977). Foi o primeiro carcinógeno solúvel em água a ser descoberto. Apresenta-se sob a forma de cristais, de sabor salgado, exibe uma ação hipnótica e por esta razão foi usada por muitos anos como anestésico em humanos. O uso atual da uretana, baseado em sua atividade depressora do Sistema Nervoso Central, praticamente se restringe à produção de anestesia geral em animais de laboratório, por meio de injeção intravenosa ou intraperitoneal.

Acreditava-se que a ação carcinogênica da uretana estava restrita ao pulmão (Mirvish,1968). No entanto ficou demonstrado que a uretana não é um carcinógeno exclusivo do pulmão, ao ser observado que camundongos tratados desenvolviam tumores de pele após pincelagem com óleo de croton que agiria como promotor (Graffi et al, 1953). Atualmente acredita-se que a uretana seja um carcinógeno multipotente podendo produzir, além dos carcinomas pulmonares e dos papilomas de pele, linfomas do timo,carcinoma mamário, hepatoma e outros tipos de tumores em camundongos e outros animais. (Reymão, 1997)

A indução de tumores pela uretana foi relatada como particularmente efetiva quando doses repetidas da substância eram administradas por injeções ou na água de beber, e quando eram utilizados camundongos jovens.

Shimkin $(1955,1966)$ relata os primeiros trabalhos sobre tumorigênese de pulmão por uretana demonstrando que a uretana é ativada quando injetada ou administrada via oral e que a taxa de indução de tumores é proporcional à dose. Embora a maioria dos tumores sejam pequenos e não desenvolvam metástases, alguns podem evoluir para carcinoma. 
Os camundongos apresentam uma incidência relativamente alta de tumores espontâneos no pulmão, e tanto camundongos suíços com $\mathrm{BALB} / \mathrm{C}$ são sensíveis à tumorigênese de pulmão pela uretana. Uma dose de $1 \mathrm{~g} / \mathrm{Kg}$ de peso induz a formação de 3 adenomas após 4 semanas de tratamento. $\mathrm{O}$ câncer de pulmão humano surge, usualmente, no epitélio brônquico. Em camundongos e ratos os tumores induzidos por uretana surgem no epitélio alveolar. (Reymão et al, 1997)

A uretana induz neoplasias através de stress oxidativo, é classificada como carcinógeno animal não existindo evidências de sua ação em humanos. (IARC) 


\section{Resultados:}

\subsection{Medidas de poluição}

As medidas de poluição efetuadas pelo grupo do Laboratório de Poluição do Ar da Faculdade de Medicina da USP indicaram que os filtros utilizados nas Câmaras Limpa tiveram uma eficácia de $100 \%$ na filtragem de partículas e $54 \%$ na filtragem de gases. $\mathrm{Na}$ Câmara Intermediária os filtros tiveram eficácia de $54 \%$ na filtragem de gases. Nesta Câmara ao filtros químicos utilizados para reter os gases exerceram ação mecânica sobre as partículas retendo $52,22 \%$ das mesmas. A Câmara suja apresentou atmosfera igual a externa uma vez que seu ar não foi filtrado.

Os valores médios dos poluentes no periodo em estudo ( 09 de agosto à 13 de outubro) foram: $14,33 \mu \mathrm{g} / \mathrm{m} 3$ de dióxido de enxofre, $115,74 \mu \mathrm{g} / \mathrm{m} 3$ de dióxido de nitrogênio e 1,87 ppm de monóxido de carbono na estação amostradora Cerqueira César. O material particulado não foi medido nesta estação no periodo do estudo por esta razão utilizamos o dado da estação mais próxima (Pinheiros), a média deste poluente foi 61,2 $\mu \mathrm{g} / \mathrm{m} 3$. Estas informações foram calculadas à partir de dados dos Boletins Diários de Qualidade do Ar da CETESB.Os valores encontrados estão dentro dos padrões de qualidade do ar. 
3.2. Análise descritiva das variáveis do experimento:

Tabela 6: Análise descritiva das variáveis do experimento no Grupo Câmara Limpa Salina:

\begin{tabular}{cccccl}
\hline ANÁLISE & $\mathrm{N}$ & Mínimo & Máximo & Média & Desvio Padrão \\
DESCRITIVA & & & & & \\
\hline NÓDULOS & 25 & 0,00 & 0,00 & 0,00 & 0,00 \\
PESO_INÍCIAL & 25 & 24,50 & 30,80 & 28,10 & 1,47 \\
PESO_FINAL & 25 & 28,60 & 41,10 & 34,85 & 2,66 \\
DIFERENÇA & 25 & $-1,10$ & 11,90 & 6,75 & 2,82 \\
PULMÃO & 25 & 0,15 & 0,65 & 0,33 & 0,10 \\
RAÇÃO & 25 & 42,36 & 42,36 & 42,36 & 0,00 \\
ÁGUA & 25 & 58,63 & 58,63 & 58,63 & 0,00 \\
\hline
\end{tabular}

Tabela 7: Análise descritiva das variáveis do experimento no Grupo Câmara Limpa Uretana:

\begin{tabular}{|c|c|c|c|c|c|}
\hline $\begin{array}{c}\text { ANÁLISE } \\
\text { DESCRITIVA }\end{array}$ & $\mathrm{N}$ & Mínimo & Máximo & Média & Desvio Padrão \\
\hline NÓDULOS & 24 & 0,00 & 8,00 & 2,21 & 2,15 \\
\hline PESO_INÍCIAL & 24 & 22,00 & 29,40 & 25,90 & 1,90 \\
\hline PESO_FINAL & 24 & 29,08 & 40,11 & 34,29 & 2,51 \\
\hline DIFERENÇA & 24 & 3,03 & 13,08 & 8,39 & 2,78 \\
\hline PULMÃO & 24 & 0,25 & 0,43 & 0,33 & 0,04 \\
\hline RAÇÃO & 24 & 40,59 & 40,59 & 40,59 & 0,00 \\
\hline ÁGUA & 24 & 64,60 & 64,60 & 64,60 & 0,00 \\
\hline
\end{tabular}

Tabela 8: Análise descritiva das variáveis do experimento no Grupo Câmara Intermediária Salina:

\begin{tabular}{|c|c|c|c|c|c|}
\hline $\begin{array}{c}\text { ANÁLISE } \\
\text { DESCRITIVA }\end{array}$ & $\mathrm{N}$ & Mínimo & Máximo & Média & Desvio Padrão \\
\hline NÓDULOS & 23 & 0,00 & 0,00 & 0,00 & 0,00 \\
\hline PESO_INÍCIAL & 23 & 24,20 & 31,20 & 27,61 & 1,95 \\
\hline PESO_FINAL & 23 & 29,10 & 44,10 & 34,06 & 3,75 \\
\hline DIFERENÇCA & 23 & 1,20 & 17,40 & 6,45 & 4,34 \\
\hline PULMÃO & 23 & 0,26 & 0,44 & 0,35 & 0,04 \\
\hline RAÇÃO & 23 & 41,01 & 41,01 & 41,01 & 0,00 \\
\hline ÁGUA & 23 & 71,08 & 71,08 & 71,08 & 0,00 \\
\hline
\end{tabular}


Tabela 9: Análise descritiva das variáveis do experimento no Grupo Câmara Intermediária Uretana:

\begin{tabular}{cccccl}
\hline ANÁLISE & $\mathrm{N}$ & Mínimo & Máximo & Média & Desvio Padrão \\
DESCRITIVA & & & & & \\
\hline NÓDULOS & 21 & 0,00 & 9,00 & 3,33 & 2,69 \\
PESO_INÍCIAL & 23 & 21,80 & 28,10 & 25,36 & 1,52 \\
PESO_FINAL & 23 & 25,81 & 37,52 & 31,91 & 3,39 \\
DIFERENÇA & 23 & 0,40 & 13,10 & 6,55 & 4,04 \\
PULMÃO & 23 & 0,27 & 0,52 & 0,37 & 0,05 \\
RAÇÃO & 23 & 39,75 & 39,75 & 39,75 & 0,00 \\
ÁGUA & 23 & 69,40 & 69,40 & 69,40 & 0,00 \\
\hline
\end{tabular}

Tabela 10: Análise descritiva das variáveis do experimento no Grupo Câmara Suja Salina.

\begin{tabular}{cccccl}
\hline ANÁLISE & N & Mínimo & Máximo & Média & Desvio Padrão \\
DESCRITIVA & & & & & \\
\hline NÓDULOS & 25 & 0,00 & 0,00 & 0,00 & 0,00 \\
PESO_INÍCIAL & 25 & 24,50 & 31,80 & 28,31 & 1,67 \\
PESO_FINAL & 25 & 24,00 & 38,10 & 33,36 & 3,00 \\
DIFERENÇA & 25 & $-5,70$ & 10,30 & 5,05 & 3,52 \\
PULMÃO & 24 & 0,26 & 0,54 & 0,38 & 0,08 \\
RAÇÃO & 25 & 43,77 & 43,77 & 43,77 & 0,00 \\
ÁGUA & 25 & 67,25 & 67,25 & 67,25 & 0,00 \\
\hline
\end{tabular}

Tabela 11: Análise descritiva das variáveis do experimento no Grupo Câmara Suja Uretana.

\begin{tabular}{cccccl}
\hline $\begin{array}{c}\text { ANÁLISE } \\
\text { DESCRITIVA }\end{array}$ & $\mathrm{N}$ & Mínimo & Máximo & Média & Desvio Padrão \\
\hline NÓDULOS & 22 & 0,00 & 18,00 & 4,64 & 3,97 \\
PESO_INÍCIAL & 24 & 22,40 & 28,70 & 25,80 & 1,69 \\
PESO_FINAL & 24 & 26,59 & 39,61 & 34,60 & 2,61 \\
& & & & & \\
DIFERENÇA & 24 & $-1,71$ & 17,21 & 8,80 & 3,73 \\
& & & & & \\
PULMÃO & 24 & 0,27 & 0,53 & 0,35 & 0,05 \\
RAÇÃO & 24 & 45,66 & 45,66 & 45,66 & 0,00 \\
ÁGUA & 24 & 64,73 & 64,73 & 64,73 & 0,00 \\
\hline
\end{tabular}




\subsection{Número de Nódulos:}

Durante o experimento morreram 4 animais na câmara intermediária, 2 no grupo controle e 2 que haviam recebido uretana; 1 animal no grupo exposto (câmara suja) com carcinógeno morreu logo após a aplicação e 1 animal na câmara limpa no grupo com uretana. O resultado da contagem dos nódulos está apresentado na tabela abaixo, são apresentados apenas os resultados do grupo que recebeu uretana, pois nenhum animal do grupo que recebeu salina apresentou nódulos.

Tabela 12: Número de nódulos por animal que recebeu uretana por grupo de exposição. (1 ${ }^{\circ}$ PARTE)

ANIMAL

\begin{tabular}{llcc}
\hline 1 & 2 & 2 & 1 \\
2 & 4 & Não insuflou & 0 \\
3 & 0 & 7 & 7 \\
4 & 2 & 2 & 2 \\
5 & 1 & 5 & 1 \\
6 & 0 & Não insuflou & 2 \\
7 & 1 & 0 & 5 \\
8 & 3 & 6 & 3 \\
9 & 3 & 2 & Não insuflou \\
10 & 6 & 5 & 3 \\
11 & 8 & 1 & 5 \\
12 & 1 & 2 & 4 \\
13 & 3 & 9 & 8 \\
\hline
\end{tabular}


Tabela 12: Número de nódulos por animal que recebeu uretana por grupo de exposição. ( $2^{\circ}$ PARTE)

\begin{tabular}{cccc}
\hline 14 & 7 & 1 & 1 \\
15 & 2 & 3 & 5 \\
16 & 1 & 1 & 0 \\
17 & 0 & 9 & 5 \\
18 & 2 & 0 & 6 \\
19 & 2 & 3 & 5 \\
20 & 1 & 1 & 4 \\
21 & 0 & 3 & 8 \\
22 & 1 & 5 & 9 \\
23 & 2 & 3 & Não insuflou \\
24 & 1 & Não insuflou & 18 \\
\hline
\end{tabular}

Onde:CLU=Câmara Limpa Uretana

CIU=Câmara Intermediária Uretana

CSU=Câmara Suja Uretana

O estudo histológico das lâminas coradas por HE mostrou que os nódulos são adenomas. A fotografia 4 mostra um nódulo encontrado em camundongo do experimento. A lâmina deste adenoma esta apresentada na fotografia 5 .

Como é possível observar na análise descritiva das variáveis os grupos que foram tratados com solução salina não desenvolveram nódulos, quanto aos animais que receberam uretana a média do número de nódulos na Câmara Limpa foi 2,2; na Câmara Intermediária a média foi de 3,3 nódulos e na Câmara Suja a média foi 4,6 nódulos.

O gráfico abaixo representa os números de nódulos nos pulmões dos animais que receberam solução salina e uretana, por câmara de exposição. 
Gráfico 1: Número de nódulos nos pulmões dos camundongos segundo a câmara de exposição.

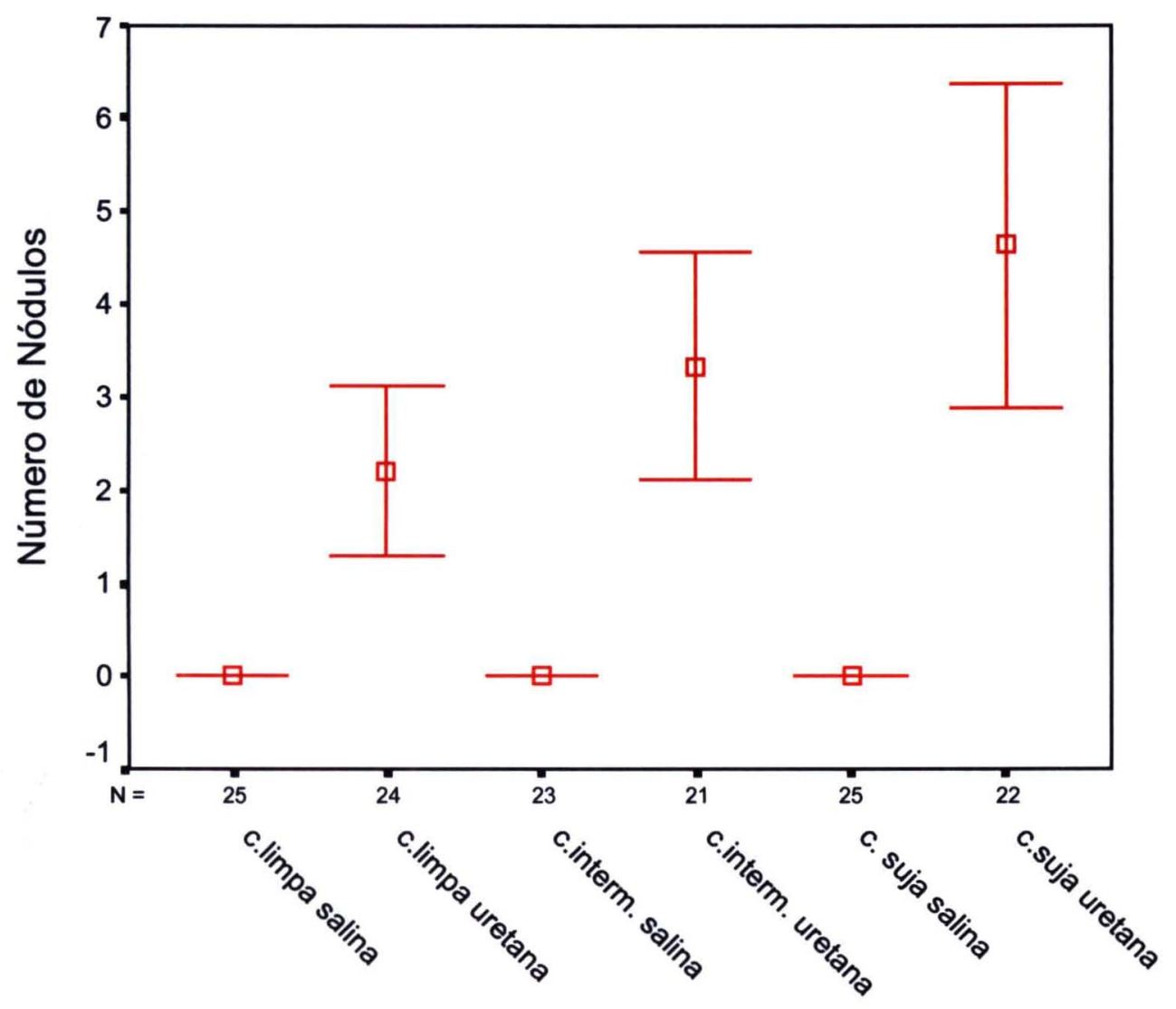




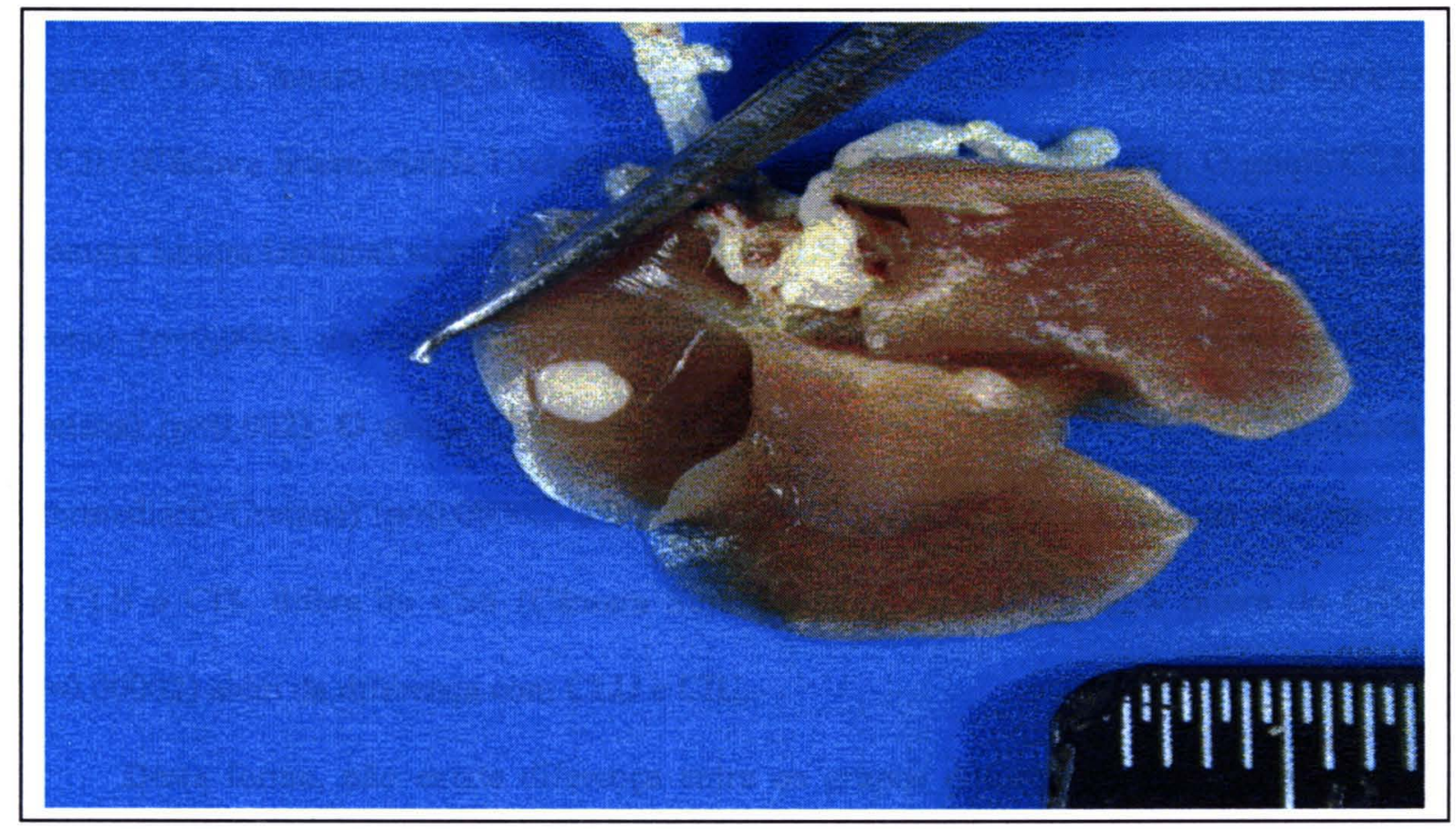

Fotografia 4 : Pulmão de camundongo com nódulo.

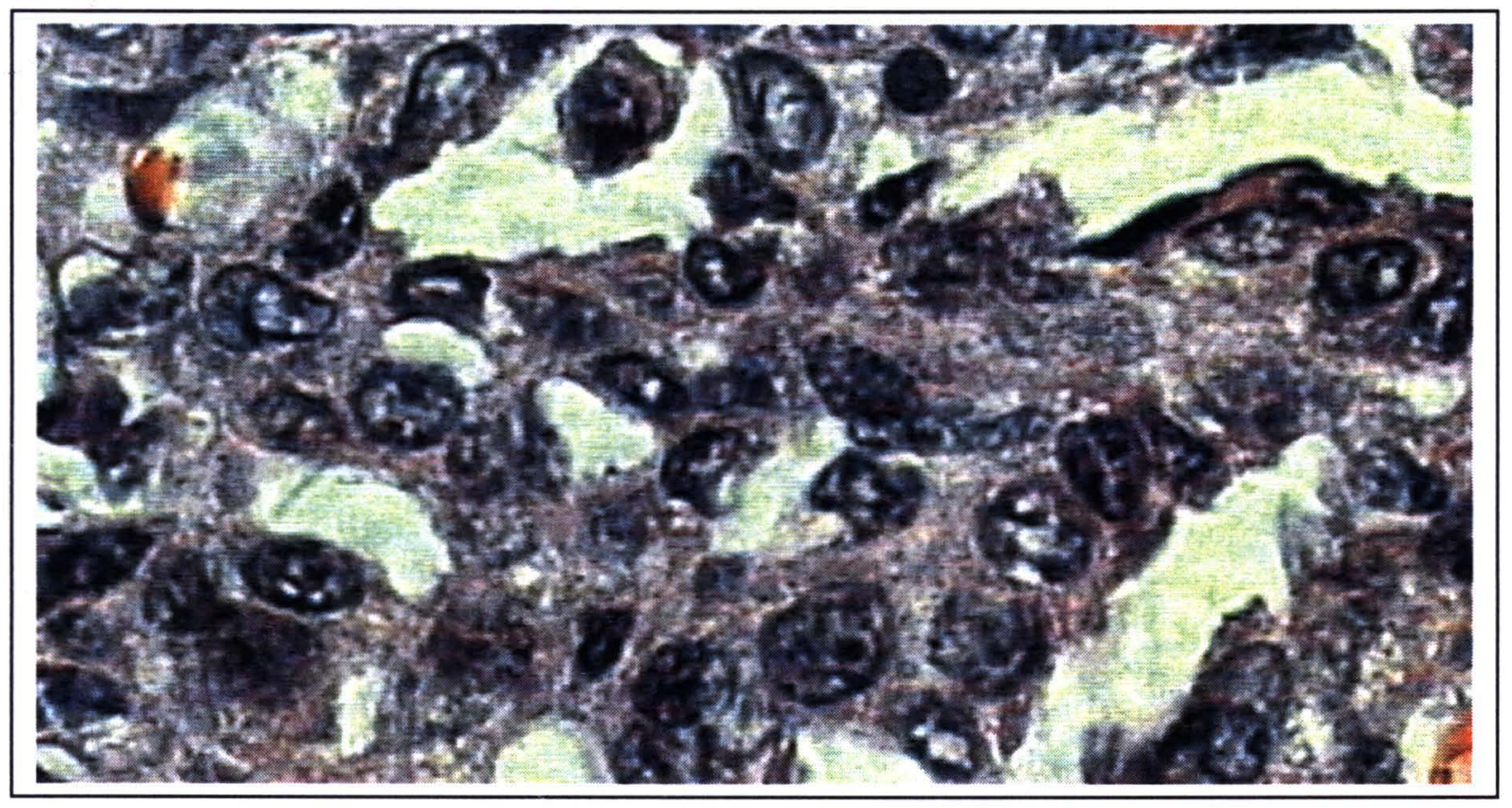

Fotografia 5: Adenoma Atípico (Coloração Hematoxilina Eosina) 
Há diferença entre os grupos na quantidade de nódulos pelo teste de Kruskal-Wallis: O grupo CLS (Câmara Limpa Salina) difere de CLU (Câmara Limpa Uretana) ( $p=0,003$ ), de CIU (Câmara Intermediária Uretana) $(\mathrm{p}=0,00002)$ e de CSU $(\mathrm{p}=0,00002) . \mathrm{O}$ grupo CLU (Câmara Limpa Uretana) além da diferença com CLS difere de CIS (Câmara Intermediária Salina) $(\mathrm{p}=0,004)$, da CSS (Câmara Suja Salina) $(\mathrm{p}=0,003)$ e de CSU (Câmara Suja Uretana) $(p=0,002)$. O grupo CIS além da diferença com CLU difere de CIU (Câmara Intermediária Uretana) $(\mathrm{p}=0,00002)$ e de $\operatorname{CSU}(\mathrm{p}=0,00002)$. $\mathrm{O}$ grupo $\mathrm{CIU}$, além de diferir de CLS e CIS, difere de CSS (Câmara Suja Salina) $(\mathrm{p}=0,00002)$. CSS difere de CSU $(\mathrm{p}=0,00002)$ além da diferença com CLU e CIU.

Desta forma, não existe diferença entre os grupos que receberam solução salina independentemente da Câmara de exposição. Quanto aos grupos que receberam uretana a difernça é significativa apenas entre o grupo da Câmara Limpa e o grupo da Cãmara Suja, não existindo diferenças com a Câmara Intermediária. 


\subsection{Peso dos Animais:}

O peso dos camundongos foi acompanhado durante este experimento. Os animais foram pesados semanalmente. Os gráficos 2 e 3 apresentam o peso semanal dos camundongos durante o experimento para o grupo que recebeu solução salina e para o grupo que recebeu uretana. É possível observar o ganho semanal para cada grupo.

Gráfico 2: Pesos dos animais ao longo do experimento, por semana, por grupo que recebeu solução salina.

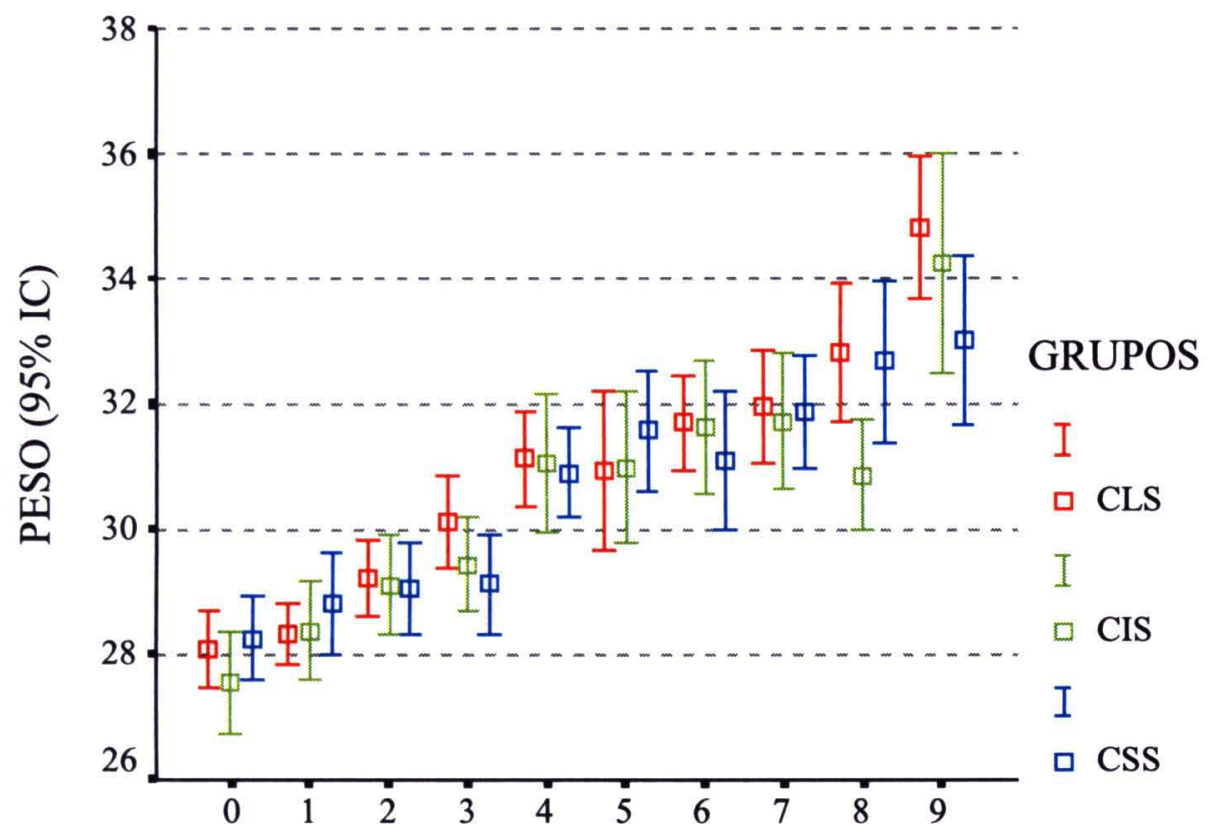

SEMANA

Onde:CLS= Câmara Limpa Salina

CIS = Câmara Intermediaria Salina

CSS $=$ Câmara Suja Salina 
Gráfico 3: Pesos dos animais ao longo do experimento, por semana, por grupo que recebeu uretana.

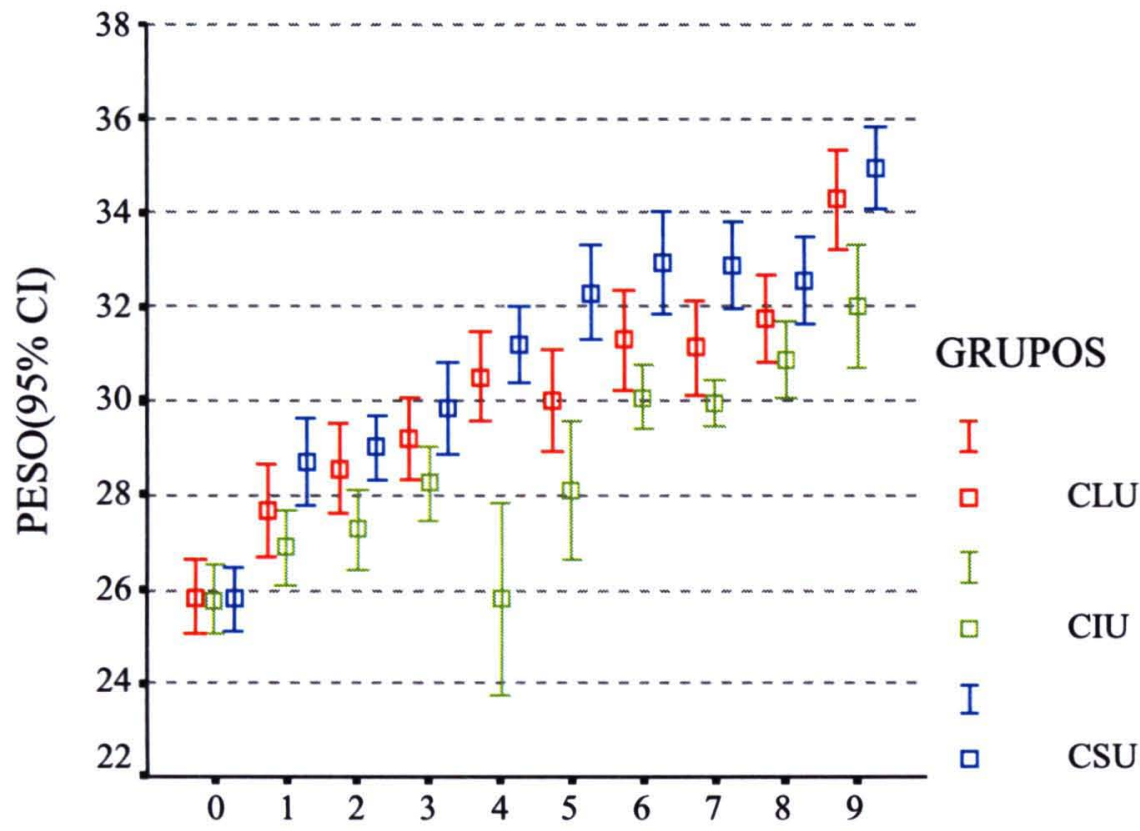

SEMANA

$$
\begin{gathered}
\text { Onde: } \mathrm{CLU}=\text { Câmara Limpa Uretana } \\
\text { CIU }=\text { Câmara Intermediária Uretana } \\
\text { CSU }=\text { Câmara Suja Uretana }
\end{gathered}
$$

A análise de variância para medidas repetidas mostrou que existiam diferenças entre os grupos $(\mathrm{p}<0,05)$ e entre os tempos $(\mathrm{p}<0,05)$.

Pelo teste de Comparações Múltiplas HSD- Tukey (Honest Significant Difference) pode-se observar que o grupo que ficou exposto na Câmara Intermediária e recebeu uretana (CIU) difere de todos os outros grupos quanto peso $(\mathrm{p}<0,0000)$. O grupo da Câmara Suja Uretana difere da Câmara Limpa Uretana $(p<0,01)$ e do grupo que ficou exposto na Câmara Intermediária Uretana $(\mathrm{p}<0,00002)$. 
É possível observar que os animais da câmara suja tiveram maior ganho de peso entre os grupos que receberam uretana $(p<0,00001)$.

Pelo teste de Comparações Múltiplas de Newman-Keuls, onde são comparados os tempos, podemos observar que as semanas $1,2,3,4,5$ são todas diferentes entre $s i(p<0,05)$. As semanas 6, 7, e 8 não apresentam diferenças. 


\subsection{Consumo de água e ração:}

O consumo de água e comida foi controlado durante a realização deste experimento.

A análise descritiva mostra que a média do consumo de água foi de $58,63 \mathrm{mls}$ na câmara limpa salina e de $69,40 \mathrm{mls}$ na câmara intermediária uretana. Para o consumo de água, pelo teste de Kruskal-Wallis, pode-se observar uma diferença significativa entre os grupos $(p<0,001)$. Pelo teste de comparações múltiplas de Tukey, pode-se observar que o grupo CLS difere do grupo CIU.

Através da análise descritiva das variáveis podemos observar que o consumo médio de ração na câmara intermediária salina foi de 41,01 gr de ração por animal, na câmara intermediária uretana o consumo foi de 39,75 gr., na câmara suja o grupo que recebeu solução salina consumiu 43,77 gr e o grupo que recebeu uretana 45,66 gr. Para consumo de ração, pelo teste de Kruskal-Wallis, pode-se observar uma diferença significativa entre os grupos $(p<0,001)$. Pelo teste de comparações múltiplas de Tukey, pode-se observar que o grupo CIS difere do grupo CSU, e o grupo CIU difere do grupo CSS.

Tabela 13: Média do consumo de água (mls) e ração (gramas) por grupo de camundongo por semana.

\begin{tabular}{ccc}
\hline GRUPO & RAÇÃO & ÁGUA \\
\hline CLS & 42,36 & 58,63 \\
CLU & 40,59 & 64,60 \\
CIS & 41,01 & 71,08 \\
CIU & 39,75 & 69,40 \\
CSS & 43,77 & 67,25 \\
CSU & 45,66 & 64,73 \\
\hline
\end{tabular}




\subsection{Observações no momento da Autópsia}

No momento do sacrificio não houve alterações detectáveis nos camundongos que receberam solução salina, não importando a câmara em que estiveram expostos. Entre os camundongos do experimento que receberam carcinógeno $(2 \mathrm{~g} / \mathrm{Kg})$ houve algumas alterações. Entre os animais exposto ao ar filtrado para gases e partículas (câmara limpa) um animal apresentou carcinoma de ovário, não houve outras alterações neste grupo. $\mathrm{Na}$ câmara intermediária dois camundongos apresentaram esplenomegalia (pesos dos baços de $0,375 \mathrm{~g}$ e $0,552 \mathrm{~g})$. Os animais que respiraram ar ambiente poluído apresentaram esplenomegalia - fotografia 6-com maior freqüência ( 3 animais) a alteração também foi mais severa com pesos de $0,976 \mathrm{~g} ; 0,932 \mathrm{~g}$ e $0,535 \mathrm{~g}$. Os baços aumentados apresentaram celularidade normal nas lâminas. Quatro camundongos da câmara suja apresentaram aderência dos intestinos ao peritônio; um camundongo tinha peritonite, megacólon e hepatoesplenomegalia.

Os camundongos que receberam ar poluido, independentemente de terem recebido carcinógeno, apresentaram uma tendência de úteros aumentados. 


$$
02
$$




\section{Discussão:}

A poluição no Município de São Paulo é bastante diferente de distrito para distrito dependendo do tipo de atividade econômica desenvolvida na região e principalmente da quantidade de veículos que circulam na mesma. Da mesma maneira as incidências de neoplasia não são homogêneas no Município de São Paulo (Cangerana-Pereira, 2000).

Efeitos mutagênicos da poluição tem sido descritos por diversos autores de nosso grupo (Guimarães et al, 2004; Soares et al, 2003; Ferreira et al, 2000) assim como pela literatura internacional (Belowska et al, 2004; Rivedal et al, 2003; Jadczyk, 2001; Grosovsky, 1999).

Muitos estudos associaram poluição do ar ao aumento do número de casos de neoplasias pulmonares, assim como em outras topografias. A poluição também está associada ao aumento de todos os casos de câncer. (Vineis et al, 2004; Garshik et al, 2004; Pope, 2002).

Estudos conduzidos no Município de São Paulo demonstraram que a poluição do ar desta cidade está associada com a incidência de neoplasias (Cangerana Pereira, 2000) e que as substâncias que compõe esta poluição são promotoras e progressoras de tumores pulmonares em camundongos (Cury et al, 2000; Reymão et al, 1997).

Objetivando classificar e quantificar os poluentes em São Paulo diferentes pesquisadores encontraram substâncias classificadas como prováveis e possíveis carcinógenos na atmosfera da cidade (Colón et al, 2001; Assunção \& Pesquero, 1999). Os HPAs são o maior grupo de poluentes genotóxicos orgânicos originados à partir do processo de combustão e armazenamento de combustíveis fósseis segundo Hemminki et al 
(1999). Não existem dados sobre este poluente no Município de São Paulo, contudo é possível estimar através dos demais poluentes atmosféricos que esta classe de poluente esteja presente em nossa atmosfera.

A poluição do ar ambiente tem, portanto, sido associada a eventos mutagênicos e carcinogênicos no mundo e especificamente na cidade de São Paulo. Cangerana-Pereira (2000) encontrou forte associação entre incidência aumentada de neoplasias respiratórias e o poluente ozônio, com destaque para a associação com o câncer de laringe, em estudo ecológico.

Embora a poluição como um todo tenha papel relevante no desenvolvimento de neoplasias a fração partículada tem sido apontada como responsável por estes eventos adversos à saúde (Vineis et al, 2004).

Em estudos conduzidos no município de São Paulo com modelos experimentais vegetais ficou comprovado que o material particulado de São Paulo tem atividade mutagênica (Guimarães et al, 2004; Batalha et al, 1999). Material particulado também está associado à resposta inflamatória. Dagher et al (2005) expuseram células de epitélio pulmonar humano (L132) ao material particulado 2,5 da cidade francesa de Dunkerke, os resultados indicaram um aumento na expressão gênica de citocinas de inflamação.

Muitos carcinógenos, incluindo HPAs, adsorvem nas partículas e podem ser depositados no trato respiratório, desta forma substâncias encontradas na forma gasosa podem estar presentes também na fração partículada da poluição atmosférica. As características da toxicidade do material partículado não estão completamente compreendidas. Como relatado na introdução desta tese a contribuição relativa do tipo de partícula, superficie e composição química não foram determinadas. Vale ressaltar que 
estas características são importantes pois partículas de diâmetro menor terão maior superficie, possibilitando a adsorção de mais substâncias tóxicas. Uma grande superficie significa grandes exposições a agentes carcinogênicos. (Vineis et al, 2004)

Muitas outras substâncias potencialmente carcinógenas estão presentes na poluição atmosférica. Embora suas concentrações sejam pequenas a exposição à poluição do ar é, na maioria das vezes, de longa duração. Pessoas que habitam grandes cidades estão permanentemente em contato com este tipo de substância tóxica. $\mathrm{O}$ monitoramento de cada um destes poluentes não é possível na atualidade. Entre as substâncias que podem estar presentes na atmosfera de um grande centro urbano muitas são reconhecidamente carcinógenas.

Entre estes poluentes figura o benzeno que é carcinogênico humano confirmado. Entre os HPAs estão classificados como carcinogênico humano suspeito: Benzo[a]antraceno, Benzo[a]pireno e dibenzo[ah]antraceno; e como carcinogênico animal: criseno. Como provável carcinogênico humano estão classificados o Benzo[a]antraceno, Benzo[a]pireno e o dibenzo[ah]antraceno; dienzo[ah]antraceno, indeno[1,2,3 cd] pireno são possíveis carcinogênicos humanos. Entre as dioxinas e furanos algunas compostos destacam-se quanto à toxicidade, sendo as que apresentam substituições nas posições de número 2, 3, 7 e 8; a 2,3,7,8-tetraclorodibenzo-p-dioxina é de maior interesse do ponto de vista toxicológico. As TCDDs estão classificadas como carcinogênico humano confirmado. Os furanos estão listados entre os possíveis carcinogênicos humanos. $O$ formaldeído é um carcinogênico humano suspeito, o Acetaldeído é carcinogênico animal.(ACGIH, 2001; WHO/LARC, 2002) 
Além das substâncias responsáveis diretamente pelo processo de carcinogênese que podem estar presentes no ar atmosférico, outras substâncias podem atuar de forma indireta. Segundo Chen et al (2005) o processo inflamatório tem papel crítico na progressão do câncer uma vez que a interação entre células tumorais pulmonares e macrófagos pode promover a invasão de outros tecidos.

$\mathrm{O} \mathrm{NO}_{2}$ inalado atinge porções periféricas do pulmão devido à sua baixa solubilidade. É um agente capaz de promover a oxidação de substratos orgânicos, como visto anteriormente. (EVANS et al ,1973). Barck et al (2005) concluíram que a exposição ao $\mathrm{NO}_{2}$ à níveis ambientais aumenta a atividade eosinofilica e que este pode ser um mecanismo através do qual poluentes do ar amplificam a reação inflamatória nas vias respiratórias.

Sixton et al (2004) expuseram células A549 (epitélio humano) à duas condições atmosféricas específicas objetivando avaliar resposta inflamatória destas células. Em uma câmara existia NO2 mais hidrocarbonetos, na outra câmara foi colocado O3. Os resultados demonstraram que as células expostas diretamente ao $\mathrm{O} 3$ tiveram uma resposta 2 à 3 vezes maior que o grupo que ficou exposto à NO2 e hidrocarbonetos. Efeitos infamatórios do $\mathrm{O} 3$ foram descritos também por Kley (1999) em estudo de revisão.

Estudos anteriores de nosso grupo (Reymão, 1997) demonstraram que a poluição é um promotor de neoplasias, que existe uma sugestão de efeito indutor e que a poluição acelera a progressão de adenomas e carcinomas. Estudos realizados através de bioensaio demostraram o potencial mutagênico da fração particulada da poluição (Ferreira et.al., 2000). 
Como visto na pequena descrição dos potenciais agentes carcinógenos presentes no ar das grandes cidades, existem diversas substâncias capazes de explicar a associação entre poluição atmosférica e neoplasias.

Tendo em vista a correlação entre alguns poluentes e incidência aumentada de neoplasias já documentada (Cangerana-Pereira,2000), considerando-se o potencial carcinogênico de muitos poluentes, e que outros poluentes embora não tenham este potencial podem contribuir de maneira indireta na progressão deste processo; fez-se necessária a correta avaliação dos efeitos da poluição do ar quanto a formação de neoplasias.

Em nosso estudo experimental pudemos reproduzir o modelo proposto por Reymão et al (1997) de maneira satisfatória reduzindo a quantidade de carcinógeno em 1/3 (de $3 \mathrm{~g} / \mathrm{kg}$ de peso para $2 \mathrm{~g} / \mathrm{kg}$ ).

Neste estudo pudemos controlar as variáveis que poderiam ter interferência no processo, tendo todas as condições controladas da alimentação aos fatores de exposição, assim como o agente indutor e seu controle. Desta forma esta tese experimental tem também um papel epidemiológico, uma vez que foi realizado um estudo intervencionista com animais que foram alocados randomicamente em diversos grupos. Para que o câncer, que é uma doença de latência longa, pudesse ser observado quanto à gênese e fatores promotores este estudo prospectivo foi realizado com animais de vida mais curta.

Os resultados do experimento mostraram haver diferença significativa entre os grupos de exposição. Nenhum animal que recebeu solução salina apresentou lesões. Dentre os animais que tiveram o processo induzido pelo stress oxidativo causado pela uretana, o grupo exposto na câmara suja apresentou o maior número de nódulos. 
Baseados nos resultados supracitados podemos inferir que este experimento permitiu observar claramente efeitos promotores da poluição do ar na carcinogênese. Tal efeito é muito provavelmente devido às características dos poluentes citadas anteriormente neste capítulo.

Neste experimento não houve comprovação de efeitos iniciadores de neoplasias relacionados aos poluentes uma vez que os animais que receberam solução salina não desenvolveram qualquer tipo de lesão pulmonar independentemente da exposição à poluição total ou parcial. Este resultado precisa ser analisado com ressalvas pois o nosso tempo de estudo ( 2 meses) é relativamente curto para que os agentes presentes na poluição do ar posam agir no organismo dos camundongos. Além de termos adotado um experimento de curta duração, no período em que os animais estiveram expostos as concentrações dos poluentes atmosféricos estiveram dentro do padrão de qualidade do ar. Em estudos de maior período de exposição, em que os animais ficaram expostos durante seis meses, também não foram encontrados efeitos iniciadores. (Reymão et al, 1997) Reed et al (2004) conduziram uma série de ensaios em que camundongos e ratos foram expostos a diferentes concentrações de exaustão de óleo diesel. O potencial carcinogênico deste produto foi estudado através da contagem de micronúcleos e proliferação de adenomas. Após seis meses de exposição não foram encontradas alterações significativas nos animais expostos a níveis de poluição subcrônicos. No experimento de Reed os camundongos não foram tratados com nenhum tipo de substância iniciadora para neoplasias. Existe a necessidade de que outros experimentos, objetivando analisar este potencial efeito indutor, sejam realizados para melhor esclarecer esta questão. 
Os dados de poluição demonstraram que os poluente estiveram dentro dos padrões de qualidade do ar. Estes resultados demonstram que o papel promotor de neoplasias da poluição do ar existe mesmo dentro dos limites estabelecidos, ou seja, uma vez que exista a ativação do processo por uma substância iniciadora a poluição é capaz de promover a formação do tumor mesmo apresentando concentrações dentro do padrão. Outros autores já encontraram efeitos adversos da poluição dentro dos padrões de qualidade do ar, entre eles Bakonyi et al (2004). Analisando o fato de que a poluição atmosférica, mesmo dentro do padrão de qualidade, pode promover neoplasias pulmonares em camundongos previamente expostos à substância indutora podemos questionar se humanos expostos à um indutor (como o hábito de fumar) também teriam a carcinogênese promovida pelo ar ambiente poluído. Desta forma, fumantes residentes em locais poluídos poderiam apresentar incidências aumentadas de câncer de pulmão. Estudos epidemiológicos podem ser conduzidos visando elucidar este efeito da poluição.

Os filtros para material particulado apresentaram boa eficácia filtrando $100 \%$ das particulas.

A filtragem de gases nas câmaras não apresentou a eficácia desejada. Com a filtragem de $54 \%$ de gases a câmara intermediária não foi um bom parâmetro para avaliar exposição ao material particulado, além da filtragem ineficiente de gases, estes filtros químicos tiveram uma ação mecânica retendo $52,22 \%$ das partículas. Com os resultados da filtração das câmaras podemos deduzir que neste experimento:

A Câmara Limpa não foi completamente limpa pois $46 \%$ dos gases estiveram presentes nesta câmara durante o experimento, entretanto a concentração de poluição nesta câmara esteve muito abaixo da concentração ambiental dos poluentes. 
A filtragem na Câmara Intermediária não permitiu observar efeitos do material particulado em separado. Nesta câmara $46 \%$ dos gases e $47,88 \%$ das partículas estiveram presentes durante o experimento. Podemos supor que a composição deste material particulado difere da composição ambiental deste poluente. Muito possivelmente o carvão ativado e o permanganato de potássio dos filtros químicos devem produzir partículas que são levadas para o interior da câmara de exposição, além de reterem o material particulado proveniente do ambiente externo. Esta câmara funcionou como um estágio intermediário entre a condição quase totalmente filtrada da Câmara Limpa e a ausência de filtros da Câmara Suja.

A poluição na Câmara Suja ficou dentro do esperado pois não foram utilizados filtros e portanto esta Câmara reproduz a condição externa.

Não foi possível atingir nosso objetivo de determinar se os efeitos carcinogênicos são dependentes de uma das frações da poluição. Esta observação foi prejudicada, especialmente, pela filtragem da câmara intermediária.

Com a filtragem das câmaras acima explanada, trabalhamos neste experimento com um gradiente de poluição do menos poluído ( câmara limpa) ao mais poluído (condição sem filtragem-ar ambiente). Nossos resultados apresentam coerência com esta informação pois o número de nódulos aumentou na câmara em que as concentrações de poluição foram maiores. Embora não fizesse parte de nossos objetivos, este gradiente de poluição permitiu uma associação com a contagem de nódulos, sugerindo um efeito de dose-resposta.

Através da observação dos animais no momento da autópsia foi possível perceber diferenças entre os grupos quanto ao peso do baço. Os animais que ficaram expostos na Câmara limpa não desenvolveram qualquer anomalia deste órgão, entretanto três animais 
que tomaram uretana e ficaram expostos na câmara sem filtragem apresentaram aumentos significativos do baço. Estas diferenças podem estar associadas a uma maior sensibilidade à uretana associada a efeitos imunológicos da poluição descritos anteriormente por outros autores (Yang et al, 2003; Drela et al, 2002).

O aumento do tamanho dos úteros dos animais expostos na Câmara Suja pode estar relacionada a ação hormonal de alguns poluentes no endométrio. (Ueng et al, 2004; Wolf, 1997).

O tumor de ovário encontrado em um animal que recebeu ar limpo deve estar relacionado a um efeito da uretana, uma vez que esta substância pode atuar como carcinógeno em diferentes topografias (Tannenbaum et al, 1958; Vol'fson, 1976).

Baseados nos dados de nosso experimento não podemos apontar as causas para o ganho de peso maior entre os animais da câmara suja que receberam carcinógeno, entretanto acreditamos ser importante o registro de tal achado. 


\section{Conclusões:}

O modelo experimental proposto por Reymão (1997) foi reproduzido de forma mais controlada neste experimento.

À partir dos resultados encontrados podemos concluir que a poluição do ar com a composição e as concentrações dos poluentes dos meses de agosto, setembro e outubro do ano de 2004 promoveu a formação de adenomas em camundongos previamente injetados com uretana.

Concluímos que a poluição não apresentou efeito iniciador do processo de carcinogênese neste experimento.

A observação do efeito que cada fração exerce sobre o processo de carcinogênese ficou prejudicada neste experimento devido à filtragem ineficiente das Câmaras, em especial da Câmara Intermediária.

Com base neste estudo observamos haver necessidade de aprimoramento da filtragem de poluentes das câmaras de topo aberto visando atingir resultados mais precisos. 


\section{Referências:}

1. Associação Brasileira de Gás Natural Veicular. Gás Natural Veicular- Institucional. Available from < URL: http://abgnv.org.br > [2004, august 18,19,20]

2. Associação Brasileira de Gás Natural Veicular. Gás Natural Veicular, 2004.

3. Associação Brasileira de Normas Técnicas, NBR-107-3-1/2, set. 1989.

4. AMERICAN CONFERENCE OF GOVERMMENTAL INDUSTRIAL HYGIENISTS. Limites de exposição (TLVS) para substâncias químicas e agentes fisicos e Indices biológicos de exposição (BEIs). Cincinatti: ACGIH, 2001. (Edição em português da ABHO - Associação Brasileira de Higienistas Ocupacionais, Campinas - SP)

5. ASSUNÇÃO, J.V. de; PESQUERO, C.R Carvalho, LRF. Levels of Dioxins and Furans in the atmosphere of the city of Sao Paulo, Brazil. Atmospheric Environment, sd. (in preparation)

6. ASSUNÇÃO, J.V. de; PESQUERO, C.R. Dioxinas e furanos - origens e riscos. Rev Saúde Pública 33(5) 523-30, 1999.

7. ASSUNÇÃO,J.V. de. Poluição Atmosférica. In: CASTELlanO, E. (ed.). Desenvolvimento Sustentado: Problemas e Estratégias. São Paulo: Academia de Ciências do Estado de São Paulo, 271-308, 1998.

8. BAKONYI,S.M.; DANNI-OLIVEIRA,I.M.; MARINS,L.C.; BRAGA,A.L. Air Pollution and Respiratory Diseases Among Children in the City of Curitiba, Brazil. Rev Saude Publica 38(5): 695-700, 2004.

9. BARCK,C.; LUNDAHL,J.; HALLDEN,G.; BYUN,G. Brief Exposures to NO2 augment the allergic inflammation in asthmatics. Environ Res. 97(1): 58-66, 2005.

10. BATALHA,J.R.F.; GUIMARÃES,E.T.; LOBO,D.J.A.; LICHTENFELS,A.J.F.C.; DEUR,T.; CARVALHO,H.A.; et al. Exploring the clastogenic effects of air pollutants in São Paulo (Brazil) using the Tradescantia micronuclei assay. Mutation research, 426, 229-32,1999. 
11. BEESON,W.L.; ABBEY, D.E.; KNUTSEN, S.F. Long term concentrations of ambient air pollutants and incident lung cancer in California adults: results of the AHSMOG study. Adventist Health Study on Smog. Environ. Health. Perspect. 106(12), 813-23, 1998.

12. BELOWSKA,J.; FRACZEK,A.; RAL, M.; SCHMAGER,J.; SKLADZIEN,J.; STREK,P.; SCIOG,M.; TRYBALA,D. Preliminary Study on the Frequency of Micronuclei in Buccal Mucosa Cells Sampled from Patients with Tumor of Larynx. (abstract) 61(4): 248-50, 2004.

13. BERGEL,G.; OVREBOL,S.; BOTNEN,V.; HEWER,A.; PHILLIPS, D.H.; HAUGEN,A.; MOLLERUP,S. Resveratrol Inhibits Benzo[a]pyrene DNA Adduct Formation in Human Bronchial Epithelial Cells. British Journal of Cancer 91: 333-338, 2004.

14. BERGEL,G.; OVREBOL,S.; EILERTSENL,E.; HAUGEN,A.; MOLLERUP,S. Analysis of Resveratrol as a Lung Cancer Chemopreventive Agent in A/J Mice exposed to Benzo[a]pyrene. British Journal of Cancer 91: 1380-3, 2004.

15. BERNSTEIN,J.A.; ALEXIS,N.; BARNES,C.; BERNSTEIN,I.L.; BERNSTEINJ.A.; NEL,A.; PEDEN,D.; DIAZ-SANCHEZ,D.; TARLO,S.M.; WILLIAMS,P.B. Health Effects of Air Pollution. J Allergy Clin Immunol 114(5): 1116-23, 2004.

16. BERQUÓ, ES; SOUZA, JMP; GOTLIEB, SLD. Bioestatística São Paulo: EPU, 1981.

17. BISHOP, J.M. The molecular genetics of cancer. Science 235:308-311, 1987.

18. BOFFETTA,P. Epidemiology of Environmental and Occupational Cancer.Oncogene 23(38): 6392-403, 2004.

19. BORM PJ, SCHINS RP, ALBRECHT C. Inhaled particles and lung cancer, part B: paradigms and risk assessment. Int J Cancer. 20;110(1):3-14, 2004

20. BRASIL. Lei Federal 8723 de 28 de Outubro de 1993 (Com correção no Diário Oficial de União de 29 de Outubro de 1993).

21. BRASIL. Resoluções CONAMA 18/1986; 03/1990; 07/1993; 18/1995; 227/1997. 
22. BRASIL. Portaria Normativa IBAMA 348/1990.

23. CANGERANA-PEREIRA,F.A. Estudo exploratório da influência da poluição do ar na incidência de câncer por distrito do Município de São Paulo. São Paulo, 2000 [Dissertação de Mestrado - Faculdade de Saúde Pública, USP].

24. CHEN,J.J.; LIN,Y.C.; YAO,P.L.; YUAN,A.; CHEN,H.Y.; SHUN,C.T.; TSAI,M.F.; CHEN,C.H.; YANG,P.C. Tumor Associated Macrophages: the Double Edged Sword in Cancer Progression. J. Clin. Oncol. 23(5): 953-64, 2005.

25. Companhia de Tecnologia de Saneamento Ambiental (CETESB). Relatório de Qualidade do Ar no Estado de São Paulo 1983. São Paulo: CETESB, 1984.

26. Companhia de Tecnologia de Saneamento Ambiental (CETESB). Relatório de Qualidade do Ar no Estado de São Paulo 1997. São Paulo: CETESB,1998.

27. Companhia de Tecnologia de Saneamento Ambiental (CETESB). Relatório de Qualidade do Ar no Estado de São Paulo 1999. São Paulo: CETESB, 2000.

28. Companhia de Tecnologia de Saneamento Ambiental (CETESB). Relatório de Qualidade do Ar no Estado de São Paulo 2001. São Paulo: CETESB, 2002.

29. Companhia de Tecnologia de Saneamento Ambiental (CETESB). Relatório de Qualidade do Ar no Estado de São Paulo 2003. São Paulo: CETESB, 2004.

30. CETESB. Cetesb 25 anos. CETESB, São Paulo, 1994.

31. Companhia de Tecnologia de Saneamento Ambiental (CETESB) Boletins Diários de Qualidade do Ar. Available from: <URL: http://cetesb.sp.gov.br> [2003, november 24] [2004, september 10][2004, september 12][2004, september 15].

32. COLÓN,M.; PlEIL,J.D.; HARTLAGE,T.A.; GUARDANI,M.L.; MARTINS, M.H. Survey of volatile organic compounds associated with automotive emissions in the urban airshed of São Paulo, Brazil. Atmospheric Environment 35, 4017-31, 2001.

33. CORDIER,S.; MONFORT,C.; FILIPPINI,G.; PRESTON-MARTIN,S.; LUBIN,F.; MUELLER,B.A.; HOLLY, E.A.; PERIS-BONET,R.; McCREDIE,M.; CHOI,W.; 
LITTLE, J.; ARSLAN,A. Parental Exposure to Polycyclic Aromatic Hidrocarbons and the Risk of Childhood Brain Tumor Study.Am. J. Epidemiol 159(12): 1109-16, 2004.

34. CROSIGNANI,P.; PIFFER,S. Respiratory Tract Cancers: Lung and Mesothelioma.Epidemiol Prev. 28(2): 48-56, 2004.

35. CURY,P.M.; LICHTENFELS,A.J.F.C.; REYMÃO,M.S.F.; CONCEIÇÃO,G.M.S.; CAPELOZZI,V.L.; SALDIVA,P.H.N. Urban Levels of Air Pollution Modifies the Progression of Urethane-Induced Lung Tumours in Mice. Pathol Res Pract 196: 627$33,2000$.

36. DAGHER,Z.; GARCON,G.; GOSSET,P.; LEDOUX, F.; SURPATEANU,G.; COURCOT,D.; ABOUKAIS,A.; PUSKARIC,E.; SHIRALI,P. Pro-Inflammatory Effects of Dunkerke City Air Pollution Particulate Matter 2,5 in Human Epithelial Lung Cells (L132) in Culture. J. Appl. Toxicol. Epub ahead of print, 2005.

37. Decreto Estadual 8468/1976, SP.

38. De FLORA, S.; BALANSKY, R.M.; D'AGOSTINI,F.; IZZOTTI,A.; CAMOIRANO,A.; BENNICELLI,C.; ZHANG,Z.; WANG,Y.; LUBET,R.A.; YOU, M. Molecular Alterations and Lung Tumors in p53 Mutant Mice Exposed to Cigarette Smoke. Cancer Res. 63(4):793-800, 2003.

39. Departamento Estadual deTrânsito (DETRAN) Relatório Mensal "Estatítica da Frota de Veículos", Jan. 2005.

40. DRELA,N.; ZESKO,I.; BIERNAT,P. Cytokines Production is Altered in Mice Exposed to Airborne Suspended Matter.Immunopharmacol Immunotoxicol 24(3): 497-525, 2002.

41. EPA Qualitative and Quantitative Carcinogenic Risk Assessment, 1987.

42. EVANS,M.J.; CABRAL,L.J.; STEPHNS,L.S.J.; FREEMAN,G. Renewal of the alveolar epithelium in the rat following exposure to NO2. Am. J. Pathol., 70, 175-90, 1973. 
43. FERNANDES,M.B.; BRICKUS,L.S.; MOREIRA,J.C.; CARDOSO,J.N. Atmospheric BTX and Polyaromatic Hidrocarbons in Rio de Janeiro, Brazil. Chemosphere 47(4): 417-25, 2002.

44. FERREIRA,M.I.; PETRENKO,H.; LOBO,D.J.A.; RODRIGUES,G.S.; MOREIRA,A.; SALDIVA, P.H.N. In Situ Monitoring of the Mutagenic Effects of the Gaseous Emissions of a Solid Waste Incinerator in Metropolitan São Paulo, Brazil, Using the Tradescantia Stamen-Hair Assay. Air \& Waste Manage Assoc. 50: 1852-1856, 2000.

45. FINCH,G.L.; HOBBS,C.H.; BLAIR,L.F.; BARR,E.B.; HALM,F.F.; JARAMILLO,R.J. Effects of Subcronic Inhalation Exposure of Rats to Emissions from a Diesel Engine Burning Soybean Oil Derived Biodiesel Fuel. Inhal Toxicol 14(10): 1017-48, 2002.

46. FIRKET,J. Sur les Causes des Accidents Survenus dans la Vallée de la Meuse, lors des Brouillards de Décembre 1930. Bull. Acad. Roy. Med. Belg., 11, 683-741, 1931.

47. FLORET,N.; MAUNY,F.; CHALLIER,B.; CAHN,J.Y.; TOURNEUX,F.; VIEL,J.F. Dioxin Emissions and Soft-Tissue Sarcoma: Results of a Populational Based CaseControl Study. Rev Epidemiol Sante Publique 52(3): 213-20, 2004.

48. FUNDAÇÃO ANTÔNIO PRUDENTE www.hcanc.org.br [2003, July 23][2004, January, 25]

49. GARSHICK,E.; LADEN,F.; HART, J.E.; ROSNER, B.; SMITH, T.J.; DOCKERY, D.W.; SPELZER, F.E. Lung Cancer in Railroad Workers Exposed to Diesel Exhaust.Environ Health Persp 112(15): 1539-43, 2004.

50. GUIMARÃES,E.T.; MACCHIONE,M.; LOBO,D.J.A.; DOMINGOS,M.; SALDIVA,P.H.N. Evaluation of the Mutagenic Potential of Urban Air Pollution in São Paulo, Southeastern Brazil, Using the Tradescantia Stamen-Hair Assay. 19(6): 578-84, 2004.

51. GHIO, A.J. Biological Effects of Utah Valley Ambient Air Particles in Humans: a Review. J Aerosol Med. 17(2): 157-64, 2004.

52. GUO,J.; KAUPPINEN,T.; KYYRONEN,P.; HEIKKILA,P.; LINDBOHM,M.L.; PUKKALA,G. Risk of Esophageal, Ovarian, Testicular, Kidney and Bladder Cancers 
and Leukemia among Finnish Workers Exposed to Diesel Gasoline Engine Exhaust. Int $J$ Cancer 111(2): 286-92,2004.

53. GRAFFI,A.; VLAMYNCK,E.; HOFFMANN,F.; SCHULTZ,I. Untersuchungen uber die geschwulstauslosende wirkung verschiedener chemischer stoffe in der kombination mit crotonol. Arch Geschwulstforsch 5: 110-26,1953 (apud Reymão, 1997)

54. GROSOVSKY,A.J.; SASAKI,J.C.; AREY,J.; EASTMOND, D.A.; PARKS,K.K.; ATKINSON,M. Evaluation of the Potential Health Effects of the Atmospheric Reaction Products of Polycyclic Aromatic Hydrocarbons Res Rep Health Eff Inst 84: 1-22, 1999.

55. HARVARD REPORT ON CANCER. Cancer Causes Control, 7, 37-8, 1996.

56. HEMMINKI,K.; VEIDEBAUM,T. Environmental Pollution and Human Exposure to Polycyclic Aromatic Hydrocarbons in the East Baltic Region. Scand $J$ Work Environ Health 25(3): 33-9, 1999.

57. HOEK,G.; BRUNEKREEF,B.; GOLDBOHM,S.; FISHER,P; van den BRANDT,P.A. Association Between Mortality and Indicators of Traffic-Related Air Pollution in the Netherlands: a Cohort Study. Lancet 360:1203-09, 2002.

58. HULLEY,S.B. \& CUMMINGS, S.R. Designing Clinical Research: an epidemiological approach . Baltimore, 1988.

59. Iso 14000 Foundation www.Isol4000.com [2004, April 20, 21]

60. JADCZYK,P. Correlations Between Mutagenicity of Airborne Particles and Concentrations of Air Pollutants. (abstract) Rocz Panstw Zakl Hig 52(1): 25-33, 2001.

61. JIANG,Z.; SONG,W.; ZHOU,X.; ZHANG,Y. Study on Mouse Pulmonary Acute Injury Induced by Airborne PM 2,5. Wei Sheng Yan Jiu 33(3): 264-6, 2004. (abstract)

62. KAPPOS,A.D.; BRUCKMANN,P.; EIKMANN,T.; ENGLERT,N.; HEINRICH,U.; HOPPE-KOCH,E.; KRAUSE,G.H.; KREYLING,W.G.; RAUCHFUSS,K.; ROMBOUT,P.; SCHULZ-KLEMP,V.; THIEL,W.R.; WICHMANN,H.E. Health Effects of Particles in Ambient Air. Int J Hyg Environ Health 207(4): 399-407, 2004. 
63. KATSOUYANNI,K.; PERShagen,G. Ambient Air Pollution Exposure and Cancer. Cancer Causes Control, 8 (3), 284-91, 1997.

64. KEITH,R.L.; MILLER, Y.E.; HUDISH,T.M.; GIROD,C.E.; SOTTO-SANTIAGO,S.; FRANKL,W.A.; NEMENOFF,R.A.; $\quad$ MARCH,T.H.; $\quad$ NANA-SINKAM,S.P.; GERACI,M.W. Pulmonary Prostacyclin Synthase Overexpression Chemopreven Tobacco Smoke Lung Carcinogenesis in Mice. Cancer Res. 64(16): 5897-904, 2004.

65. KIYOHARA,C.; YOSHIMASU,K.; SHIRAKAWA,T.; HOPKIN,J.M. Genetic Polymorphisms and Environmental Risk of Lung Cancer Review. Rev Environ Health 19(1): 15-38, 2004.

66. KLEY,D.; KLEINMANN,M.; SANDERMAN,H.; KRUPA,S. Photochemical Oxidants: State of the Science. Environmental Pollution, 100, 19-42, 1999.

67. KLEINBAUM, D.G.; KUPPER, L. L.; MULlER, K. E.; NIZAM, A. Applied regression analysis and other multivariable methods. Belmont, Duxbury Press, 1998.

68. KNUDSON, A .G. Genetics of Human Cancer Ann R ev Genet 20: 231-51, 1986.

69. LAM,W.K.; WHITE,N.W.; CHAN-YEUNG,M.M. Lung Cancer Epidemiology and Risk Factors in Asia and Africa. Int J Tuberc Lung Dis. 8(9): 1045-57, 2004.

70. LEEL,Y.C.; WU,C.T.; SHIH,J.Y.; JOU,Y.S.; CHANG,Y.L. Frequent Allelic Deletion at the FHIT Locus Associated with p53 Overexpression in Squamous Cell Carcinoma Subtype of Taiwanese non-small-cell Lung Cancers. British Journal of Cancer 90: 2378-83, 2004.

71. LEWTAS,J. Airborne Carcinogens. Pharmacol Toxicol, 72 S(1), 55-63, 1993.

72. LIAO,D.; HEISS,G.; CHINCHILLI,V.M.; DUAN,Y.; FOLSOM,A.R.; LIN,H.M.; SALOMA,S. Association of Criteria Pollutants with Plasma Hemostatic/inflammatory Markers: a Population-based Study. J Expo Anal Environ Epidemiol, 2004.(publicação on line) 
73. LIN,C.A.; PEREIRA,L.A.; NISHIOKA,D.C.; CONCEIÇÃO,G.M.; BRAGA,A.L.; SALDIVA,P.H.N. Air Pollution and Neonatal Deaths in São Paulo, Brazil. Braz J Med Biol Res. 37(5): 765-70, 2004.

74. LOFT,S.; POULSEN,H.E.; VISTISEN,K.; KNUDSEN,L.E. Increased Urinary Excretion of 8-oxo-2'- Deoxyguanosine, a Biomarker of Oxidative DNA Damage, in Urban Bus Drivers. Mutat Res. 441(1): 11-9, 1999.

75. LOGAN,W.P.D. Mortality in London Fog Incident. Lancet, 1, 336-8, 1953.

76. MARTINS,M.C.; FATIGATI,F.L.; VESPOLI,T.C.; MARTINS,L.C.; PEREIRA,L.A.; MARTINS, M..A.; SALDIVA,P.H.N.; BRAGA,A.L. Influence of Socioeconomic Conditions on Air Pollution Adverse Health Effects in Elderly People: Na Analysis of Six Regions in São Paulo, Brazil. J Epidemiol Community Health 58(1): 41-6, 2004.

77. MARX,J. Many gene changes found in cancer.Science24: 1386-88, 1988.

78. MEDEIROS,P.M.; BICEGO,M.C. Investigation of Natural and Antropogenic Hidrocarbons Inputs Sediments Using Geochemical Markers. I. Santos, SP-Brazil. Mar Pollut Bull 49(9-10): 761-9, 2004.

79. MEDEIROS,P.M.; BICEGO,M.C. Investigation of Natural and Antropogenic Hidrocarbons Inputs Sediments Using Geochemical Markers. II. São Sebastião, SPBrazil. Mar Pollut Bull 49(11-12): 892-9, 2004.

80. Methods Air Sampling and analyzes- 3ed. James P. Lodge, Jr editor. Inter Societ Commity- AWMA, ACF, AIChE, APWA, ASME, AOAC, HPS, ISA- Lewis publisher, Inc.. 399-402, 1989.

81. MILLER,D.M.; BLUME,S.; BORST,M et al. Oncogenes Malignant Transformation, and Modern Medicine Am J Med Sci 300: 59-69, 1990.

82. MITELMAN,F. Catalogue of Cromossome Aberrations in Cancer, 3ed. AR Liss, New York, 1988.

83. MORETTIN, P \& BUSSAB, W. Estatística Básica. São Paulo Atual ED; 1982. 
84. MULLOLI,T.P.; PHILIPMORE,P.; MOFFAT,S.; BHOPAL,R.; FOY,C.; DUNN,C.; et al. Lung Cancer, Proximity to Industry, and Poverty in Northeast England. Environ. Health Perspec., 106 (4), 189-96, 1998.

85. NAFSTAD,P. Air Pollution and Health: What Have We Learned from Epidemiological Studies? (abstract) Tidsskr Nor Laegeforen 124(22): 2896-9, 2004.

86. NAFSTAD,P.; HAHEIM,L.L.; WISLOF,T.; GRAM, F.; OFTEDAL,B.; HOLME,I.; HJERMANN,I.; LEREN,P. Urban Air Pollution and Mortality in a Cohort of Norwegian Men. Environ Health Persp 112(5): 610-615, 2004.

87. NEUBERGER,M.;MOSHAMMER,H. Suspended Particulates and Lung Health. (abstract) Wien Klin Wochenschr 116(1): 8-12, 2004.

88. NOWELL, P.C. Cytogenetics of Tumor Progression. Cancer 65: 2172-77, 1990.

89. PEREIRA, L.A.A.; LOOMIS,D.; CONCEIÇÃO,G.M.S.; BRAGA,A.L.F.; ARCAS,R.M.; KISHI,H.S.; et al. Association Between Air Pollution and Intrauterine Mortality in São Paulo, Brazil. Environ Health Perspect., 106 (6), 325-9, 1998.

90. PEREIRA,P.A.; ANDRADE,J.B.; MIGUEL,A.H. Measurements of Semivolatile and Particulate Polycyclic Aromatic Hidrocarbons in a Bus Station and na Urban Tunnel in Salvador, Brazil. J Environ Monit 4(4): 558-61, 2002.

91. PERERA,F.P.; TANG,D.; TU,Y.H.; CRUZ,L.A.,BORJAS,M.; BERNERT,T.; WHYATT,R. Biomarkers in Maternal and Newborn Blood Indicate Heightene Fetal Susceptibility to Procarcinogenic DNA Damage. Environ Health Perspect.112(10): 1133-6, 2004

92. PESQUERO, C.R. Avaliação Ambiental de Compostos Orgânicos Aromáticos Presentes em Atmosferas Industriais. São Paulo, 1992 [Tese de Doutorado - Instituto de Química da USP].

93. PETERS,A.; von KLOT,S.; HEIER,M.; TRENTINAGLIA,I.; HORMANN,A.; WICHMANN,H.E.; LOWEL,H. Exposure to traffic and the onset of myocardial infarction. N Engl J Med 351(17): 1721-30, 2004. 
94. PETROESCHEVSKY,A.; SIMPSON,R.W.; THALIB,L.; RUTHERFORD,S. Associations Between Outdoor Air Pollution and Hospital Admissions in Brisbane, Australia. Arch Environ Health 56(1): 37-52, 2001.

95. PINHO, R.A.; BONATTO, F.;ANDRADES, M.; FROTA, M.L.Jr.; RITTER, C.; KLAMT, F.; PIZZOL, F.; ULDRICH-KULCZYNSKI, J.M.; MOREIRA, J.C. Lung Oxidative Response After Acute Coal Dust Exposure. Environ Res 96(3): 290-7, 2004.

96. PISAVERA,L.F.; BOIARKINA,A.P.; ODINTSOVA, I.N.; NEDAVNIAIA, I.O.; MARTYNOVA, LOGINOV, S.L. Risk Factors in the Development of Hemoblastosis in the Population of the Tomsk Region. Gig Sanit. (4): 24-8, 2004.

97. PLESKO, I.; OBSTNIKOVA, A.; KRAMAROVA, E. Mapping in epidemiological studies and control of cancer: experiences from Slovakia. J. Environ. Pathol. Toxicol. Oncol. 15 (2-4), 143-7, 1996.

98. PONDER,B.Gene Losses in Human Tumors. Nature 335: 400-2, 1988.

99. PONDER,B. Inherited Predisposition to Cancer. Trends Genet 6: 213-8, 1990.

100. POPE III, C.A. Adverse Health Effects of Air Pollutants in a Nonsmoking Population. Toxicology 111: 149-55, 1996.

101. POPE III, C.A.; BURNET,R.T.; THUN,M.J.; CALLE,E.E.; KREWSKI,D.; ITO,K.; TURSTON,G.D. Lung Cancer, Cardiopulmonar Mortality, and Long Term Exposure to Fine Particulate Air Pollution. JAMA, 287 (9): 1132-41, 2002.

102. PUFULETE,M.; BATTERSHILL,J.; BOOBIS,A.; FIELDER,R. Approaches to Carcinogenic Risk Assessment for Polycyclic Aromatic Hidrocarbons: a UK Perspective.Regul Toxicol Pharmacol 40(1): 54-66, 2004.

103. REED MD, GIGLIOTTI AP, MCDONALD JD, SEAGRAVE JC, SEILKOP SK, MAUDERLY Health effects of subchronic exposure to environmental levels of diesel exhaust. Inhal Toxicol. 16(4):177-93, 2004.

104. REYMÃO, M.S.F.R.; CURY,P.M.; LICHTENFELS,A.J.F.C.; LEMOS,M.; BATHLENNER,C.N.; CONCEIÇÃO,G.M.S.; et al. Urban air pollution enhances the formation of urethane induced lung tumors in mice. Environ. Res., 74, 150-8, 1997. 
105. RIBEIRO, H; ASSUNÇÃO, JV de. Efeitos das queimadas na saúde humana. Estudos Avançados, 16(44), 125-148, 2002.

106. RILEY, M.R.; BOESEWETTER, D.E.; TURNER,R.A.; KIM,A.M.; COLLIER,J.M.; HAMILTON,A. Comparison of sensitivity of three Lung Derived Cell Lines to Metals from Combustion Derived Particulate Matter. Toxicol in Vitro 19(3): 411-9, 2005.

107. RISOM,L.; DYBDAHL,M.; BORNHOLDT,J.; VOGEL,U.; WALLIN,H.; MOLLER,P.; LOFT,S. Oxidative DNA Damage and Defence Gene Expression in the Mouse Lung After Short-Term Exposure to Diesel Exhaust Particles by Inhalation. Carcinogenesis 24(11): 1847-52,2003.

108. RIVEDAL,E.; MYHRE,O.; SANNER,T.; EIDE,I. Supplemental Role of the Ames Mutation Assay and Gap Junction Intercellular Communication in Studies of Possible Carcinogenic Compounds from Diesel Exhaust Particles. Arch Toxicol 77(9): 533-42, 2003.

109. ROMIEU,I.; WEINTZENFELD,H.; FINKELMAN,J. Urban Air Pollution in Latin America and the Caribbean: Health Perspectives. World Health Stat $Q$ 43(3): 153-67, 1990.

110. RONDEAU,V.; BERHANE,K.; THOMAS,D.C. A Three-level Model for Binary Time-series Data: the Effects of a Pollution on School Absences in the Southern California Children Health Study. Stat Med, 2004.

111. ROWLEY,J.D. The Philadelphia Chromossome Translocation: A Paradigm for Understanding Leukemia. Cancer 65: 2178-2184, 1990.

112. RUSIN,M.; BUTKIEWICZL,D.; MALUSECKA,E.; ZBOREK,A.; HARASIM,J.; CZYZEWSKI,K.; BENNETT, W.P.; SHIELDS, P.G.; WESTON, A.; WELSH,J.A.; KRZYZOWSKA-GRUCA,S.; CHORAZY,M.; HARRIS, C.C. Molecular Epidemiological Study of non-small-cell Lung Cancer from na Environmental Polluted Region of Poland. British Journal of Cancer 80: 1445-52, 1999.

113. SAGER,R. Tumor Supressor Genes: The Puzzle and the Promise. Science 246: 1406-1412, 1990. 
114. SALDIVA,P.H.N.; LICHTENFELS,A.J.F.C.; PAIVA,P.S.O.; BARONE,I.A.; MARTINS,M.A.; MASSAD,E.; et al. Association Between Air Pollution and Mortality Due to Respiratory Diseases in Children in São Paulo, Brazil. A Preliminary Report . Environ. Res., 65, 218-25, 1994.

115. SALDIVA,P.H.N.; POPE,C.A.,III; SCHWARTZ,J.; DOCKERY,D.W.; LICHTENFELS,A.J.; SALGE,J.M.; et al. Air Pollution and Mortality in Elderly People: A Time-Series Study in São Paulo, Brazil . Arch. Environ. Health , 50 , 159$63,1995$.

116. SAUVIN,J.J.; DUC,T.V. Approaches to Identifying and Quantifying Polycyclic Aromatic Hydrocarbons of Molecular Weight 302 in Diesel Particules. J Sep Sci 27(12): 78-88, 2004.

117. SCHRENK,H.H.; HEIMANN,H.; CLAYTON,G.D.; GAFAFER,W.M.; WEXLER,H. Air Pollution in Donora, PA: Epidemiology of an Unusual Smog Episode of October 1948.Washington, DC: Federal Security Agency, 1949 [Public Health Bulletin 306].

118. SHARMAN,J.E.; COCKCROFT,J.R.; COOMBES,J.S. Cardiovascular Implications of Exposure to Traffic Air Pollution During Exercise. QJM 97(10): 637-43, 2004.

119. SHIMKIM,M.B. Pulmonary Tumors in Experimental Animals.Adv.CancerRes. 3: $105,1955$.

120. SHIMKIM,M.B.; WEIBURGER,J.H.; WEIBURGER,E.K.; GUBAREFF,N.; SUNTZEFF,V. Bioassay of 29 alkylating chemicals by the pulmonary-tumor response in straim “A” Mice. J.Natl.Cancer Inst. 36:915-35, 1966.

121. SIEGEL, S. Estatística não paramétrica. São Paulo: ED. McGraw-Hill do Brasil, 1981.

122. SIXTON,K.G.; JEFFRIES,H.E.; JANG,M.; KAMENS,R.M.; DOYLE,M.; VOICU,I.; JASPERS,I. Photochemical Products in Urban Mixtures Enhance Inflammatory Responses in Lung Cells.Inhal Toxicol 16 suppl 1: 107-14, 2004. 
123. SOARES,S.R.C.;

RIVERO,D.H.R.F.; CASTRO,I.; GARCIA, M.L.B.; SALDIVA,P.H.N. Urban Air Pollution Induces Micronuclei in Peripheral Erythrocytes of Mice in Vivo. Environ Res. 92: 191-6, 2003.

124. Sociedade Brasileira de Mutagenese, Carcinogenese e Teratogenese Ambiental. (SBMCT) Available from: <URL: http://sbmcta.org.br> [2004, July 20] [2004, september 7]

125. STEERENBERG,P.; VERLAAN,A.; DE KLERK,A.; BOERE,A.; LOVEREN,H.; CASSEE,F. Sensitivity to Ozone, Diesel Exhaust Particles, and Standardized Ambient Particulate Matter in Rats with a Listeria Monocytogene Induced Respiratory Infection. Inhal Toxicol 16(5): 311-7, 2004.

126. TANNENBAUM, A.; SILVERSTONE,H. Urethan (ethyl carbamate) as Multipotencial Carcinogen Cancer Res. 18: 1225-31, 1958.

127. THOMPSON,M.W.; McINNES,R.R.; WILlARD,H.F. Genética Médica $5^{\circ}$ ed. , 1993.

128. TUOMI, T.; ENGSTROM, B.; NIEMELA, R.; SVINHUFVUD, J.; REIJULA, K. Emission of ozone and organic volatiles from a selection of laser printers and photocopiers. Appl. Occup. Environ. Hyg. 15(8), 629-34, 2000.

129. TURRIO-BALDASSARI,L.; BATTISTELLI,C.L.; CONTI,L.; CREBELLI,R.; DE BERARDIS,D.; IAMICELI,A.L.; GAMBINO,M.; IANNACCONE,S. Emission Comparison of Urban Bus Engine fueled with Diesel Oil and Biodiesel Blend. Sci Total Environ 327(1-3): 147-62, 2004.

130. UENG,T.H.; WANG,H.W.; HUANG, Y.P.; HUNG,C.C. Antiestrogenic Effects of Motorcycle Exhaust Particulate in MC Human Breast Cancer Cells and Immature Female Rats. Arch Environ Contam Toxicol 46(4): 454-62, 2004.

131. VALBERG,P.A.; WATSON,A.Y. Comparative Mutagenic Dose of Ambient Diesel Engine Exhaust. Inhal Toxicol 11(3): 215-28, 1999. 
132. VINEIS,P.; FORASTIERE,F.; HOEK,G.; LIPSETT,M. Outdoor Air Pollution and Lung Cancer: Recent Epidemiologic Evidence Int J Cancer 111: 647-52, 2004.

133. VISSER, O.; van WIJEN,J.H.; van LEEUWEN,F.E. Residential Traffic Density and Cancer Incidence in Amsterdam, 1989-1997.Cancer Causes Control 15(4): 331-9, 2004.

134. VOL'FSON,N.I. The Genesis of Experimental Granulosa Cell Tumors of the Ovary. Vopr Onkol 22(3): 68-75,1976.

135. WEINBERG, R.A. The Genetic Basis of Cancer. Arch Surg 125: 257-60, 1990.

136. WHINCUP,P.H.; GILG,J.A.; EMBERSON,J.R.; JARVIS,M.J.; FEYERABEND,C.; BRYAN-WALKER,M.; COOK,D.G. Passive Smoke and Risk of Coronary Heart Disease and Stroke: Prospective Study with Cotinine Measurement. BMJ 329(7459): 200-5, 2004.

137. WITSCH, H.; ESPIRITU, I.; UYEMINAMI, D.; SUFFIA, M.; PINKERTON, K.E. Lung Tumor Response in Strain a Mice Exposed to Tobacco Smoke: Some Dose-Effect Relationships. Inhal Toxicol.16 (1): 27-32, 2004.

138. WOLFF,M.S.; WESTON,A. Breast Cancer Risk and Environmental Exposures .Environ. Health Perspec., 105 S(4), 891-6, 1997.

139. World Health Organization (WHO) Principles and Methods for Evaluating the Toxicity of Chemicals/ Part I., 1978.

140. World Health Organization / International Agency for Research on Cancer (WHO/LARC)IARC monographs programme on the evaluation of carcinogenic risks to humans. Available from: <URL: http://monographs.iarc.fr>) [2002, may 17] [2004, january 25]

141. YANG,H.M.; BUTTERWORTH,L.; MUNSON,A.E.; MEADE,B.J. Respiratory Exposure to Diesel Exhaust Particles Decreases the Spleen IgM Response to a Ceeldependent Antigen in Female B6C3F1 Mice. Toxicol Sci 71(2): 207-16, 2003.

142. ZANOBETTI,A.; CANNER,M.J.; STONE,P.H.; SCHWARTZ,J.; SHER,D.; EAGAN-BENGS,E.; GATES,K.A.; HARTLEY,L.H.; SUH,H.; GOLD,D.R. Ambient 
Pollution and Blood Pressure in Cardiac Rehabilitation Patients. Circulation 110(15): 2184-9, 2004.

143. ZHANG,J.; LIU,Y.; SHI,J.; LARSON,D.F.; WATSON,R.R. Side -stream Cigarette Smoke Induces Dose-Response in Systemic Inflammatory Cytokine Production and Oxidative Stress. Exp.Biol Med 227(9): 823-9, 2002.

144. ZHAO,X.; WAN,Z.; ZHU,H.; CHEN,R. The Carcinogenic Potential of Extractable Organic Matter from Urban Airborne Particles in Shangai, China. Mutat Res. 540(1): 107-17,2003.

145. ZHU,B.Q.;HEESCHEN,C.; SIEVERS,R.E.; KARLINER,J.S.; PARMLEY,WW.; GLANTZ,S.; COOKE,J.P. Second Hand Smoke Stimulates Tumor Angiogenesis and Growth. Cancer Cell 4(3): 191-6, 2003. 